(C) 2004 American Chemical Society, J. Am. Chem. Soc., Driver ja0306563 Supporting Info Page 1

Supporting Information: Tom G. Driver and K. A. Woerpel

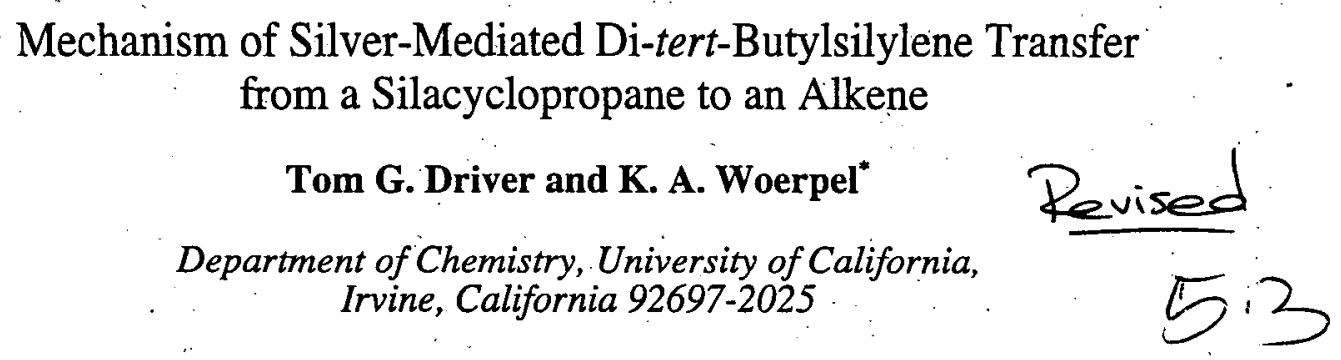

Supporting Information

\title{
Contents:
}

I. Construction of silacyclopropanes.....................................

II. Construction of silver phosphine complexes..........................s

III. Optimization of silver salt for kinetic study ..............................s 5

IV. Determination of kinetic order......................................s 8

V. Observation and analysis of the behavior of silylsilver complex 8..........s-14

VI. Analysis of possible mechanisms.......................................s 16

VII. Competition reactions between substituted styrenes........................s-19

VIII. Competition experiments between cyclic and acyclic alkenes..............s $s$-28

IX: Determination of activation parameters in $\mathrm{CD}_{2} \mathrm{Cl}_{2}$ and toluene- $d_{8} \ldots \ldots \ldots \ldots . . .29$

X. References..........................................................

XI. Crystallographic data................................................s 34

XII. Spectra of NMR and IR monitored reactions...........................s 42

General. ${ }^{1} \mathrm{H},{ }^{13} \mathrm{C},{ }^{29} \mathrm{Si}$ NMR spectra were recorded using Bruker DRX 500 or DRX 400 spectrometers. The data are reported as follows: chemical shift in ppm from internal tetramethylsilane on the $\delta$ scale, multiplicity ( $b r=$ broad, $s=$ singlet, $d=$ doublet, $t=$ triplet, $q=$ quartet, $m=$ multiplet $)$, coupling constants $(\mathrm{Hz})$, and integration. ${ }^{31} \mathrm{P}$ NMR spectra were recorded using Bruker. DRX 500 or DRX 400 spectrometers. The chemical shift in ppm was reported from an external $85 \% \mathrm{H}_{3} \mathrm{PO}_{4}$ standard on the $\delta$ scale. High resolution mass spectra were acquired on a VG Analytical 7070E or Fisons Autospec spectrometer, and were obtained by peak matching. All experiments were carried out under an atmosphere of nitrogen or argon in glassware that had been dried at $130^{\circ} \mathrm{C}$ for $15 \mathrm{~h}$. Unless otherwise noted, all reagents were commercially obtained and, where appropriate, purified prior to use. Toluene, THF, $\mathrm{Et}_{2} \mathrm{O}$, and $\mathrm{CH}_{2} \mathrm{Cl}_{2}$ were dried by filtration through alumina according to the procedure of Grubbs. ${ }^{1}$ Toluene- $d_{8}$ was distilled from $\mathrm{CaH}_{2}$ and degassed before use. Deuterated methylene chloride was vacuum transferred from activated molecular sieves. Silacyclopropanes and silver salts were stored in an Innovative Technologies nitrogen atmosphere dry box. 
(C) 2004 American Chemical Society, J. Am. Chem. Soc., Driver ja0306563 Supporting Info Page 2

Supporting Information: Tom G. Driver and K. A. Woerpel

General Comments Concerning the Procedure. The apparatuses (volumetric flasks and NMR tubes) were washed with a solution of $2: 1 \mathrm{HCl}(12 \mathrm{~N}): \mathrm{HNO}_{3}(16 \mathrm{~N})$, rinsed with water and acetone, washed with ammonium hydroxide, and rinsed with water and acetone. The NMR tubes were dried at $130^{\circ} \mathrm{C}$. Each experiment was set up in the nitrogen atmosphere dry box and was carried out in triplicate (three at a time). The reagents were added, dropwise, to a cold solution of cyclohexene silacyclopropane 1 . After agitation, the NMR tube containing the reaction mixture was placed in a cold (below the temperature for kinetic analysis) NMR spectrometer. The reaction mixture was warmed to the desired temperature in the NMR spectrometer. The reaction progress over the first half-life (or, when appropriate; five half-lives) was monitored periodically using ${ }^{1} \mathrm{H}$ NMR spectroșcopy. The concentrations of the reactants and products were obtained through comparison of the area of the standard $\left(\mathrm{PhSiMe}_{3}\right.$ peak at $0.19 \mathrm{ppm}$, area $\left.=1.0000\right)$ and the area of the $t-\mathrm{Bu}$ peaks of the silacyclopropanes 1 and $3(1, \delta 1.00$ and $1.19 \mathrm{ppm} ; 3, \delta 1.06$ and $0.83 \mathrm{ppm})$. The data obtained was fit to the best straight line using a least-squares program.

\section{Construction of silacyclopropanes}

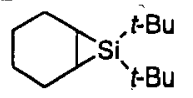

1

Cyclohexene di-tert-butylsilacyclopropane (1). To a cooled $\left(\begin{array}{lll}-78 & \mathrm{C}\end{array}\right)$ slurry of lithium and sodium powder $\left(6.0 \mathrm{~g}, 84 \mathrm{mmol} \mathrm{Li}, 1.8 \mathrm{~g}, 78 \mathrm{mmol} \mathrm{Na}^{0}\right.$, obtained by washing $20 \mathrm{~g}$ of a $30 \%$ lithium dispersion and $6.0 \mathrm{~g}$ of a $30-35 \%$ sodium dispersion in paraffin with $5 \times 50 \mathrm{~mL}$ of hexanes) in $88.0 \mathrm{~mL}$ of THF was added cyclohexene $(86.0 \mathrm{~mL}, 844 \mathrm{mmol})$ and di-tert-butyldichlorosilane $(53.0 \mathrm{~mL}, 249 \mathrm{mmol})$. After the slurry was allowed to warm to $25 \mathrm{C}$ over $36 \mathrm{~h}$, the reaction mixture was concentrated in vacuo, and the resulting residue was extracted with hexanes $(5 \times 50 \mathrm{~mL})$. The supernatant was filtered through a short column of Celite under nitrogen, and concentrated in vacuo to give a viscous yellow oil. Purification by bulb-to-bulb distillation $\left(100-110^{\circ} \mathrm{C} / 0.05 \mathrm{~mm} \mathrm{Hg}\right)$ yielded the product as a clear oil $(45.7 \mathrm{~g}, 82 \%):{ }^{1} \mathrm{H} \mathrm{NMR}\left(500 \mathrm{MHz}, \mathrm{C}_{6} \mathrm{D}_{6}\right) \delta 1.87$ $(\mathrm{m}, 2 \mathrm{H}), 1.74(\mathrm{~m}, 4 \mathrm{H}), 1.56(\mathrm{~m}, 2 \mathrm{H}), 1.20(\mathrm{br} \mathrm{s}, 9 \mathrm{H}), 1.04(\mathrm{br} \mathrm{s}, 11 \mathrm{H}) ;{ }^{13} \mathrm{C} \mathrm{NMR}\left(125 \mathrm{MHz}, \mathrm{C}_{6} \mathrm{D}_{6}\right) \delta 31.9,30.3$, 23.5, 19.9, 19.0, 18.5, 12.9. The spectral data matched that reported by Boudjouk and co-workers. ${ }^{2.3}$

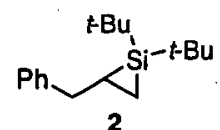

Benzyl di-tert-butylsilacyclopropane (2). To a solution of cyclohexene silacyclopropane 1 (2.61 g, 11.6 $\mathrm{mmol}$ ) in $3 \mathrm{~mL}$ of toluene (contained in a $25 \mathrm{~mL}$ valved tube) was added allylbenzene ( $2.6 \mathrm{~mL}, 19.6 \mathrm{mmol}$ ). The solution was degassed and heated to $86^{\circ} \mathrm{C}$. After $16 \mathrm{~h}$, the volatile components of the reaction mixture were removed in vacuo to afford 2 as a clear oil $(2.75 \mathrm{~g}, 91 \%)$ : ${ }^{1} \mathrm{H}$ NMR $\left(500 \mathrm{MHz}, \mathrm{C}_{6} \mathrm{D}_{6}\right) \delta .7 .32(\mathrm{~m}, 2 \mathrm{H}), 7.23$ $(\mathrm{m}, 2 \mathrm{H}), 7.11(\mathrm{~m}, 1 \mathrm{H}), 3.03(\mathrm{dd}, J=9.2,15.2 \mathrm{~Hz}, 1 \mathrm{H}), 2.97(\mathrm{dd}, J=7.6,15.2 \mathrm{~Hz}, 1 \mathrm{H}), 1.15(\mathrm{~m}, 1 \mathrm{H}), 1.09(\mathrm{~s}$, $9 \mathrm{H}), 1.00(\mathrm{~s}, 9 \mathrm{H}), 0.88(\mathrm{dd}, J=10.9,12.0 \mathrm{~Hz}, 1 \mathrm{H}), 0.35(\mathrm{dd}, J=8.9,10.9 \mathrm{~Hz}, 1 \mathrm{H}) ;{ }^{13} \mathrm{C} \mathrm{NMR}\left(125 \mathrm{MHz}, \mathrm{C}_{6} \mathrm{D}_{6}\right)$ $\delta 145.2,128.9,128.7,126.2,38.4,31.1,30.2,19.4,18.6,14.9,4.3 ;{ }^{29} \mathrm{Si} \mathrm{NMR}\left(99.3 \mathrm{MHz}, \mathrm{C}_{6} \mathrm{D}_{6}\right) \delta-48.9$; HRMS (EI) $m / z$ calcd for $\mathrm{C}_{17} \mathrm{H}_{28} \mathrm{Si}(\mathrm{M})^{+} 260.1960$, found 260.1957 .

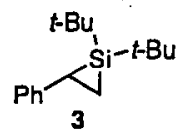

Styrene di-tert-butylsilacyclopropane (3). To a solution of cyclohexene silacyclopropane 1 (1.81 $\mathrm{g}, 8.06$ $\mathrm{mmol}$ ) in $8 \mathrm{~mL}$ of toluene (contained in a $25 \mathrm{~mL}$ valved tube) was added styrene $(1.25 \mathrm{~mL}, 13.2 \mathrm{mmol})$. The 
(C) 2004 American Chemical Society, J. Am. Chem. Soc., Driver ja0306563 Supporting Info Page 3

Supporting Information: Tom G. Driver and K. A. Woerpel

$s-3$

solution was degassed and heated to $86^{\circ} \mathrm{C}$. After $16 \mathrm{~h}$, the volatile components of the reaction mixture were removed in vacuo to afford 3 as a clear oil $(2.00 \mathrm{~g}, 100 \%):{ }^{1} \mathrm{H}$ NMR $\left(500 \mathrm{MHz}, \mathrm{C}_{6} \mathrm{D}_{6}\right) \delta 7.31$ (dd, $J=8.3,1.1$ $\mathrm{Hz}, 2 \mathrm{H}), 7.19(\mathrm{t}, J=7.5 \mathrm{~Hz}, 2 \mathrm{H}), 7.01(\mathrm{~m}, 1 \mathrm{H}), 2.40(\mathrm{t}, J=10.7 \mathrm{~Hz}, 1 \mathrm{H}), 1.05-1.10(\mathrm{~m}, 1 \mathrm{H}), 1.04(\mathrm{~s}, 9 \mathrm{H})$, $0.87(\mathrm{~s}, 9 \mathrm{H}) ;{ }^{13} \mathrm{C}$ NMR $\left(125 \mathrm{MHz}, \mathrm{C}_{6} \mathrm{D}_{6}\right) \delta 143.8,128.9,128.7,124.5,30.5,30.1,20.00,19.95,18.9,0.8 ;{ }^{29} \mathrm{Si}$ NMR (99.3 MHz, $\mathrm{C}_{6} \mathrm{D}_{6}$ ) $\delta-50.1$; HRMS (EI) $\mathrm{m} / z$ calcd for $\mathrm{C}_{16} \mathrm{H}_{26} \mathrm{Si}(\mathrm{M})^{+} 246.1804$, found 246.1802 .

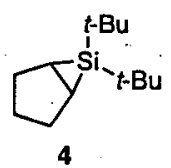

Cyclopentene di-tert-butylsilacyclopropane (4). To a cooled $\left(\begin{array}{lll}-78 & \mathrm{C}\end{array}\right)$ slurry of lithium powder $(0.30 \mathrm{~g}, 39$ mmol obtained by washing $1.0 \mathrm{~g}$ of a $30 \%$ lithium dispersion with $2 \times 10 \mathrm{~mL}$ and $2 \times 5 \mathrm{~mL}$ of hexanes) in 6.0 $\mathrm{mL}$ THF was added cyclopentene $(1.00 \mathrm{~mL}, 0.0114 \mathrm{mmol})$ and di-tert-butyldichlorosilane $(2.8 \mathrm{~mL}, 0.0131$ mmol). After the slurry was allowed to warm to 25 C over $20 \mathrm{~h}$, the reaction mixture was concentrated in vacuo, and the resulting residue was extracted with hexanes $(5 \times 10 \mathrm{~mL})$. The supernatant was filtered through a short column of Celite under nitrogen, and concentrated in vacuo to give a viscous yellow oil which was purified by bulb-to-bulb distillation $\left(80-100{ }^{\circ} \mathrm{C} / 0.05 \mathrm{mmHg}\right)$ to give the product $(1.31 \mathrm{~g}, 47 \%)$ a clear oil: ${ }^{1} \mathrm{H}$ NMR $\left(500 \mathrm{MHz}, \mathrm{C}_{6} \mathrm{D}_{6}\right) \delta 2.18(\mathrm{~m}, 2 \mathrm{H}), 1.95(\mathrm{~m}, 4 \mathrm{H}), 1.44(\mathrm{~m}, 2 \mathrm{H}), 1.13(\mathrm{~s}, 9 \mathrm{H}), 1.01(\mathrm{~s}, 9 \mathrm{H}) ;{ }^{13} \mathrm{C} \mathrm{NMR}(125$ $\left.\mathrm{MHz}, \mathrm{C}_{6} \mathrm{D}_{6}\right) \delta 34.0,31.4,29.8,27.8,21.4,21.2,19.3 ;{ }^{29} \mathrm{Si} \mathrm{NMR}\left(99.3 \mathrm{MHz}, \mathrm{C}_{6} \mathrm{D}_{6}\right) \delta-39.5$. Spectral data matched that reported by Weidenbruch and co-workers. ${ }^{4}$

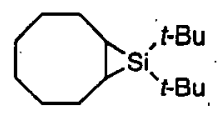

5

Cyclooctene di-tert-butylsilacyclopropane (5). The procedure employed for the synthesis of 4 was followed with cyclooctene to obtain $\mathbf{5}$ as a viscous yellow oil which was purified by bulb-to-bulb distillation (100-110 ${ }^{\circ} \mathrm{C} / 0.05 \mathrm{mmHg}$ ) to give the product as a clear oil $(1.79 \mathrm{~g}$; $56 \%):{ }^{1} \mathrm{H}$ NMR $\left(500 \mathrm{MHz}, \mathrm{C}_{6} \mathrm{D}_{6}\right) \delta 2.01(\mathrm{~m}, 2 \mathrm{H}), 1.73$ $(\mathrm{m}, 6 \mathrm{H}), 1.42(\mathrm{~m}, 4 \mathrm{H}), 1.16(\mathrm{~s}, 9 \mathrm{H}), 1.04(\mathrm{~s}, 9 \mathrm{H}), 0.92(\mathrm{~m}, 2 \mathrm{H}) ;{ }^{13} \mathrm{C} \mathrm{NMR}\left(125 \mathrm{MHz}, \mathrm{C}_{6} \mathrm{D}_{6}\right) \delta 33.8,31.6,30.0$, 26.6, 24.4, 20.5, 18.6, 18.5; ${ }^{29} \mathrm{Si} \operatorname{NMR}\left(99.3 \mathrm{MHz}, \mathrm{C}_{6} \mathrm{D}_{6}\right) \delta-53.9$.

\section{Construction of Phosphine Silver Complexes}

$$
\left[\left(\mathrm{Ph}_{3} \mathrm{P}\right)_{2} \mathrm{AgOTf}\right]_{2}
$$

Bistriphenylphosphine silver trifluoromethansulfonate. To a rapidly stirring solution of AgOTf (1.00 g, $3.91 \mathrm{mmol})$ in $200 \mathrm{~mL}$ of $\mathrm{Et}_{2} \mathrm{O}$ was added a solution containing triphenylphosphine $(2.08 \mathrm{~g}, 7.93 \mathrm{mmol})$. After $20 \mathrm{~min}$, the resultant white mixture was cooled to $-20^{\circ} \mathrm{C}$. After $30 \mathrm{~min}$, the white precipitate was filtered and washed with $4 \times 5 \mathrm{~mL}$ of $\mathrm{Et}_{2} \mathrm{O}$. Residual $\mathrm{Et}_{2} \mathrm{O}$ was removed in vacuo, producing a chalky white solid $(5.50 \mathrm{~g}$, $90 \%)$. Crystallization using slow diffusion $\left(\mathrm{CH}_{2} \mathrm{Cl}_{2} /\right.$ hexanes $)$ afforded crystals suitable for $\mathrm{X}$-ray crystallographic analysis (refer to s-35 for crystallographic data summary): mp $208{ }^{\circ} \mathrm{C}$; ${ }^{31} \mathrm{P}$ NMR $(162 \mathrm{MHz}$, $\left.\mathrm{CDCl}_{3}\right) \delta 8-16 \mathrm{ppm}$ (br s); ${ }^{31} \mathrm{P}$ NMR $\left(202 \mathrm{MHz}, \mathrm{CD}_{2} \mathrm{Cl}_{2},-30{ }^{\circ} \mathrm{C}\right) \delta 12.4\left(\mathrm{~d}, J=487.4 \mathrm{~Hz}{ }^{107} \mathrm{Ag}{ }^{31} \mathrm{P}\right), 12.4(\mathrm{~d}, J$ $\left.=560.0 \mathrm{~Hz}{ }^{109} \mathrm{Ag}^{31} \mathrm{P}\right)$; Spectral data matched that reported by Laguna and co-workers. ${ }^{5} \mathrm{IR}$ (KBr pellet) 1479 , $1435,1289\left(\mathrm{v}\left[\mathrm{SO}_{3}(\mathrm{E})\right]\right), 1243\left(\mathrm{v}\left[\mathrm{CF}_{3}\left(\mathrm{~A}_{1}\right)\right], 1159\left(\mathrm{v}\left[\mathrm{CF}_{3}(\mathrm{E})\right]\right), 1096\left(\mathrm{v}\left[\mathrm{SO}_{3}\left(\mathrm{~A}_{1}\right)\right]\right) \mathrm{cm}^{-1}\right.$; IR $(0.32 \mathrm{M}$ solution in $\mathrm{CH}_{2} \mathrm{Cl}_{2}$ refer to s-43) $3065,1482,1436,1293,1239,1166,1096 \mathrm{~cm}^{-1}$; LRMS (electrospray) $m / z$ calcd for $\mathrm{C}_{36} \mathrm{H}_{30} \mathrm{AgP}_{2}\left(\mathrm{M}-\mathrm{O}_{3} \mathrm{SCF}_{3}\right)^{+} 631$ and 633 , found 631 and 633 . 
(C) 2004 American Chemical Society, J. Am. Chem. Soc., Driver ja0306563 Supporting Info Page 4

Supporting Information: Tom G. Driver and K. A. Woerpel

$s-4$

Variable temperature ${ }^{31} \mathrm{P}$ NMR Spectroscopy (Figure s1) ${ }^{31} \mathrm{P}$ NMR spectroscopy was used to analyze a 9.17 $\times 10^{-5} \mathrm{M}$ solution of $\left[\left(\mathrm{Ph}_{3} \mathrm{P}\right)_{2} \mathrm{AgOTf}\right]_{2}$ in $\mathrm{CD}_{2} \mathrm{Cl}_{2}$ at different temperatures (Figure s1).

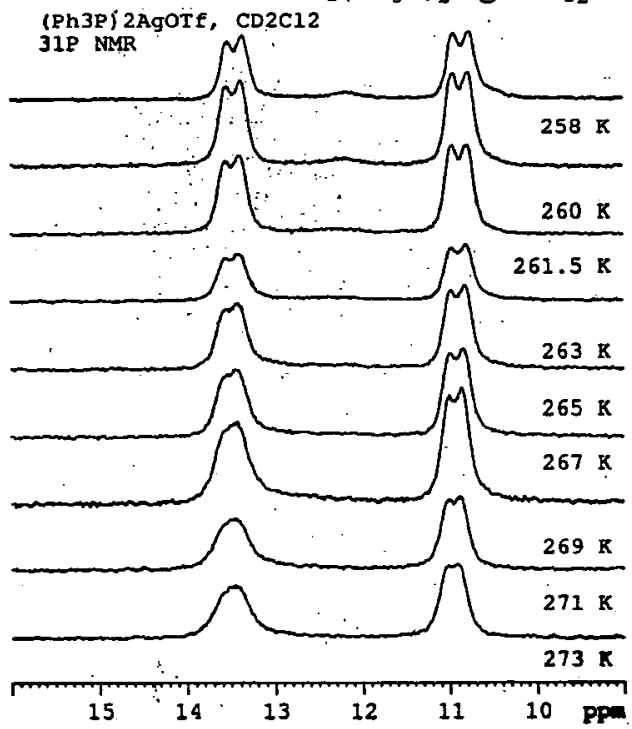

Figure s1. Variable temperature ${ }^{31} \mathrm{P}$ NMR spectroscopic experiments on $\left[\left(\mathrm{Ph}_{3} \mathrm{P}\right)_{2} \mathrm{AgOTf}\right]_{2}$

$\left\{\left[\left(\text { para- } \mathrm{MeOC}_{4} \mathrm{H}_{4}\right)_{3} \mathrm{P}\right]_{2} \mathrm{AgOTf}\right\}_{\mathrm{n}^{*}}$ To a rapidly stirring solution of AgOTf $(0.101 \mathrm{~g}, 0.389 \mathrm{mmol})$ in $2.5 \mathrm{~mL}$ toluene was added a solution of $\left(\mathrm{MeOC}_{6} \mathrm{H}_{4}\right)_{3} \mathrm{P}(0.280 \mathrm{~g}, 0.795 \mathrm{mmol})$ in $3 \mathrm{~mL}$ of toluene. After $30 \mathrm{~min}$, the reaction mixture was cooled to $-20^{\circ} \mathrm{C}$. After $15 \mathrm{~h}, 3 \mathrm{~mL}$ of cold $\left(-20^{\circ} \mathrm{C}\right)$ hexanes was added until a cloud point was reached. Filtration afforded the product as a light yellow oil. Removal of the volatile solvents in vacuo resulted in the isolation of the silver phosphine complex as a foam $(0.363 \mathrm{~g}, 97 \%)$ : ${ }^{1} \mathrm{H}$ NMR $(400 \mathrm{MHz}$, $\mathrm{CDCl}_{3}$ ) $\delta 7.33$ (br s, 2H), $6.87(\mathrm{~d}, J=10.8 \mathrm{~Hz}, 2 \mathrm{H}), 3.81(\mathrm{~s}, 3 \mathrm{H}) ;{ }^{31} \mathrm{P} \mathrm{NMR}\left(162 \mathrm{MHz}, \mathrm{CDCl}_{3}\right) \delta 8-13$ (br s); LRMS (electrospray) $m / z$ calcd for $\mathrm{C}_{42} \mathrm{H}_{42} \mathrm{O}_{3} \mathrm{AgP}_{2}\left(\mathrm{M}-\mathrm{O}_{3} \mathrm{SCF}_{3}\right)^{+} 811$ and 813 , found 811 and 813 .

$\left\{\left[\left(\mathrm{F}_{5} \mathrm{C}_{6}\right)_{3} \mathbf{P}\right]_{2} \mathrm{AgOTf}\right\}_{\mathrm{n}} \cdot \mathrm{PhCH}_{3}$. To a rapidly stirring solution of AgOTf $(0.060 \mathrm{~g}, 0.234 \mathrm{mmol})$ in $0.750 \mathrm{~mL}$ of toluene was added a solution of $\left(\mathrm{C}_{6} \mathrm{~F}_{5}\right)_{3} \mathrm{P}(0.251 \mathrm{~g}, 0.472 \mathrm{mmol})$ in $0.500 \mathrm{~mL}$ of toluene. The resulting cloudy solution was cooled to $-20^{\circ} \mathrm{C}$. After $15 \mathrm{~h}, 3 \mathrm{~mL}$ of cold $\left(-20^{\circ} \mathrm{C}\right)$ hexanes was added to induce precipitation. Filtration followed by removal of the volatile solvents in vacuo afforded the product as a white solid $(0.325 \mathrm{~g}$, 98\%): $\mathrm{mp} 167-168^{\circ} \mathrm{C} ;{ }^{1} \mathrm{H}$ NMR (400 MHz, $\left.\mathrm{CDCl}_{3}\right) \delta 7.24-7.28(\mathrm{~m}, 2 \mathrm{H}), 7.16-7.18(\mathrm{~m}, 3 \mathrm{H}), 2.36(\mathrm{~s}, 3 \mathrm{H})$; ${ }^{19} \mathrm{~F} \mathrm{NMR}\left(376 \mathrm{MHz}, \mathrm{CDCl}_{3}\right.$ ) $\delta-78.2(\mathrm{~s}, 1 \mathrm{~F}),-129.6(\mathrm{dd}, J=37.6,18.8 \mathrm{~Hz}, 2 \mathrm{~F}),-145.8(\mathrm{t}, J=22.6 \mathrm{~Hz}, 1 \mathrm{~F})$, -158.9 (dd, $J=22.6,18.8 \mathrm{~Hz}, 2 \mathrm{~F}$ ); ${ }^{31} \mathrm{P} \mathrm{NMR}\left(162 \mathrm{MHz}, \mathrm{CDCl}_{3}\right.$ ) $\delta-60.7$ (s), -72.09 (quintet, $J=161 \mathrm{~Hz}$ ); LRMS (electrospray) $m / z$ calcd for $\mathrm{C}_{36} \mathrm{AgF}_{30} \mathrm{P}_{2}\left(\mathrm{M}-\mathrm{O}_{3} \mathrm{SCF}_{3} \text { and } \mathrm{PhCH}_{3}\right)^{+} 1170$, found 1171 .

$\left[\left(\mathrm{Cy}_{3} \mathbf{P}\right)_{2} \mathbf{A g O T f}\right]_{\mathrm{n}^{-}}$The procedure for $\left\{\left[\left(\mathrm{F}_{5} \mathrm{C}_{6}\right)_{3} \mathrm{P}\right]_{2} \mathrm{AgOTf}\right\}_{\mathrm{n}} \cdot \mathrm{PhCH}_{3}$ was followed for $\left[\left(\mathrm{Cy}_{3} \mathrm{P}\right)_{2} \mathrm{AgOTf}\right]_{\mathrm{n}}$ to afford the product as a white solid $(0.220 \mathrm{~g} ; 71 \%)$ : $\mathrm{mp} 187-188{ }^{\circ} \mathrm{C} ;{ }^{1} \mathrm{H} \mathrm{NMR}\left(400 \mathrm{MHz}, \mathrm{CDCl}_{3}\right) \delta 1.65-2.1$ (m, $20 \mathrm{H}), 1.1-1.43(\mathrm{~m}, 16 \mathrm{H}) ;{ }^{31} \mathrm{P}$ NMR $\left(162 \mathrm{MHz}, \mathrm{CDCl}_{3}\right) \delta 33.55\left(\mathrm{~d}, J=463 \mathrm{~Hz},{ }^{107} \mathrm{Ag}_{-}{ }^{31} \mathrm{P}\right), 33.55(\mathrm{~d}, J=534$. $\left.\mathrm{Hz},{ }^{109} \mathrm{Ag}-{ }^{31} \mathrm{P}\right)$; ERMS (electrospray) $m / z$ calcd for $\mathrm{C}_{36} \mathrm{H}_{66} \mathrm{AgP}_{2}\left(\mathrm{M}-\mathrm{O}_{3} \mathrm{SCF}_{3}\right)^{+} 667$ and 669 , found 667 and 669.

$\left[\left(t-\mathrm{Bu}_{3} \mathrm{P}\right)_{2} \mathrm{AgOTf}\right]_{\mathrm{n}^{*}}$. The procedure for $\left\{\left[\left(\mathrm{F}_{5} \mathrm{C}_{6}\right)_{3} \mathrm{P}\right]_{2} \mathrm{AgOTf}\right\}_{\mathrm{n}} \cdot \mathrm{PhCH}_{3}$ was followed for $\left[\left(t-\mathrm{Bu}_{3} \mathrm{P}\right)_{2} \mathrm{AgOTf}\right]_{\mathrm{n}}$ to afford the product as a white solid $(0.210 \mathrm{~g}, 81 \%)$ : $\mathrm{mp} 237-238^{\circ} \mathrm{C} ;{ }^{1} \mathrm{H} \mathrm{NMR}\left(400 \mathrm{MHz}, \mathrm{CDCl}_{3}\right) \delta 1.51(\mathrm{~m}$, 
(C) 2004 American Chemical Society, J. Am. Chem. Soc., Driver ja0306563 Supporting Info Page 5

Supporting Information: Tom G. Driver and K. A. Woerpel

54H); $\left.{ }^{31} \mathrm{P} \mathrm{NMR} \mathrm{(162} \mathrm{MHz,} \mathrm{CDCl}_{3}\right) \delta 79.0$ (br d, $J=452 \mathrm{~Hz}$, average Ag-P); ERMS (electrospray) $m / z$ calcd for $\mathrm{C}_{24} \mathrm{H}_{54} \mathrm{AgP}_{2}\left(\mathrm{M}-\mathrm{O}_{3} \mathrm{SCF}_{3}\right)^{+} .511$ and 513 , found 511 and 513 .

\section{Optimization of silver salt for kinetic study}

\section{A. Variation of Silver(I) counterion}

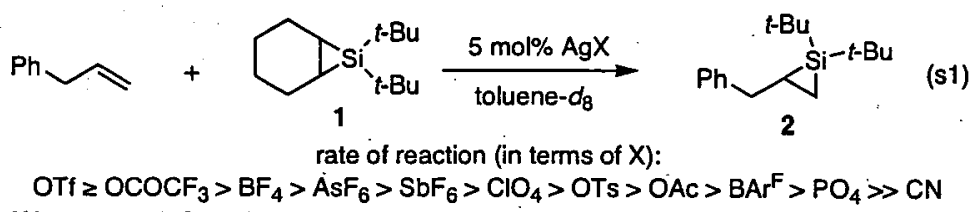

The general procedure is illustrated for the reaction of cyclohexene silacyclopropane 1 with excess allylbenzene in the presence of $5 \mathrm{~mol} \%$ AgOTf (eq s1). To a cool $\left(-78^{\circ} \mathrm{C}\right)$ solution of AgOTf $(0.0010 \mathrm{~g}, 0.0044 \mathrm{mmol})$ and allylbenzene $\left(0.180 \mathrm{~mL}, 1.34 \mathrm{mmol}\right.$ ) in $0.350 \mathrm{~mL}$ of a $0.023246 \mathrm{M}$ solution of $\mathrm{PhSiMe}_{3}$ in toluene- $d_{8}$ (contained in a thin wall NMR tube), was added a solution of cyclohexene silacyclopropane $1(0.0200 \mathrm{~g}, 0.0891 \mathrm{mmol})$ in $0.200 \mathrm{~mL}$ of a $0.023246 \mathrm{M}$ solution of $\mathrm{PhSiMe}_{3}$ in toluene- $d_{8}$. After thermal equilibration to $-78^{\circ} \mathrm{C}$, the resulting solution was shaken five times. The reaction mixture was re-cooled to $-78{ }^{\circ} \mathrm{C}$, and then it was placed in a cool $\left(-60^{\circ} \mathrm{C}\right) \mathrm{NMR}$ spectrometer. An initial ${ }^{\mathrm{l}} \mathrm{H}$ NMR spectrum was obtained, and the temperature of the experiment was regulated to $-35^{\circ} \mathrm{C}$. Periodically the reaction progress was measured relative to the internal standard of $\mathrm{PhSiMe}{ }_{3}$ using ${ }^{1} \mathrm{H}$ NMR spectroscopy. The data is summarized in Table $\mathrm{s} 1$.

Table (s1). Determination of relative reactivity of $\mathrm{AgX}$ catalysts

\begin{tabular}{|c|c|c|c|c|}
\hline$x$ & ${ }^{\circ} \mathrm{C}$ & $\mathrm{k}_{\mathrm{obs}}\left(\mathrm{s}^{-1}\right)$ & $k_{\text {init }}\left(M \cdot s^{-1}\right)$ & $t_{1 / 2}$ \\
\hline -OTf & -35 & $4.06 \times 10^{-4}$ & & $29 \min$ \\
\hline$-\mathrm{O}_{2} \mathrm{CCF}_{3}$ & -35 & $5.97 \times 10^{-4}$ & & $30 \mathrm{~min}$ \\
\hline$-\mathrm{BF}_{4}$ & -35 & $2: 79 \times 10^{-4}$ & & $1 \mathrm{~h}(20 \mathrm{~min})^{\mathrm{a}}$ \\
\hline$-\mathrm{PF}_{6}$ & -25 & $1.61 \times 10^{-3}$ & . & $5 \mathrm{~min}$ \\
\hline $\mathrm{AsF}_{6}$ & -25 & $4.05 \times 10^{-4}$ & & $14 \mathrm{~min}$ \\
\hline$-\mathrm{SbF}_{6}$ & -25 & & $1.08 \times 10^{-5}$ & $\sim 1 \mathrm{~h}$ \\
\hline$-\mathrm{ClO}_{4}$ & -15 & $2.42 \times 10^{-4}$ & & $26 \mathrm{~min}$ \\
\hline -OTs & -5 & $\cdot$ & $2.02 \times 10^{-5}$ & $40 \mathrm{~min}$ \\
\hline${ }^{-O A C}$ & r.t. & n.a. & & $\sim 90 \min ^{b}$ \\
\hline -BAr ${ }^{F}$ & r.t. & n.a & & $\sim 4 \mathrm{~h}^{\mathrm{b}}$ \\
\hline$-\mathrm{PO}_{4}$ & r.t. & n.a. & & $\sim 8 \mathrm{~h}^{\mathrm{b}}$ \\
\hline${ }^{-\mathrm{CN}}$ & r.t. & & & n.r. \\
\hline
\end{tabular}

${ }^{\mathrm{a} A}$ one hour induction period was observed before reaction. ${ }^{\mathrm{b}} \mathrm{Half}$ life was estimated from time necessary for the reaction to go to $95 \%$ completion.

\section{B. Addition of ancillary phosphine ligand}

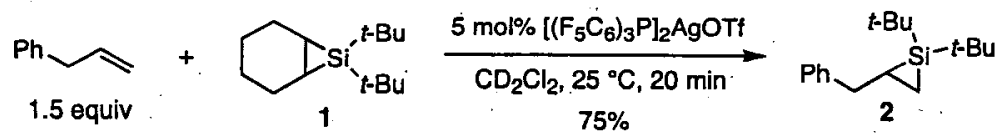

To a solution containing cyclohexene silacyclopropane $1(0.0168 \mathrm{~g}, 0.0748 \mathrm{mmol})$ and allylbenzene $(0.013 \mathrm{~mL}$, $0.100 \mathrm{mmol}$ ) in $0.300 \mathrm{~mL}$ of a $0.06237 \mathrm{M}$ solution of $\mathrm{PhSiMe}_{3}$ in $\mathrm{CD}_{2} \mathrm{Cl}_{2}$ was added, dropwise, a suspension 
containing $0.0134 \mathrm{~g}\left\{\left[\left(\mathrm{~F}_{5} \mathrm{C}_{6}\right)_{3} \mathrm{P}\right]_{2} \mathrm{AgOTf}\right\}_{\mathrm{n}} \cdot \mathrm{PhCH}_{3}(0.00475 \mathrm{mmol})$ in $0.300 \mathrm{~mL}$ of a $0.06237 \mathrm{M}$ solution of $\mathrm{PhSiMe}_{3}$ in $\mathrm{CD}_{2} \mathrm{Cl}_{2}$. Immediately, the color of the reaction mixture turned black and a fine black precipitate became visible. Analysis of the reaction progress after $20 \mathrm{~min}$ using ${ }^{1} \mathrm{H}$ NMR spectroscopy revealed complete consumption of 1 and formation of product silacyclopropane 2 (75\% relative to internal standard). Refer to s-44 for the ${ }^{1} \mathrm{H}$ NMR spectral data describing the experiment.

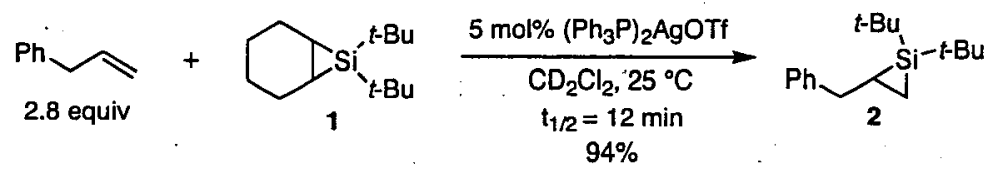

To a cold $\left(-78{ }^{\circ} \mathrm{C}\right)$ solution containing cyclohexene silacyclopropane $1(0.0113 \mathrm{~g}, 0.0503 \mathrm{mmol})$ and allylbenzene $(0.025 \mathrm{~mL}, 0.189 \mathrm{mmol})$ in $0.500 \mathrm{~mL}$ of a $0.0290 \mathrm{M}$ solution of $\mathrm{PhSiMe}_{3}$ in $\mathrm{CD}_{2} \mathrm{Cl}_{2}$ was added, dropwise, a solution containing $0.0020 \mathrm{~g}\left(\mathrm{Ph}_{3} \mathrm{P}\right)_{2} \mathrm{AgOTf}(0.0026 \mathrm{mmol})$ in $0.250 \mathrm{~mL}$ of a $0.0290 \mathrm{M}$ solution of $\mathrm{PhSiMe}_{3}$ in $\mathrm{CD}_{2} \mathrm{Cl}_{2}$. After agitation the NMR tube containing the reaction mixture was placed in a cool $\left(-40^{\circ} \mathrm{C}\right)$ NMR spectrometer. The reaction mixture was warmed to $25^{\circ} \mathrm{C}$ in the NMR spectrometer (no reaction was observed below $0^{\circ} \mathrm{C}$ ). The reaction progress was monitored periodically using ${ }^{1} \mathrm{H}$ NMR spectroscopy over five half-lives. The reaction was complete (94\%) after $79 \mathrm{~min}$ (Figure s3).

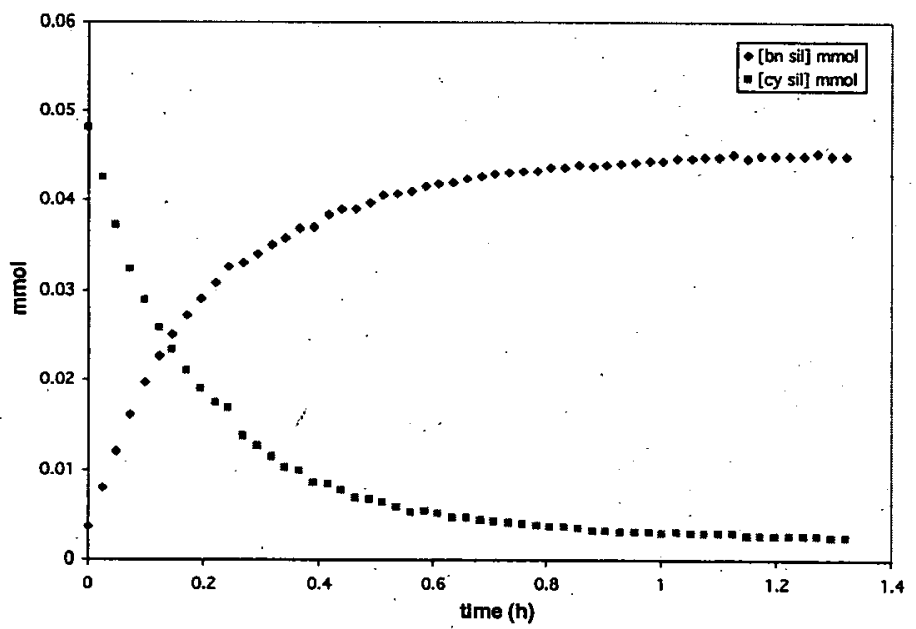

Figure s3. Reaction Progress at $25^{\circ} \mathrm{C}$

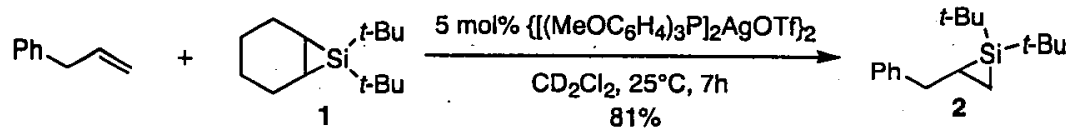

To a solution containing cyclohexene silacyclopropane $1(0.0168 \mathrm{~g}, 0.0748 \mathrm{mmol})$ and allylbenzene $(0.013 \mathrm{~mL}$, $0.10 \mathrm{mmol}$ ) in $0.300 \mathrm{~mL}$ of a $0.06237 \mathrm{M}$ solution of $\mathrm{PhSiMe}_{3}$ in $\mathrm{CD}_{2} \mathrm{Cl}_{2}$ was added, dropwise, a solution containing $0.0104 \mathrm{~g}\left\{\left[\left(\mathrm{MeOC}_{4} \mathrm{H}_{4}\right)_{3} \mathrm{P}\right]_{2} \mathrm{AgOTf}\right\}_{2}(0.00541 \mathrm{mmol})$ in $0.300 \mathrm{~mL}$ of a $0.06237 \mathrm{M}$ solution of $\mathrm{PhSiMe}_{3}$ in $\mathrm{CD}_{2} \mathrm{Cl}_{2}$. The color of the reaction mixture remained clear. Analysis of the reaction progress after $30 \mathrm{~min}$ using ${ }^{1} \mathrm{H}$ NMR spectroscopy revealed approximately $25 \%$ consumption of 1 . Analysis of the reaction progress after $7 \mathrm{~h}$ revealed complete consumption of 1 and formation of product silacyclopropane 2 (81\% relative to $\mathrm{PhSiMe}_{3}$ internal standard). Refer to $\mathrm{s}-45$ and s-46 for the ${ }^{1} \mathrm{H}$ NMR spectral data describing the experiment. 
(C) 2004 American Chemical Society, J. Am. Chem. Soc., Driver ja0306563 Supporting Info Page 7

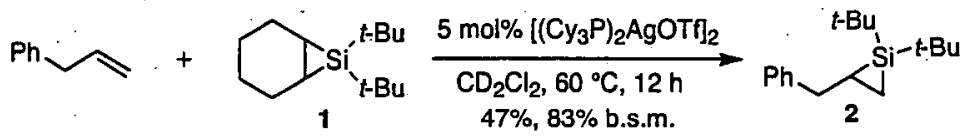

To a solution containing cyclohexene silacyclopropane $1(0.0160 \mathrm{~g}, 0.0713 \mathrm{mmol})$ and allylbenzene $(0.013 \mathrm{~mL}$, $0.10 \mathrm{mmol}$ ) in $0.300 \mathrm{~mL}$ of a $0.109 \mathrm{M}$ solution of TMS in $\mathrm{CD}_{2} \mathrm{Cl}_{2}$. (contained in a valved $\mathrm{NMR}$ tube) was added, dropwise, a solution containing $0.0115 \mathrm{~g}\left[\left(\mathrm{Cy}_{3} \mathrm{P}\right)_{2} \mathrm{AgOTf}\right]_{2}(0.00703 \mathrm{mmol})$ in $0.300 \mathrm{~mL}$ of a $0.109 \mathrm{M}$ solution of TMS in $\mathrm{CD}_{2} \mathrm{Cl}_{2}$. The color of the reaction mixture remained clear. Analysis of the reaction progress after 40 min at $25^{\circ} \mathrm{C}$ using ${ }^{1} \mathrm{H}$ NMR spectroscopy revealed no reaction. After an additional $7 \mathrm{~h}$, no reaction progress was observed. The reaction mixture was heated to $60^{\circ} \mathrm{C}$. After $14 \mathrm{~h}$, analysis of the reaction progress revealed approximately $43 \%$ consumption of 1 and formation of product silacyclopropane 2 (47\% conversion). After an additional $5 \mathrm{~d}$ at $60^{\circ} \mathrm{C}$, no apparent decrease in the amount of product silacyclopropane 2 was observed. Refer to s-47 and s-48 for the ${ }^{1} \mathrm{H}$ NMR spectral data describing the experiment.

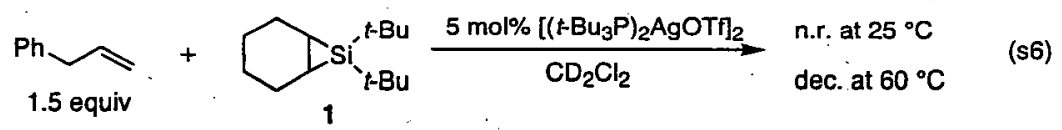

To a solution containing cyclohexene silacyclopropane $1(0.0171 \mathrm{~g}, 0.07618 \mathrm{mmol})$ and allylbenzene $(0.013$ $\mathrm{mL}, 0.10 \mathrm{mmol}$ ) in $0.300 \mathrm{~mL}$ of a $0.109 \mathrm{M}$ solution of TMS in $\mathrm{CD}_{2} \mathrm{Cl}_{2}$. (contained in a valved NMR tube) was added, dropwise, a solution containing $0.0097 \mathrm{~g}\left[\left(t-\mathrm{Bu}_{3} \mathrm{P}\right)_{2} \mathrm{AgOTf}\right]_{2}(0.0073 \mathrm{mmol})$ in $0.300 \mathrm{~mL}$ of a $0.109 \mathrm{M}$ solution of TMS in $\mathrm{CD}_{2} \mathrm{Cl}_{2}$. The color of the reaction mixture remained clear. Analysis of the reaction progress after $40 \mathrm{~min}$ using ${ }^{1} \mathrm{H}$ NMR spectroscopy revealed no reaction. After an additional $7 \mathrm{~h}$, no reaction progress was observed. The reaction mixture was heated to $60^{\circ} \mathrm{C}$. After $14 \mathrm{~h}$, analysis of the reaction progress revealed approximately $76 \%$ consumption of 1 and formation of product silacyclopropane 2 (33\% conversion). Considerable amounts of decomposition products were observed between $\delta 1.0$ and $1.6 \mathrm{ppm}$. Refer to s-49 and $\mathrm{s}-50$ for the ${ }^{1} \mathrm{H}$ NMR spectral data describing the experiment.

\section{Reactivity of various silacyclopropanes}

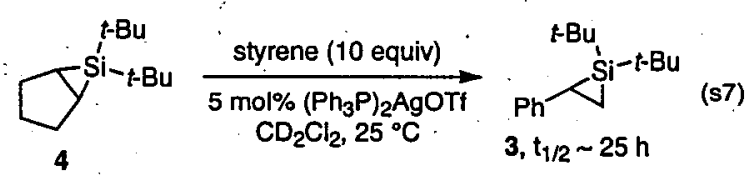

To a solution of cyclopentene silacyclopropane $4\left(0.0650 \mathrm{~mL}\right.$ of a $0.4455 \mathrm{M}$ solution in $\left.\mathrm{CD}_{2} \mathrm{Cl}_{2}, 0.02896 \mathrm{mmol}\right)$ in $0.300 \mathrm{~mL}$ of a $0.0174 \mathrm{M}$ solution of $\mathrm{PhSiMe}_{3}$ in $\mathrm{CD}_{2} \mathrm{Cl}_{2}$ (contained in a valved NMR tube) was added a solution containing styrene $(0.0100 \mathrm{~mL}, 0.0869 \mathrm{mmol})$ and $\left(\mathrm{Ph}_{3} \mathrm{P}\right)_{2} \mathrm{AgOTf}(0.0500 \mathrm{~mL}$ of a $0.02896 \mathrm{M}$ solution in $\mathrm{CD}_{2} \mathrm{Cl}_{2}, 0.00145 \mathrm{mmol}$ ) in $0.280 \mathrm{~mL}$ of a $0.0174 \mathrm{M}$ solution of $\mathrm{PhSiMe}_{3}$ in $\mathrm{CD}_{2} \mathrm{Cl}_{2}$. The NMR tube was sealed and the reaction mixture was shaken five times. After $16 \mathrm{~h}$, the reaction progress was monitored using ${ }^{1} \mathrm{H}$ NMR spectroscopy to reveal the formation of 3 in $34 \%$ yield (relative to the internal standard). The half life of the reaction was estimated to be $25 \mathrm{~h}$. Refer to s-51 for the ${ }^{1} \mathrm{H}$ NMR spectral data describing the experiment.

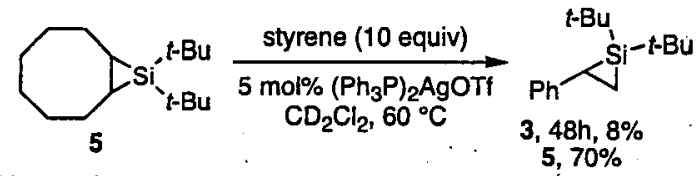

To a solution of cyclooctene silacyclopropane $5\left(0.0730 \mathrm{~mL}\right.$ of a $0.3960 \mathrm{M}$ solution in $\left.\mathrm{CD}_{2} \mathrm{Cl}_{2}, 0.02896 \mathrm{mmol}\right)$ in $0.300 \mathrm{~mL}$ of a $0.0174 \mathrm{M}$ solution of $\mathrm{PhSiMe}_{3}$ in $\mathrm{CD}_{2} \mathrm{Cl}_{2}$ (contained in a valved NMR tube) was added a solution containing styrene $(0.0100 \mathrm{~mL}, 0.0869 \mathrm{mmol})$ and $\left(\mathrm{Ph}_{3} \mathrm{P}\right)_{2}$ AgOTf $(0.0500 \mathrm{~mL}$ of a $0.02896 \mathrm{M}$ solution in $\mathrm{CD}_{2} \mathrm{Cl}_{2}, 0.00145 \mathrm{mmol}$ ) in $0.280 \mathrm{~mL}$ of a $0.0174 \mathrm{M}$ solution of $\mathrm{PhSiMe}_{3}$ in $\mathrm{CD}_{2} \mathrm{Cl}_{2}$. The NMR tube was 
sealed, and the reaction mixture was shaken five times. After $16 \mathrm{~h}$, the reaction progress was measured using ${ }^{1} \mathrm{H}$ NMR spectroscopy to reveal no formation of 3 . The reaction mixture was warmed to $50{ }^{\circ} \mathrm{C}$ for $16 \mathrm{~h}$. Analysis of the reaction progress revealed the formation of 3 in $5 \%$ yield (5 remained in $80 \%$ yield). The reaction mixture was warmed to $60^{\circ} \mathrm{C}$ for an additional $24 \mathrm{~h}$. Analysis of the reaction progress revealed formation of 3 in $8 \%$ yield and consumption of 5 ( 5 remained in $70 \%$ yield). Refer to s-52 for the ${ }^{1} \mathrm{H}$ NMR spectral data describing the experiment.

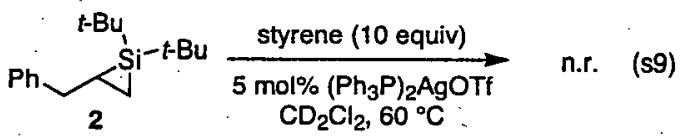

To a solution of $\left(\mathrm{Ph}_{3} \mathrm{P}\right)_{2} \mathrm{AgOTf}\left(0.100 \mathrm{~mL}\right.$ of a $0.02896 \mathrm{M}$ solution in $\left.\mathrm{CD}_{2} \mathrm{Cl}_{2}, 0.00288 \mathrm{mmol}\right)$ in $0.300 \mathrm{~mL}$ of a $0.0174 \mathrm{M}$ solution of $\mathrm{PhSiMe}_{3}$ in $\mathrm{CD}_{2} \mathrm{Cl}_{2}$ (contained in a valved $\mathrm{NMR}$ tube) was added a solution containing $0.0146 \mathrm{~g}$ benzyl silacyclopropane 2 and styrene $(0.0200 \mathrm{~mL}, 0.173 \mathrm{mmol})$ in $0.280 \mathrm{~mL}$ of a $0.0174 \mathrm{M}$ solution of $\mathrm{PhSiMe}$ in $\mathrm{CD}_{2} \mathrm{Cl}_{2}$. The NMR tube was sealed, and the reaction mixture was shaken five times. After $16 \mathrm{~h}$, the reaction progress was measured using ${ }^{1} \mathrm{H}$ NMR spectroscopy to reveal no reaction. The reaction mixture was heated to $50^{\circ} \mathrm{C}$ for $16 \mathrm{~h}$. Analysis of the reaction progress revealed no reaction. The reaction mixture was warmed to $60^{\circ} \mathrm{C}$ for an additional $24 \mathrm{~h}$. Analysis of the reaction progress revealed no formation of 3 and silacyclopropane 2 remained in $93 \%$ (relative to an internal standard). Refer to s-53 for the ${ }^{1} \mathrm{H}$ NMR spectral data describing the experiment.

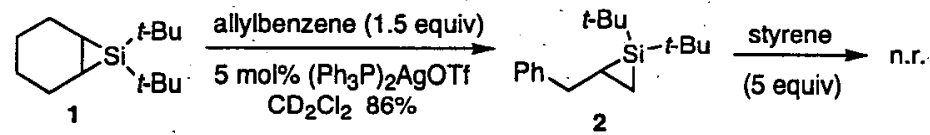

To a solution of cyclohexene silacyclopropane $1\left(0.0500 \mathrm{~mL}\right.$ of a $0.4455 \mathrm{M}$ solution in $\left.\mathrm{CD}_{2} \mathrm{Cl}_{2}, 0.02896 \mathrm{mmol}\right)$ in $0.300 \mathrm{~mL}$ of a $0.0174 \mathrm{M}$ solution of $\mathrm{PhSiMe}_{3}$ in $\mathrm{CD}_{2} \mathrm{Cl}_{2}$ (contained in a NMR tube) was added a solution containing allylbenzene $(0.0120 \mathrm{~mL}, 0.0869 \mathrm{mmol})$ and $\left(\mathrm{Ph}_{3} \mathrm{P}\right)_{2} \mathrm{AgOTf}(0.0500 \mathrm{~mL}$ of a $0.02896 \mathrm{M}$ solution in $\mathrm{CD}_{2} \mathrm{Cl}_{2}, 0.00145 \mathrm{mmol}$ ) in $0.280 \mathrm{~mL}$ of a $0.0174 \mathrm{M}$ solution of $\mathrm{PhSiMe}_{3}$. in $\mathrm{CD}_{2} \mathrm{Cl}_{2}$. The reaction mixture was shaken five times. After $4 \mathrm{~h}$, the reaction progress was measured using ${ }^{1} \mathrm{H}$ NMR spectroscopy to reveal formation of 2 in $86 \%$ yield $(0.0249 \mathrm{mmol})$. To this mixture was added $0.0330 \mathrm{~mL}$ of styrene, and the reaction mixture was shaken five times. After an additional $24 \mathrm{~h}$, analysis of the reaction progress revealed no formation of styrene silacyclopropane 3 ( 2 remained in $0.0233 \mathrm{mmol}(94 \%)$, relative to the internal standard). Refer to s54 and s-55 for the ${ }^{1} \mathrm{H}$ NMR spectral data describing the experiment.

\section{Determination of kinetic order}
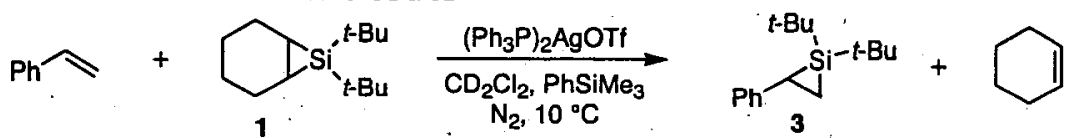

\section{A. Determination of order in cyclohexene silacyclopropane 1 concentration}

The general procedure is illustrated for the reaction of cyclohexene silacyclopropane 1 with excess styrene in the presence of $5 \mathrm{~mol} \%\left(\mathrm{Ph}_{3} \mathrm{P}\right)_{2} \mathrm{AgOTf}$. To a cool $\left(-78^{\circ} \mathrm{C}\right)$ solution of cyclohexene silacyclopropane $1(0.0320$ $\mathrm{mL}$ of a $0.4455 \mathrm{M}$ solution in $\mathrm{CD}_{2} \mathrm{Cl}_{2}, 0.0143 \mathrm{mmol}$ ) in $0.300 \mathrm{~mL}$ of a $0.0174 \mathrm{M}$ solution of $\mathrm{PhSiMe}_{3}$ in $\mathrm{CD}_{2} \mathrm{Cl}_{2}$ (contained in a thin wall NMR tube) was added, dropwise, a solution containing styrene $(0.0500 \mathrm{~mL}, 0.436$ $\mathrm{mmol})$ and $\left(\mathrm{Ph}_{3} \mathrm{P}\right)_{2}$ AgOTf $\left(0.0500 \mathrm{~mL}\right.$ of a $0.02896 \mathrm{M}$ solution in $\left.\mathrm{CD}_{2} \mathrm{Cl}_{2}, 0.00145 \mathrm{mmol}\right)$ in $0.270 \mathrm{~mL}$ of a $0.0174 \mathrm{M}$ solution of $\mathrm{PhSiMe}_{3}$ in $\mathrm{CD}_{2} \mathrm{Cl}_{2}$. After thermal equilibration to $-78{ }^{\circ} \mathrm{C}$, the resulting solution was shaken five times. The reaction mixture was re-cooled to $-78^{\circ} \mathrm{C}$, and then it was placed in a cool $\left(-20^{\circ} \mathrm{C}\right)$ 
NMR spectrometer. An initial ${ }^{1} \mathrm{H}$ NMR spectrum was obtained, and the temperature of the spectrometer was regulated to $10^{\circ} \mathrm{C}$. Periodically the reaction progress was measured relative to the internal standard of $\mathrm{PhSiMe}_{3}$ using ${ }^{1} \mathrm{H}$ NMR spectroscopy. Each experiment was performed in triplicate. The concentrations of the reactants and products were obtained by comparison of the area of the standard $\left(\mathrm{PhSiMe}_{3}, \delta 0.23 \mathrm{ppm}\right.$; area $=1.0000$ ) and the area of the $t$-Bu peaks of the silacyclopropanes 1 and $3(1, \delta 1.20 \mathrm{ppm} ; 3, \delta 0.83 \mathrm{ppm})$. The data was fit to the best straight line using a least-squares program to obtain $k_{\text {init }}$ values. For the remaining experiments, the amount of cyclohexene silacyclopropane 1 was increased in small increments $(0.0650,0.0980$, and $0.1300 \mathrm{~mL})$ while the styrene and catalyst concentrations remained constant. A sample plot (Figure s4) from an experimental run is included below. Figure s 5 and Table s 2 summarize the results.

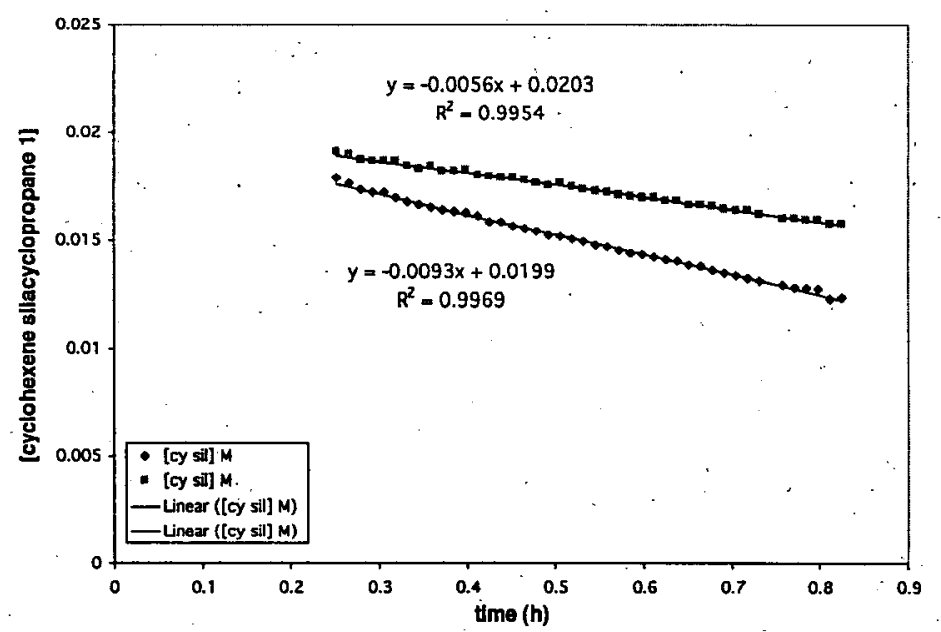

Figure s4. Sample experiment for $0.0203 \mathrm{M}$ cyclohexene silacyclopropane 1

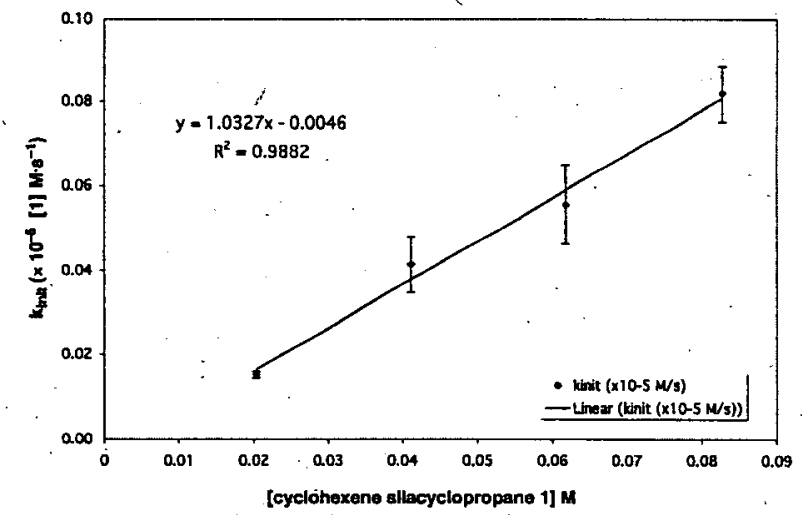

Figure s5. Kinetic order in cyclohexene silacyclopropane 1 concentration

Table s2. Summary of data used in the determination of kinetic order in cyclohexene silacyclopropane 1

\begin{tabular}{|c|c|c|c|c|c|c|}
\hline \multirow{2}{*}{ Entry } & \multirow{2}{*}{$1(\mathrm{M})$} & \multicolumn{3}{|c|}{$k_{\text {int }}\left(\times 10^{-5}[1] \mathrm{M} / \mathrm{s}\right)\left(\mathrm{r}^{2}-\right.$ value $)$} & \multirow{2}{*}{$\begin{array}{c}\text { av } k_{\text {init }} \\
\left(\times 10^{-5}[1] \mathrm{M} / \mathrm{s}\right)\end{array}$} & \multirow{2}{*}{$\begin{array}{l}\text { Error (std } \\
\text { deviation) }\end{array}$} \\
\hline & & Run 1 & Run 2 & Run 3 & & \\
\hline 1 & 0.02031 & $0.0156(0.9900)$ & $0.0156(0.9954)$ & $0.0142(0.9953)$ & 0.0151 & 0.0008 \\
\hline 2 & 0.04108 & $0.0489(0.9915)$ & $0.0358(0.9915)$ & $0.0394(0.9916)$ & 0.0414 & 0.0067 \\
\hline 3 & 0.06170 & $0.0656(0.9915)$ & $0.0472(0.9924)$ & $0.0542(0.9948)$ & 0.0556 & 0.009 \\
\hline 4 & 0.08270 & $0.0886(0.9900)$ & $0.0814(0.9953)$ & $0.0757(0.9942)$ & 0.0819 & 0.0065 \\
\hline
\end{tabular}




\section{B. Determination of order in styrene concentration}

The general procedure is illustrated for the reaction of cyclohexene silacyclopropane 1 with excess styrene in the presence of $5 \mathrm{~mol} \%\left(\mathrm{Ph}_{3} \mathrm{P}\right)_{2} \mathrm{AgOTf}$. To a cool $\left(-78^{\circ} \mathrm{C}\right)$ solution of cyclohexene silacyclopropane $1(0.0650$ $\mathrm{mL}$ of a $0.4455 \mathrm{M}$ solution in $\mathrm{CD}_{2} \mathrm{Cl}_{2}, 0.0299 \mathrm{mmol}$ ) in $0.300 \mathrm{~mL}$ of a $0.0174 \mathrm{M}$ solution of $\mathrm{PhSiMe}_{3}$ in $\mathrm{CD}_{2} \mathrm{Cl}_{2}$ (contained in a thin wall NMR tube) was added, dropwise, a solution containing styrene $(0.0660 \mathrm{~mL}, 0.579$ $\mathrm{mmol})$ and $\left(\mathrm{Ph}_{3} \mathrm{P}\right)_{2} \mathrm{AgOTf}\left(0.0500 \mathrm{~mL}\right.$ of a $0.02896 \mathrm{M}$ solution in $\left.\mathrm{CD}_{2} \mathrm{Cl}_{2}, 0.00145 \mathrm{mmol}\right)$ in $0.220 \mathrm{~mL}$ of a $0.0174 \mathrm{M}$ solution of $\mathrm{PhSiMe}_{3}$ in $\mathrm{CD}_{2} \mathrm{Cl}_{2}$. After thermal equilibration to $-78^{\circ} \mathrm{C}$, the resulting solution was shaken five times. The reaction mixture was re-cooled to $-78{ }^{\circ} \mathrm{C}$, and then it was placed in a cool $\left(-20^{\circ} \mathrm{C}\right)$ NMR spectrometer. An initial ${ }^{1} \mathrm{H}$ NMR spectrum was obtained, and the temperature of the spectrometer was regulated to $10^{\circ} \mathrm{C}$. Periodically the reaction progress was measured relative to the internal standard of $\mathrm{PhSiMe}_{3}$ using ${ }^{1} \mathrm{H}$ NMR spectroscopy. Each experiment was performed in triplicate. The concentrations of the reactants and products were obtained by comparison of the area of the standard $\left(\mathrm{PhSiMe}_{3}, \delta 0.23 \mathrm{ppm}\right.$; area $\left.=1.0000\right)$ and the area of the $t$-Bu peaks of the silacyclopropanes 1 and $3(1, \delta 1.20 \mathrm{ppm} ; 3, \delta 0.83 \mathrm{ppm})$. The data was fit to the best straight line using a least-squares program to obtain $k_{\text {init }}$ values. A sample plot (Figure s6) from an experimental run is included below. Figure s7 and Table s3 summarize the results.

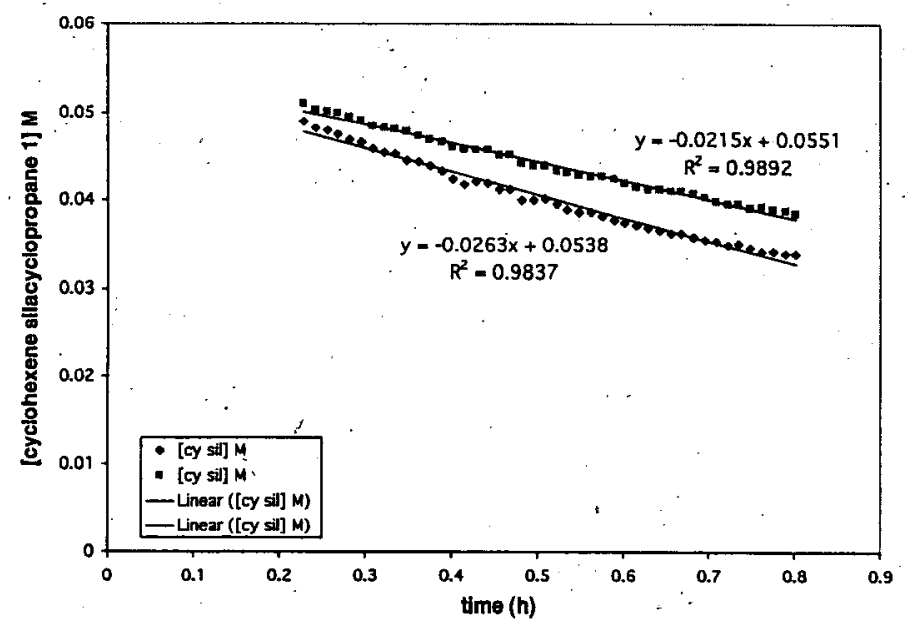

Figure s6. Sample experiment for $0.660 \mathrm{M}$ styrene

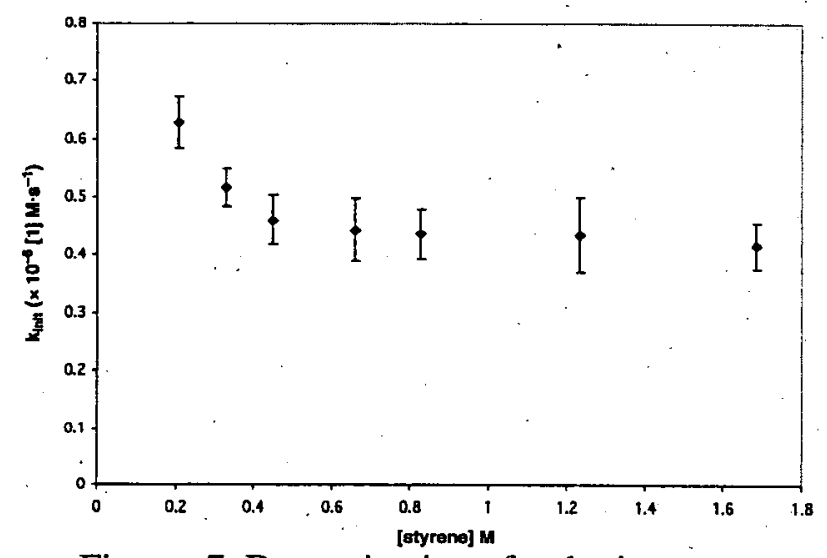

Figure s7. Determination of order in styrene. 
(C) 2004 American Chemical Society, J. Am. Chem. Soc., Driver ja0306563 Supporting Info Page 11

Supporting Information: Tom G. Driver and K. A. Woerpel

Table s3. Summary of the data for the determination of kinetic order in styrene

\begin{tabular}{|c|c|c|c|c|c|c|}
\hline \multirow{2}{*}{ Entry } & \multirow{2}{*}{ styrene $(\mathrm{M})$} & \multicolumn{3}{|c|}{$k_{\text {init }}\left(\times 10^{-6}[\mathbf{1}] \mathrm{M} / \mathrm{s}\right)\left(\mathrm{r}^{2}\right.$-value $)$} & \multirow{2}{*}{$\begin{array}{c}\text { av } k_{\text {init }} \\
\left(\times 10^{-6}[\mathbf{1}] \mathrm{M} / \mathrm{s}\right)\end{array}$} & \multirow{2}{*}{$\begin{array}{l}\text { Error (std } \\
\text { deviation) }\end{array}$} \\
\hline & & Run 1 & Run 2 & Run 3 & & \\
\hline 1 & 0.206 & $0.6694(0.9893)$ & $0.5806(0.9831)$ & $0.6361(0.9876)$ & 0.6287 & 0.045 \\
\hline 2 & 0.450 & $0.4889(0.9754)$ & $0.5500(0.9692)$ & $0.5083(0.9840)$ & 0.5157 & 0.031 \\
\hline 3 & 0.546 & $0.4111(0.9964)$ & $0.4861(0.9956)$ & $0.4833(0.9970)$ & 0.4601 & 0.043 \\
\hline $4 a$ & 0.660 & $0.4889(0.9915)$ & $0.3583(0.9915)$ & $0.3944(0.9916)$ & \multirow[b]{2}{*}{0.4426} & \multirow[b]{2}{*}{0.054} \\
\hline $4 b$ & 0.660 & $0.4694(0.9682)$ & $0.4556(0.9878)$ & $0.4889(0.9910)$ & & \\
\hline 5 & 0.826 & $0.4111(0.9982)$ & $0.4861(0.9732)$ & $0.4083(0.9929)$ & 0.4352 & 0.044 \\
\hline 6 & 1.23 & $0.3778(0.9831)$ & $0.4194(0.9837)$ & $0.5050(0.9620)$ & 0.4342 & 0.065 \\
\hline 7 & 1.68 & $0.4139(0.9824)$ & $0.4111(0.9871)$ & $0.4222(0.9151)$ & 0.4157 & 0.041 \\
\hline
\end{tabular}

\section{Determination of order in cyclohexene concentration}

The general procedure is illustrated for the reaction of cyclohexene silacyclopropane 1 with excess styrene in the presence of $5 \mathrm{~mol} \%\left(\mathrm{Ph}_{3} \mathrm{P}\right)_{2} \mathrm{AgOTf}$. To a cool $\left(-78^{\circ} \mathrm{C}\right)$ solution of cyclohexene silacyclopropane $1(0.0650$ $\mathrm{mL}$ of a $0.4455 \mathrm{M}$ solution in $\mathrm{CD}_{2} \mathrm{Cl}_{2}, 0.0290 \mathrm{mmol}$ ) in $0.300 \mathrm{~mL}$ of a $0.0174 \mathrm{M}$ solution of $\mathrm{PhSiMe}_{3}$ in $\mathrm{CD}_{2} \mathrm{Cl}_{2}$ (contained in a thin wall NMR tube) was added, dropwise, a solution containing styrene $(0.0170 \mathrm{~mL}, 0.148$ $\mathrm{mmol})$, cyclohexene $(0.0100 \mathrm{~mL}, 0.0987 \mathrm{mmol})$ and $\left(\mathrm{Ph}_{3} \mathrm{P}\right)_{2} \mathrm{AgOTf}(0.0500 \mathrm{~mL}$ of a $0.02896 \mathrm{M}$ solution in $\mathrm{CD}_{2} \mathrm{Cl}_{2}, 0.00145 \mathrm{mmol}$ ) in $0.260 \mathrm{~mL}$ of a $0.0174 \mathrm{M}$ solution of $\mathrm{PhSiMe}$ in $\mathrm{CD}_{2} \mathrm{Cl}_{2}$. After thermal equilibration to $-78^{\circ} \mathrm{C}$, the resulting solution was shaken five times. The reaction mixture was re-cooled to $-78^{\circ} \mathrm{C}$, and then it was placed in a cool $\left(-20^{\circ} \mathrm{C}\right) \mathrm{NMR}$ spectrometer. An initial ${ }^{1} \mathrm{H}$ NMR spectrum was obtained; and the temperature of the spectrometer was regulated to $10^{\circ} \mathrm{C}$. Periodically the reaction progress was measured relative to the internal standard of $\mathrm{PhSiMe}_{3}$ using ${ }^{1} \mathrm{H}$ NMR spectroscopy. Each experiment was performed in triplicate. The concentrations of the reactants and products were obtained by comparison of the area of the standard $\left(\mathrm{PhSiMe}_{3}, \delta 0.23 \mathrm{ppm}\right.$; area = 1.0000) and the area of the $t$-Bu peaks of the silacyclopropanes 1 and 3 $(1, \delta 1.20 \mathrm{ppm} ; 3, \delta 0.83 \mathrm{ppm})$. The data was fit to the best straight line using a least-squares program to obtain $k_{\text {init }}$ values. A sample plot (Figure s8) from an experimental run is included below. Figure s9 and Table s4 summarize the results.

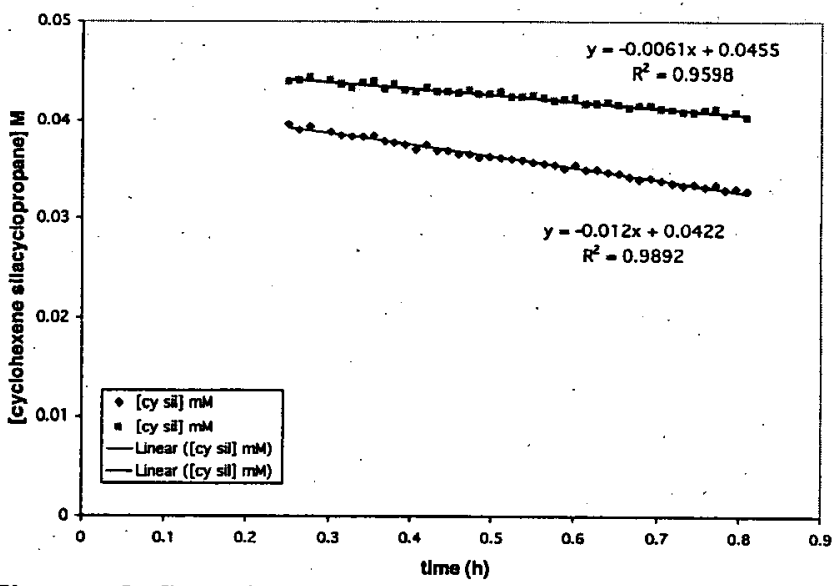

Figure s8. Sample experiment for $0.213 \mathrm{M}$ cyclohexene 


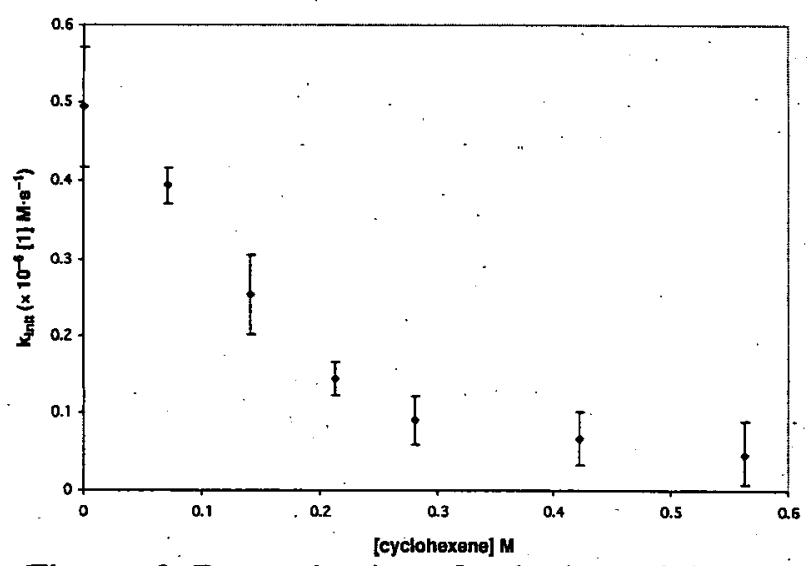

Figure s9. Determination of order in cyclohexene

Table s4. Summary of the data for the determination of kinetic order in cyclohexene

\begin{tabular}{|c|c|c|c|c|c|c|}
\hline \multirow{2}{*}{ Entry } & \multirow{2}{*}{$\begin{array}{c}\text { cyclohexene } \\
(\mathrm{M})\end{array}$} & \multicolumn{3}{|c|}{$k_{\text {int }}\left(\times 10^{-6}[1] \mathrm{M} / \mathrm{s}\right)\left(\mathrm{r}^{2}\right.$-value $)$} & \multirow{2}{*}{$\begin{array}{c}\text { av } k_{\text {init }} \\
\left(\times 10^{-6}[1] \mathrm{M} / \mathrm{s}\right)\end{array}$} & \multirow{2}{*}{$\begin{array}{l}\text { Error (std } \\
\text { deviation) }\end{array}$} \\
\hline & & Run 1 & Run 2 & Run 3 & & \\
\hline 1 & 0.000 & $0.5194(0.9709)$ & $0.4083(0.9783)$ & $0.5556(0.9767)$ & $0: 4944$ & 0.076 \\
\hline 2 & 0.07082 & $0.4083(0.9918)$ & $0.3667(0.9955)$ & $0.4056(0.9954)$ & 0.3935 & 0.023 \\
\hline 3 & 0.1406 & $0.2944(0.9886)$ & $0.1944(0.9871)$ & $0.2722(0.9643)$ & 0.2537 & 0.052 \\
\hline 4 & 0.213 & $0.1361(0.9689)$ & $0.1278(0.9651)$ & $0.1694(0.9598)$ & 0.1444 & 0.022 \\
\hline 5 & 0.2812 & $0.1266(0.9949)$ & $0.0861(0.9763)$ & $0.0639(0.6084)$ & 0.09074 & 0.029 \\
\hline 6 & 0.4219 & $0.0806(0.3275)$ & $0.0306(0.2003)$ & $.0 .0944(0.8109)$ & 0.06852 & 0.034 \\
\hline 7 & 0.5628 & $0.0417(0.3697)$ & $0.0111(0.8792)$ & $0.0917(0.8914)$ & 0.04815 & 0.041 \\
\hline
\end{tabular}

\section{Determination of order in $\left(\mathrm{Ph}_{3} \mathrm{P}\right)_{2} \mathrm{AgOTf}$ concentration}

The general procedure is illustrated for the reaction of cyclohexene silacyclopropane 1 with excess styrene in the presence of $1 \mathrm{~mol} \%\left(\mathrm{Ph}_{3} \mathrm{P}\right)_{2} \mathrm{AgOTf}$. To a cool $\left(-78^{\circ} \mathrm{C}\right)$ solution of cyclohexene silacyclopropane $1(0.0650$ $\mathrm{mL}$ of a $0.4455 \mathrm{M}$ solution in $\mathrm{CD}_{2} \mathrm{Cl}_{2}, 0.0290 \mathrm{mmol}$ ) in $0.300 \mathrm{~mL}$ of a $0.0174 \mathrm{M}$ solution of $\mathrm{PhSiMe}_{3}$ in $\mathrm{CD}_{2} \mathrm{Cl}_{2}$ (contained in a thin wall NMR tube) was added, dropwise, a solution containing styrene $(0.0170 \mathrm{~mL}, 0.145$ $\mathrm{mmol})$ and $\left(\mathrm{Ph}_{3} \mathrm{P}\right)_{2} \mathrm{AgOTf}\left(0.0100 \mathrm{~mL}\right.$ of a $0.02896 \mathrm{M}$ solution in $\left.\mathrm{CD}_{2} \mathrm{Cl}_{2}, 0.00145 \mathrm{mmol}\right)$ in $0.310 \mathrm{~mL}$ of a $0.0174 \mathrm{M}$ solution of $\mathrm{PhSiMe}_{3}$ in $\mathrm{CD}_{2} \mathrm{Cl}_{2}$. After thermal equilibration to $-78^{\circ} \mathrm{C}$, the resulting solution was shaken five times. The reaction mixture was re-cooled to $-78{ }^{\circ} \mathrm{C}$, and then it was placed in a cool $\left(-20{ }^{\circ} \mathrm{C}\right)$ NMR spectrometer. An initial ${ }^{1} \mathrm{H}$ NMR spectrum was obtained, and the temperature of the spectrometer was regulated to $10^{\circ} \mathrm{C}$. Periodically the reaction progress was measured relative to the internal standard of $\mathrm{PhSiMe}_{3}$ using ${ }^{1} \mathrm{H}$ NMR spectroscopy. Each experiment was performed in triplicate. The concentrations of the reactants and products were obtained by comparison of the area of the standard $\left(\mathrm{PhSiMe}_{3}, \delta 0.23 \mathrm{ppm}\right.$; area $\left.=1.0000\right)$ and the area of the $t$-Bu peaks of the silacyclopropanes 1 and $3(1, \delta 1.20 \mathrm{ppm} ; 3, \delta 0.83 \mathrm{ppm})$. The data was fit to the best straight line using a least-squares program to obtain $k_{\text {init }}$ values. For the remaining experiments, the amount of $\left(\mathrm{Ph}_{3} \mathrm{P}\right)_{2} \mathrm{AgOTf}(2,5,7.5,10$, and $15 \mathrm{~mol} \%)$ was increased in small increments while the styrene and silacyclopropane concentrations remained constant. A sample plot (Figure s10) from an experimental run is included below. Figure s11 and Table s5 summarize the results. 
(c) 2004 American Chemical Society, J. Am. Chem. Soc., Driver ja0306563 Supporting Info Page 13

Supporting Information: Tom G. Driver and K. A. Woerpel

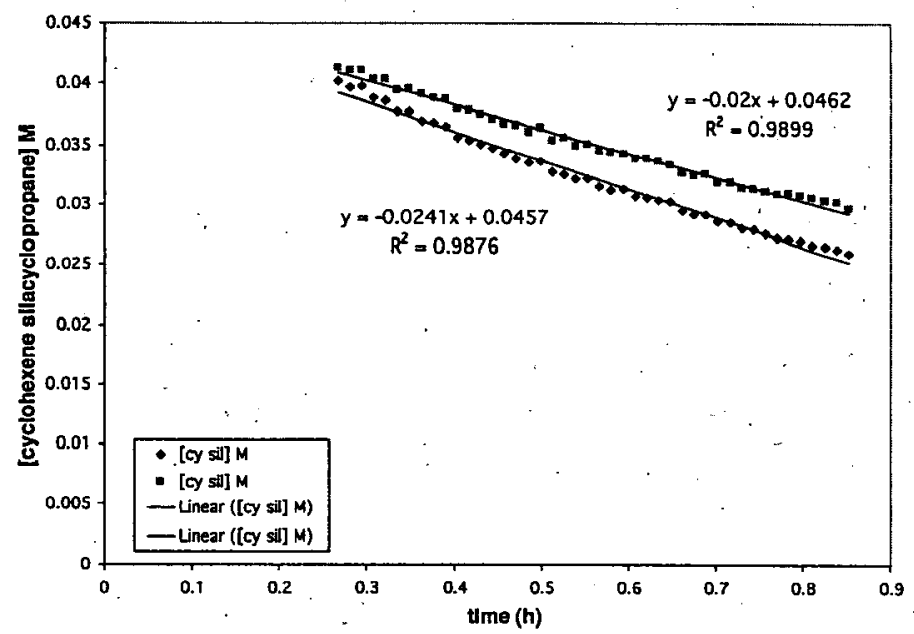

Figure s10. Sample experiment for $0.00206 \mathrm{M}\left(\mathrm{Ph}_{3} \mathrm{P}\right)_{2} \mathrm{AgOTf}$

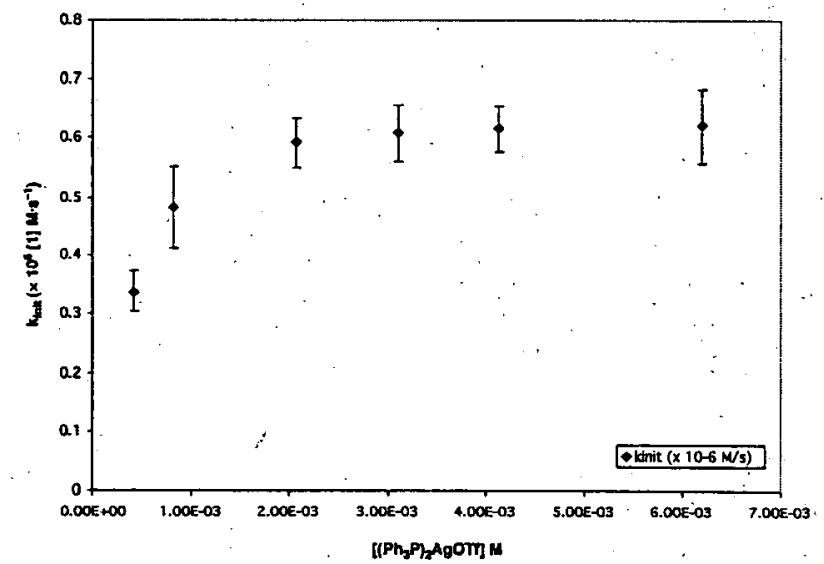

Figure s11. Determination of order in $\left(\mathrm{Ph}_{3} \mathrm{P}\right)_{2} \mathrm{AgOTf}$

Table s5. Summary of the data for the determination of kinetic order in $\left(\mathrm{Ph}_{3} \mathrm{P}\right)_{2} \mathrm{AgOTf}$

\begin{tabular}{ccccccc}
\hline Entry & $\begin{array}{c}\left(\mathrm{Ph}_{3} \mathrm{P}\right)_{2} \mathrm{AgOTf} \\
\end{array}$ & \multicolumn{3}{c}{$k_{\text {init }}\left(\times 10^{-6}[1] \mathrm{M} / \mathrm{s}\right)\left(\mathrm{r}^{2}\right.$-value $)$} & av $k_{\text {init }}$ & $\begin{array}{c}\text { Error }(\mathrm{std} \\
\text { deviation })\end{array}$ \\
\hline 1 & 0.413 & $0.3667(0.9838)$ & $0.3000(0.9949)$ & $0.3428(0.9768)$ & 0.3340 & 0.034 \\
2 & 0.825 & $0.4444(0.9947)$ & $0.5639(0.9903)$ & $0.4389(0.9267)$ & 0.4824 & .0 .071 \\
3 & 2.06 & $0.6361(0.9893)$ & $0.5806(0.9831)$ & $0.5555(0.9899)$ & 0.5907 & 0.041 \\
4 & 3.09 & $0.6000(0.9712)$ & $0.5639(0.9853)$ & $0.6583(0.9828)$ & 0.6074 & 0.048 \\
5 & 4.13 & $0.6417(0.9748)$ & $0.5694(0.9810)$ & $0.6333(0.9797)$ & 0.6148 & 0.040 \\
6 & 6.19 & $0.5472(0.9829)$ & $0.6611(0.9747)$ & $0.6556(0.9774)$ & 0.6213 & 0.064 \\
\hline
\end{tabular}


(C) 2004 American Chemical Society, J. Am. Chem. Soc., Driver ja0306563 Supporting Info Page 14

Supporting Information: Tom G. Driver and K. A. Woerpel

$s-14$

\section{Observation and analysis of the behavior of silylsilver complex 8}

A. Spectroscopic observation of a silylsilver intermediate

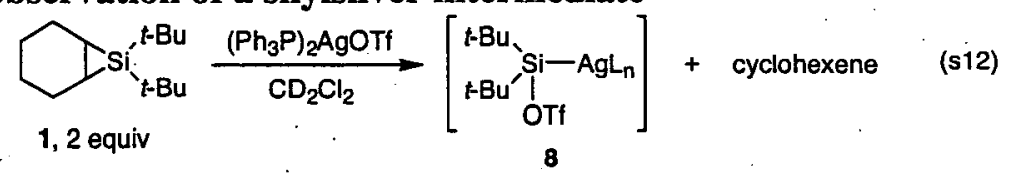

To a $25{ }^{\circ} \mathrm{C}$ solution of cyclohexene silacyclopropane $1(0.0330 \mathrm{~g}, 0.147 \mathrm{mmol})$ and $\mathrm{PhSiMe}_{3}(0.0100 \mathrm{~mL}$, $0.0581 \mathrm{mmol}$ ) in $0.300 \mathrm{~mL}$ of $\mathrm{CD}_{2} \mathrm{Cl}_{2}$ (contained in a valved NMR tube) was added a solution containing $0.0540 \mathrm{~g}\left[\left(\mathrm{Ph}_{3} \mathrm{P}\right)_{2} \mathrm{AgOTf}\right]_{2}(0.0690 \mathrm{mmol} \mathrm{Ag})$ in $0.300 \mathrm{~mL} \mathrm{CD} \mathrm{Cl}_{2}$. After three minutes, the resultant yellow solution was cooled to $-78{ }^{\circ} \mathrm{C}$. After 20 min, the reaction mixture was placed in a cool $\left(-40^{\circ} \mathrm{C}\right) \mathrm{NMR}$ spectrometer. Analysis of the ${ }^{1} \mathrm{H}$ NMR spectrum revealed the formation of $0.0640 \mathrm{mmol}$ (relative to $\mathrm{PhSiMe}_{3}$ internal standard) of cyclohexene (5.65 ppm). No further change in the ${ }^{1} \mathrm{H}$ NMR spectrum was seen after $3 \mathrm{~h}$. Refer to s-56 - s-59 for the ${ }^{1} \mathrm{H}$ NMR spectral data describing the experiment. Selected spectral data: ${ }^{1} \mathrm{H}$ NMR $\left(500 \mathrm{MHz}, \mathrm{CD}_{2} \mathrm{Cl}_{2}\right) \delta 0.98$ (br s); ${ }^{29} \mathrm{Si} \mathrm{NMR}\left(99.3 \mathrm{MHz}, \mathrm{CD}_{2} \mathrm{Cl}_{2}\right) \delta 97.1$ (d, $J=259.9 \mathrm{~Hz},{ }^{109} \mathrm{Ag}-{ }^{29} \mathrm{Si}$ coupling), 97.1 (d, $J=224.9 \mathrm{~Hz},{ }^{107} \mathrm{Ag}-{ }^{29} \mathrm{Si}$ coupling); the relative gyromagnetic ratio was found to be 1.1554 (lit. 1.15); ${ }^{6}$ ${ }^{31} \mathrm{P}$ NMR $\left(202 \mathrm{MHz}, \mathrm{CD}_{2} \mathrm{Cl}_{2}\right) \delta 6.23$ (br d, $\left.J=248 \mathrm{~Hz}\right), 4.8(\mathrm{~s}),-2-0.5$ (br s).

\section{B. Spectroscopic observation of a silylgold intermediate}

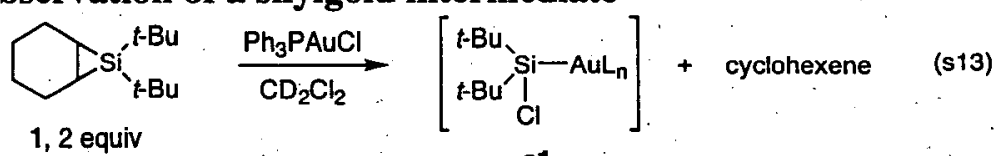

To a $25{ }^{\circ} \mathrm{C}$ solution of cyclohexene silacyclopropane $1(0.0390 \mathrm{~g}, 0.174 \mathrm{mmol})$ in $0.300 \mathrm{~mL}$ of a $0.109 \mathrm{M}$ solution of TMS in $\mathrm{CD}_{2} \mathrm{Cl}_{2}$ (contained in an NMR tube) was added a solution containing $0.0290 \mathrm{~g} \mathrm{Ph}_{3} \mathrm{PAuCl}$ $(0.0940 \mathrm{mmol})$ in $0.300 \mathrm{~mL}$ of a $0.109 \mathrm{M}$ solution of TMS in $\mathrm{CD}_{2} \mathrm{Cl}_{2}$. The resulting pink reaction mixture was placed into an NMR spectrometer and ${ }^{1} \mathrm{H}$ and ${ }^{3 !} \mathrm{P}$ NMR spectra were obtained at $25^{\circ} \mathrm{C}$. The temperature of the reaction mixture was regulated to $-20{ }^{\circ} \mathrm{C}$ and ${ }^{1} \mathrm{H},{ }^{29} \mathrm{Si}$, and ${ }^{31} \mathrm{P}$ NMR spectra were obtained. Analysis of the ${ }^{1} \mathrm{H}$ NMR spectrum revealed the formation of cyclohexene $(0.0581 \mathrm{mmol}$, relative to TMS internal standard). Cyclohexene silacyclopropane 1 was present in 0.136 mmol. Refer to s-60 - s-62 for the ${ }^{1} \mathrm{H}$ NMR spectral data describing the experiment. Selected spectral data $\left(25^{\circ} \mathrm{C}\right):{ }^{1} \mathrm{H}$ NMR $\left(500 \mathrm{MHz}, \mathrm{CD}_{2} \mathrm{Cl}_{2}\right) \delta 1.34(\mathrm{~s}), 1.25(\mathrm{~s})$, 1.15 (s); ${ }^{31} \mathrm{P}$ NMR (202 MHz, $\mathrm{CD}_{2} \mathrm{Cl}_{2}$ ) $\delta 56.9$ (s), 55 - 58 (br s), 48.5 (br s), 46.3 (br s); $\left(-20^{\circ} \mathrm{C}\right){ }^{1} \mathrm{H}$ NMR (500 $\left.\mathrm{MHz}, \mathrm{CD}_{2} \mathrm{Cl}_{2}\right) \delta 1.15$ (br s); ${ }^{29} \mathrm{Si} \mathrm{NMR}\left(99.3 \mathrm{MHz}, \mathrm{CD}_{2} \mathrm{Cl}_{2}\right) \delta 80-82$ (br m); ${ }^{31} \mathrm{P} \mathrm{NMR}\left(202 \mathrm{MHz}, \mathrm{CD}_{2} \mathrm{Cl}_{2}\right) \delta$ 56.3 (s), 53 - 60 (br s), 48.2 (br s), 45.6 (br s).

\section{Thermal stability of silylsilver complex 8}

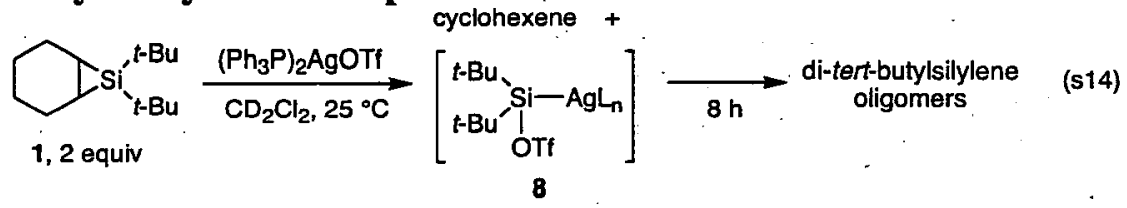

To a $25^{\circ} \mathrm{C}$ solution of cyclohexene silacyclopropane $1(0.0336 \mathrm{~g}, 0.150 \mathrm{mmol})$ in $0.200 \mathrm{~mL}$ of a $0.291 \mathrm{M}$ solution of $\mathrm{PhSiMe}_{3}$ in $\mathrm{CD}_{2} \mathrm{Cl}_{2}$ (contained in an $\mathrm{NMR}$ tube) was added a solution containing $0.0470 \mathrm{~g}$ $\left[\left(\mathrm{Ph}_{3} \mathrm{P}\right)_{2} \mathrm{AgOTf}\right]_{2}(0.0601 \mathrm{mmol} \mathrm{Ag})$ in $0.350 \mathrm{~mL}$ of $\mathrm{CD}_{2} \mathrm{Cl}_{2}$. After $3 \mathrm{~min}$, the reaction mixture was analyzed using NMR spectroscopy. Analysis of the ${ }^{1} \mathrm{H}$ NMR spectrum revealed the formation of cyclohexene $(0.0661$ mmol, relative to $\mathrm{PhSiMe}_{3}$ internal standard). Cyclohexene silacyclopropane 1 was present in $0.0493 \mathrm{mmol}$. The formation of 8 was verified by analysis of ${ }^{29} \mathrm{Si}$ and ${ }^{31} \mathrm{P}$ NMR spectra. After $8 \mathrm{~h}$, the dark reaction mixture 
was reanalyzed using NMR spectroscopy. Analysis revealed: (1) formation of more cyclohexene $(0.150 \mathrm{mmol})$; (2) complete consumption of 1 ; (3) in ${ }^{29} \mathrm{Si} \mathrm{NMR}$, the two distinctive doublets centered at $97 \mathrm{ppm}$ were no longer visible; (4) in ${ }^{31} \mathrm{P} N M R$, the sharp singlet at $4.8 \mathrm{ppm}$ was no longer visible. Refer to s-63 for the ${ }^{1} \mathrm{H}$ NMR spectral data describing the experiment. Selected spectral data: ${ }^{1} \mathrm{H}$ NMR (500 $\left.\mathrm{MHz}, \mathrm{CD}_{2} \mathrm{Cl}_{2}\right) \delta 1.26$ (s), 1.11 (br s), 0.90. (br s); $\left.{ }^{29} \mathrm{Si} \mathrm{NMR} \mathrm{(99.3} \mathrm{MHz}, \mathrm{CD}_{2} \mathrm{Cl}_{2}\right) \delta$ 31.8, -7.0 (PhSiMe $),-57.9(1) ;{ }^{31} \mathrm{P}$ NMR (202 $\mathrm{MHz}$, $\left.\mathrm{CD}_{2} \mathrm{Cl}_{2}\right) \delta 32.1$ (br s), 22.0 (br s), 0.0 (br s). Attempts to purify the reaction mixture using flash chromatography were not successful.

\section{Demonstration of catalytic activity of silylsilver complex 8}

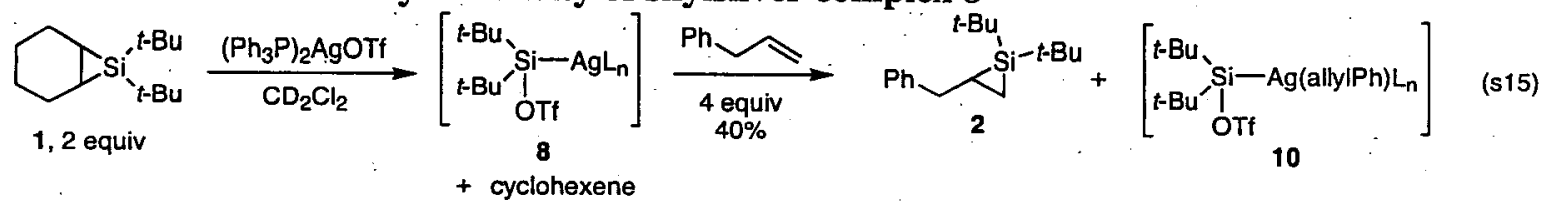

To a $25^{\circ} \mathrm{C}$ solution of cyclohexene silacyclopropane $1(0.0330 \mathrm{~g}, 0.147 \mathrm{mmol})$ and $\mathrm{PhSiMe}_{3}(0.010 \mathrm{~mL}, 0.0581$ mmol) in $0.300 \mathrm{~mL}$ of $\mathrm{CD}_{2} \mathrm{Cl}_{2}$ (contained in a valved $\mathrm{NMR}$ tube) was added a solution containing $0.0540 \mathrm{~g}$ $\left[\left(\mathrm{Ph}_{3} \mathrm{P}\right)_{2} \mathrm{AgOTf}\right]_{2}(0.0690 \mathrm{mmol} \mathrm{Ag})$ in $0.300 \mathrm{~mL} \mathrm{CD} \mathrm{Cl}_{2}$. After $3 \mathrm{~min}$, the resultant yellow solution was cooled to $-78^{\circ} \mathrm{C}$. After $20 \mathrm{~min}$, the reaction mixture was placed in a cool $\left(-40^{\circ} \mathrm{C}\right) \mathrm{NMR}$ spectrometer. Analysis of the ${ }^{1} \mathrm{H}$ and ${ }^{29} \mathrm{Si}$ NMR spectra revealed the formation of cyclohexene $\left(0.064 \mathrm{mmol}\right.$, relative to $\mathrm{PhSiMe}_{3}$ internal standard) and 8. The yellow reaction mixture was cooled to $-78{ }^{\circ} \mathrm{C}$ and $0.0350 \mathrm{~mL}$ of allylbenzene was added dropwise. Over $15 \mathrm{~h}$, the reaction mixture was warmed to $25^{\circ} \mathrm{C}$. Analysis of the reaction progress using ${ }^{1} \mathrm{H}$ NMR spectroscopy revealed complete consumption of cyclohexene silacyclopropane 1 and the formation of benzyl silacyclopropane $2(0.0575 \mathrm{mmol}, 40 \%)$. In addition to product 2 at -49.8 , analysis of the ${ }^{29} \mathrm{Si}$ NMR at $-20{ }^{\circ} \mathrm{C}$ revealed two doublets centered at $90.2 \mathrm{ppm}\left(J=372.5\left({ }^{109} \mathrm{Ag}-{ }^{29} \mathrm{Si}\right)\right.$ and $322.4\left({ }^{109} \mathrm{Ag}-{ }^{29} \mathrm{Si}\right) \mathrm{Hz}$; relative gyromagnetic ratio 1.155). Analysis using ${ }^{1} \mathrm{H}$ NMR spectroscopy of the reaction mixture $24 \mathrm{~h}$ later revealed no change in the concentration of 2 . Refer to s-64 and s-65 for the NMR spectral data describing the experiment.

\section{E. Behavior of benzyl silacyclopropane 2 with $\left(\mathrm{Ph}_{\mathbf{3}} \mathbf{P}\right)_{2} \mathrm{AgOTf}$

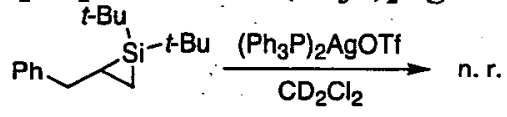 \\ (s16)

$$
\text { 2, } 2 \text { equiv }
$$

To a $25^{\circ} \mathrm{C}$ solution of benzyl silacyclopropane $2(0.0370 \mathrm{~g}, 0.142 \mathrm{mmol})$ and $\mathrm{PhSiMe}(0.0100 \mathrm{~mL}, 0.0581$ $\mathrm{mmol}$ ) in $0.300 \mathrm{~mL}$ of $\mathrm{CD}_{2} \mathrm{Cl}_{2}$ (contained in a valved $\mathrm{NMR}$ tube) was added a solution containing $0.0540 \mathrm{~g}$ $\left[\left(\mathrm{Ph}_{3} \mathrm{P}\right)_{2} \mathrm{AgOTf}\right]_{2}(0.0690 \mathrm{mmol} \mathrm{Ag})$ in $0.300 \mathrm{~mL} \mathrm{CD} \mathrm{Cl}_{2}$. Analysis of the reaction mixture using NMR spectroscopy revealed: (1) consumption of $2(0.0987 \mathrm{mmol}$ remained), (2) no formation of allylbenzene, (3) no formation of a silylsilver complex. Selected spectral data: ${ }^{1} \mathrm{H}$ NMR $\left(500 \mathrm{MHz}, \mathrm{CD}_{2} \mathrm{Cl}_{2}\right) \delta 7.00-7.70(\mathrm{~m}), 2.96$ $(\mathrm{m}, 2 \mathrm{H}, \mathrm{Bn}-\mathrm{H}), 1.89(\mathrm{~s}, 9 \mathrm{H}, t-\mathrm{Bu}), 1.10(\mathrm{~s}, 9 \mathrm{H}, t-\mathrm{Bu}), 1.00-1.15(\mathrm{~m}), 0.76(\mathrm{dd}, J=10.9,12.0 \mathrm{~Hz}, 1 \mathrm{H}), 0.29$ $(\mathrm{m}, 1 \mathrm{H}) ;{ }^{29} \mathrm{Si} \mathrm{NMR}\left(99.3 \mathrm{MHz}, \mathrm{CD}_{2} \mathrm{Cl}_{2}\right) \delta-3.8\left(\mathrm{PhSiMe}_{3}\right),-48.9(2) ;{ }^{31} \mathrm{P}$ NMR $\left(202 \mathrm{MHz}, \mathrm{CD}_{2} \mathrm{Cl}_{2}\right) \delta 12-16$ (br s). Spectral data was consistent with that expected for starting material. Refer to s-66 for the NMR spectral data describing the experiment. 


\section{Analysis of Possible Mechanisms}

The following section contains possible mechanisms and some comments on their relationship to the kinetic order data:

\section{ASSUMPTIONS:}

(1) catalyst exists in solution as: $\left(\mathrm{Ph}_{3} \mathrm{P}\right)_{2} \mathrm{AgOTf}(\text { styrene })_{2}$

(2) $\frac{\mathrm{d}[\mathrm{Ag}-\mathrm{sil}]}{\mathrm{dt}}=0$

$$
\left[\begin{array}{ll}
\mathrm{Ag} \text {-sil }= \\
t B \mathrm{Bu} \\
\mathrm{OTf}
\end{array}\right]
$$

Abbreviations:

cyclohexene silacyclopropane 1 styrene

$\left(\mathrm{Ph}_{3} \mathrm{P}\right)_{2} \mathrm{AgOTf}(\text { styrene })_{2}$ (catalyst) cyclohexene
KINETIC ORDER DATA:

- saturation behavior in catalyst concentration

- inverse saturation behavior in styrene concentration

- inverse saturation behavior in cyclohexene concentration

- first order in cyclohexene silacyclopropane concentration

The following rate law is implicated from these observations:

$$
\begin{aligned}
\frac{d[p d t]}{d t}= & \frac{x\left[c y \text { sin] }\left[A g(s t y)_{2}\right]\right.}{y[c y]+z[s t y]+w\left[A g(s t y)_{2}\right]} \text { OR } \\
\frac{d[p d t]}{d t}= & \frac{x[c y \text { sil }]\left[A g(s t y)_{2}\right][s t y]}{y[c y]+z[s t y]+w\left[A g(s t y)_{2}\right]} \\
& \text { where } x, y, z, w \text { are rate constants }
\end{aligned}
$$

\section{Possible Mechanisms}

Scheme s1. Silver-mediated extrusion and cyclization Mechanism I

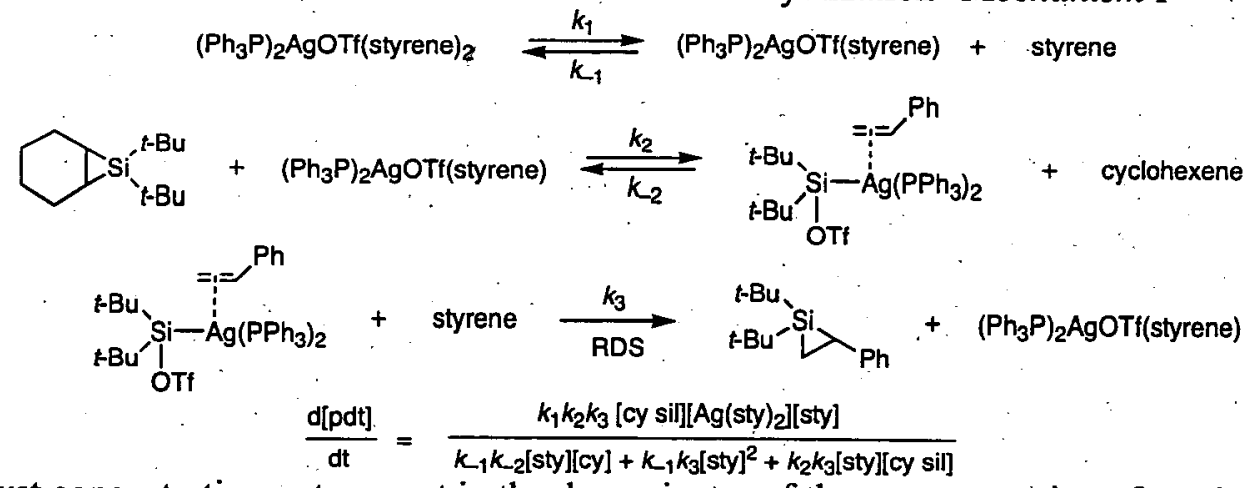

Problem: Catalyst concentration not present in the denominator of the rate expression of mechanism 1. 


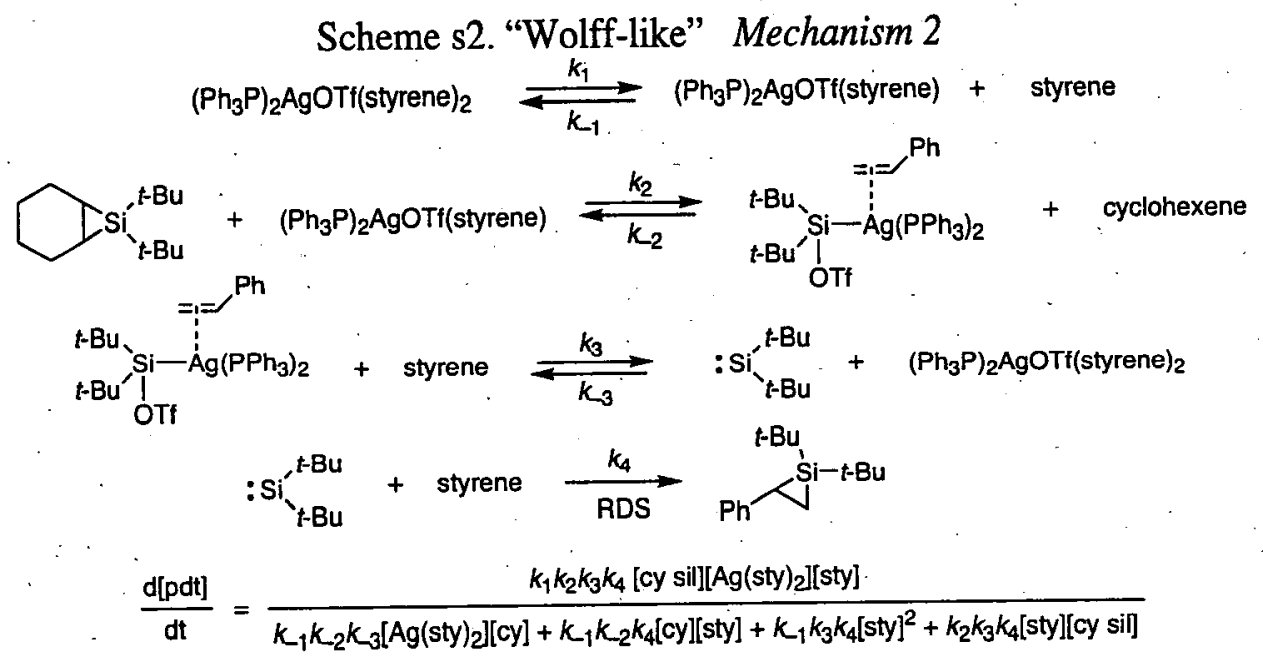

Problems: At high [styrene] concentrations expect that rate would go to 0 (i.e. from $1 /$ [sty]). Hammett data (vide infra) not consistent with that predicted from "metal-free" silylene transfer ( $\rho$ value different and reaction under enthalpic control).

Scheme s3. Silver-alkene as the nucleophile Mechanism 3

$$
\begin{aligned}
& \mathrm{CSi}_{\mathrm{t}-\mathrm{Bu}}^{t-\mathrm{Bu}} \stackrel{k_{1}}{\underset{k_{-1}}{\rightleftarrows}}: \mathrm{Si}_{\mathrm{t}-\mathrm{Bu}}^{t-\mathrm{Bu}}+\text { cyclohexene }
\end{aligned}
$$

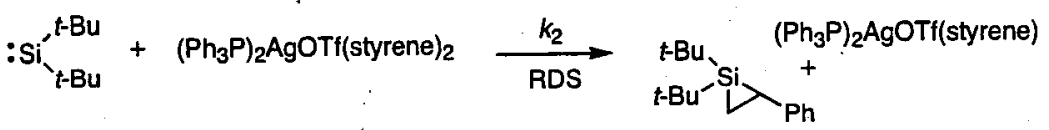

$$
\begin{aligned}
& \frac{d[p d t]}{d t}=\frac{k_{1} k_{2}[\mathrm{cy} \operatorname{si}]\left[\mathrm{Ag}(\mathrm{sty})_{2}\right]}{k_{1}[\mathrm{cy}]+k_{2}\left[\mathrm{Ag}(\mathrm{sty})_{2}\right]}
\end{aligned}
$$

Problems: While the rate expression of mechanism 3 contains [catalyst] dependence in numerator and denominator it does not contain any dependence on [styrene]. Mechanism 3 also does not explain $\mathrm{Ag}-\mathrm{Si}$ coupling observed in ${ }^{29} \mathrm{Si}$ NMR spectrum of the reactive intermediate.

$$
\begin{aligned}
& \text { Scheme s4. Silver as a trap for cyclohexene Mechanism } 4
\end{aligned}
$$

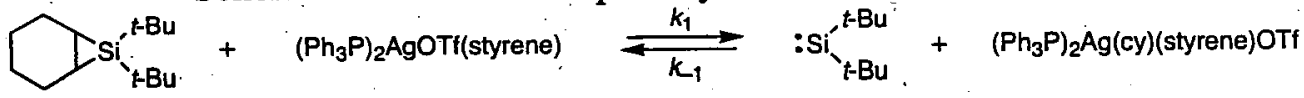

$$
\begin{aligned}
& : \mathrm{Si}_{\mathrm{t}-\mathrm{Bu}}^{\mathrm{t}-\mathrm{Bu}}+\text { styrene } \underset{\mathrm{RDS}}{\stackrel{k_{2}}{\longrightarrow}} \text { product } \\
& \frac{d[p d t]}{d t}=\frac{k_{1} k_{2}\left[c y \text { sin] }\left[\mathrm{Ag}(s t y)_{2}\right][s t y]\right.}{k_{1}[\mathrm{Ag}(\mathrm{cy})(\mathrm{sty})]+k_{2}[\mathrm{sty}]}
\end{aligned}
$$


Problems: Mechanism 4 would not be expected to show saturation by the catalyst, $\left[\mathrm{Ag}(\mathrm{sty})_{2}\right]$, since the silver species present in the denominator of the rate expression is $[\mathrm{Ag}(\mathrm{cy})(\mathrm{sty})]$. This mechanism also does not explain Ag-Si coupling observed in ${ }^{29} \mathrm{Si}$ NMR spectrum of intermediate.

Scheme s5. Pre-activation of cyclohexene silacyclopropane Mechanism 5

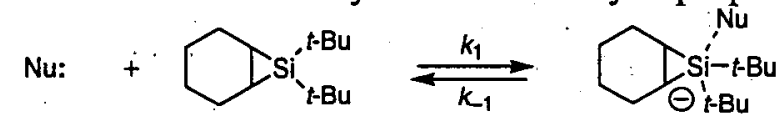
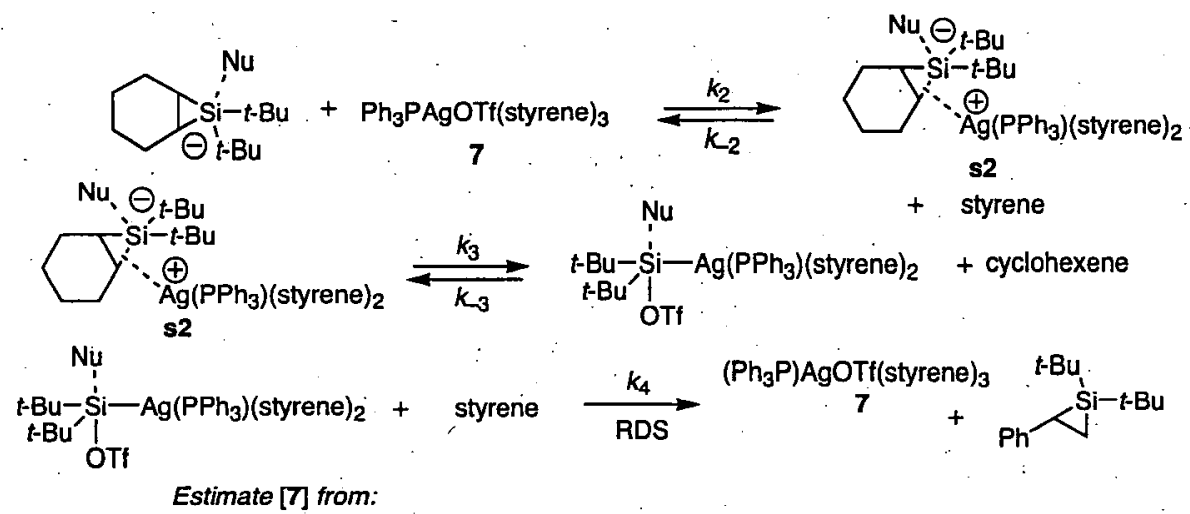

$\left.\left(\mathrm{Ph}_{3} \mathrm{P}\right)_{2} \mathrm{AgOTf(styrene}\right)_{2}$

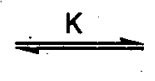

$\left(\mathrm{Ph}_{3} \mathrm{P}\right) \mathrm{AgOTf}$ (styrene) $)_{3}$

+ styrene

$+\mathrm{Ph}_{3} \mathrm{P}$

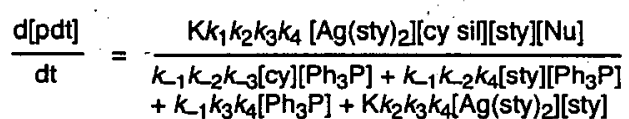

Problems: The rate law predicted for the pre-activation of cyclohexene silacyclopropane by styrene contains an order of two in [styrene] in the numerator, At high concentrations of styrene an order of one would be expected. When solvent is the nucleophile, the rate law is consistent with the data; however, the activation parameters do not vary from solvent to solvent (vide infra). When the nucleophile is triflate anion, the rate law appears to be consistent with the data. The concentration of triflate, however, is related to [catalyst] leading to a rate law that contains a kinetic order of two in $\left[\mathrm{Ag}(\mathbf{s t y})_{2}\right]$. Further, sigma complex $\mathbf{s} 2$ is not a low energy intermediate. The corresponding carbon analogue of $\mathbf{s} 2$ has only been theorized as a transition state leading to metallocyclobutanes. ${ }^{7}$ 
VII. Competition Experiments between substituted styrenes

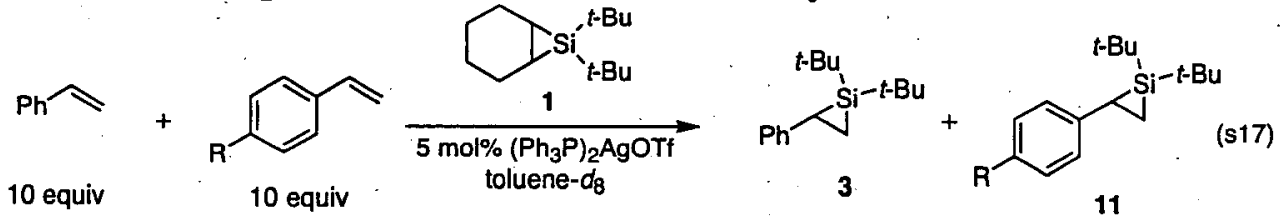

A. $\left(\mathrm{Ph}_{3} \mathrm{P}\right)_{2} \mathrm{AgOTf}$ : Linear correlation of $\log k_{\text {rel }}$ with Hammett equation using $\sigma_{\mathrm{p}}$ constants at $25^{\circ} \mathrm{C}$

The general procedure is illustrated for the reaction of styrene and 4-methoxyanisole with a deficient amount of cyclohexene silacyclopropane 1 at $25^{\circ} \mathrm{C}$ in the presence of $5 \mathrm{mol \%}\left(\mathrm{Ph}_{3} \mathrm{P}\right)_{2} \mathrm{AgOTf}$ (eq s17). To a solution containing $\left(\mathrm{Ph}_{3} \mathrm{P}\right)_{2}$ AgOTf $\left(0.0500 \mathrm{~mL}\right.$ of a $0.02896 \mathrm{M}$ suspension in toluene- $\left.d_{8}, 0.00149 \mathrm{mmol}\right)$ in $0.300 \mathrm{~mL}$ of a $0.02321 \mathrm{M}$ solution of $\mathrm{PhSiMe}_{3}$ in toluene- $d_{8}$ was added a solution containing $0.0340 \mathrm{~mL}$ of styrene $(0.290$ $\mathrm{mmol}), 0.0380 \mathrm{~mL}$ of $p$-methoxystyrene $(0.290 \mathrm{mmol}), 0.0650 \mathrm{~mL}$ of cyclohexene silacyclopropane $1(0.0290$ $\mathrm{mmol}$ ) in $0.210 \mathrm{~mL}$ of a $0.02321 \mathrm{M}$ solution of $\mathrm{PhSiMe}_{3}$ in toluene- $d_{8}$. After $70 \mathrm{~min}$, the reaction progress was measured using ${ }^{1} \mathrm{H}$ NMR spectroscopy. Each experiment was performed in triplicate. The $k_{\text {rel }}$ between substituted styrenes was obtained by comparison of the area of the standard $\left(\mathrm{PhSiMe}_{3}, \delta 0.199 \mathrm{ppm}\right.$, area set = 1.0000 ) and the area of their respective product aryl silacyclopropane $t$-Bu peaks (Table s6). Refer to s-67 - s80 for the ${ }^{1} \mathrm{H}$ NMR spectral data for each individual experimental run. Tables s6 - s8 and Figure s12 summarize the resultant data.

Table s6. Data for competition reactions between substituted styrenes at $25^{\circ} \mathrm{C}$ using $5 \mathrm{~mol} \%\left(\mathrm{Ph}_{3} \mathrm{P}\right)_{2} \mathrm{AgOTf}$

\begin{tabular}{|c|c|c|c|c|c|c|c|c|}
\hline \multirow{2}{*}{ Entry } & \multirow{2}{*}{$\mathbf{R}$} & \multicolumn{3}{|c|}{ Area of substituted aryl silacyclopropane 11 (ppm) } & \multicolumn{3}{|c|}{ Area of styrene silacyclopropane $3(\mathrm{ppm})$} & \multirow{2}{*}{$\begin{array}{l}\text { av } k_{\text {rel }} \\
( \pm S D)\end{array}$} \\
\hline & & Run 1 & . $\operatorname{Run} 2$ & Run 3 & Run 1 & Run 2 & Run 3 & \\
\hline 1 & OMe & $1.0612(0.896)$ & $1.0463(0.896)$ & $1.0238(0.896)$ & $0.9757(0.858)$ & $0.9248(0.857)$ & $0.9247(0.858)$ & $\begin{array}{c}1.107 \\
(0.018)\end{array}$ \\
\hline 2 & $\mathrm{Me}$ & 0.936 & $0.9543(0.888)$ & $0.9916(0.888)$ & $0.9771(0.858)$ & $0.9867(0.860)$ & $1.075(0.860)$ & $\begin{array}{c}0.949 \\
(0.019)\end{array}$ \\
\hline 3 & F & $0.8057(0.826)$ & $0.8221(0.827)$ & $0.7476(0.826)$ & $1.1325(0.858)$ & $1.1485(0.858)$ & $1.0959(0.858)$ & $\begin{array}{c}0.703 \\
(0.015)\end{array}$ \\
\hline 4 & $\mathrm{Cl}$ & $0.7062(0.807)$ & $0.7003(0.806)$ & $0.6758(0.807)$ & $1.2246(0.859)$ & $1.2357(0.857)$ & $1.1886(0.858)$ & $\begin{array}{c}0.571 \\
(0.0043)\end{array}$ \\
\hline 5 & $\mathrm{CF}_{3}$ & $0.4960(0.771)$ & $0.4967(0.771)$ & $0.4582(0.771)$ & $1.4257(0.857)$ & $1.4672(0.857)$ & $1.3791(0.858)$ & $\begin{array}{c}0.339 \\
(0.0064)\end{array}$ \\
\hline
\end{tabular}

Table s7. Correlation of $\log k_{\text {rel }}$ with o-constants

\begin{tabular}{cccc}
\hline Entry & 4-substituent & $\sigma$-constant & av $\log k_{\text {Tel }}( \pm$ std deviation $)$ \\
\hline 1 & $\mathrm{OMe}$ & -0.27 & $0.04477(0.0086)$ \\
2 & $\mathrm{Me}$ & -0.17 & $-0.02271(0.011)$ \\
3 & $\mathrm{~F}$ & 0.06 & $-0.1531(0.011)$ \\
4 & $\mathrm{Cl}$ & 0.23 & $-0.2436(0.0040)$ \\
5 & $\mathrm{CF}_{3}$ & 0.54 & $-0.4692(0.010)$ \\
\hline
\end{tabular}




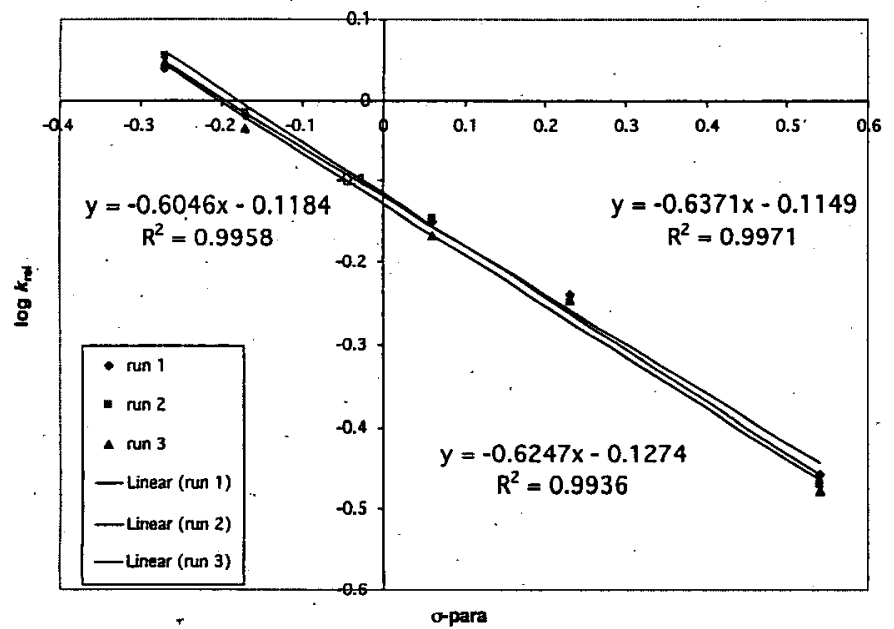

Table s8. Error determination in $p$ value

\begin{tabular}{|c|c|}
\hline rin & $\rho$ value \\
\hline 1 & -0.6046 \\
\hline 2 & -0.6247 \\
\hline 3 & -0.6371 \\
\hline average & -0.6221 \\
\hline std deviation & 0.016 \\
\hline
\end{tabular}

Figure s12. Individual linear correlation of $\log k_{\text {rel }}$ with o-constants at $25^{\circ} \mathrm{C}$

\section{B. $\left(\mathrm{Ph}_{3} \mathrm{P}\right)_{2} \mathrm{AgOTf}$ : Linear correlation of $\log k_{\text {rel }}$ with Hammett equation using $\sigma_{\mathrm{p}}$ constants at $8{ }^{\circ} \mathrm{C}$}

The general procedure is illustrated for the reaction of styrene and 4-methoxyanisole with a deficient amount of cyclohexene silacyclopropane 1 at $8{ }^{\circ} \mathrm{C}$ in the presence of $5 \mathrm{~mol} \%\left(\mathrm{Ph}_{3} \mathrm{P}\right)_{2} \mathrm{AgOTf}$. To a cold $\left(-78{ }^{\circ} \mathrm{C}\right)$ solution containing $0.0650 \mathrm{~mL}$ of cyclohexene silacyclopropane $1(0.0290 \mathrm{mmol})$ in $0.300 \mathrm{~mL}$ of a $0.02321 \mathrm{M}$ solution of $\mathrm{PhSiMe}_{3}$ in toluene- $d_{8}$ was added, dropwise, a solution containing $0.0340 \mathrm{~mL}$ of styrene $(0.290 \mathrm{mmol})$, $0.0380 \mathrm{~mL}$ of $p$-methoxystyrene $(0.290 \mathrm{mmol})$, and $\left(\mathrm{Ph}_{3} \mathrm{P}\right)_{2} \mathrm{AgOTf}(0.0500 \mathrm{~mL}$ of a $0.02896 \mathrm{M}$ suspension in toluene- $d_{8}, 0.00145 \mathrm{mmol}$ ) in $0.200 \mathrm{~mL}$ of a $0.02321 \mathrm{M}$ solution of $\mathrm{PhSiMe}_{3}$ in toluene- $d_{8}$. After thermal equilibration to $-78^{\circ} \mathrm{C}$, the resulting solution, was shaken five times. The reaction mixture was re-cooled to -78 ${ }^{\circ} \mathrm{C}$, and then it was placed in a cooled $\left(8^{\circ} \mathrm{C}\right)$ desiccator. After $14 \mathrm{~h}$ at $8{ }^{\circ} \mathrm{C}$, the reaction mixture was cooled to $-78^{\circ} \mathrm{C}$ and then it was placed in a cold $\left(-20^{\circ} \mathrm{C}\right) \mathrm{NMR}$ spectrometer. The reaction progress was measured using ${ }^{1} \mathrm{H}$ NMR spectroscopy. Each experiment was performed in triplicate. The $k_{\text {rel }}$ between substituted styrenes was obtained by comparison of the area of the standard $\left(\mathrm{PhSiMe}_{3}, \delta 0.199 \mathrm{ppm}\right.$, area set $\left.=1.0000\right)$ and the area of their respective product aryl silacyclopropane $t$-Bu peaks (Table s9). Refer to s-81-s-94 for the ${ }^{1} \mathrm{H}$ NMR spectral data for each individual experimental run. Tables s9-s11 and Figures s13 and s14 summarize the resultant data.

Table s9. Data for competition reactions between substituted styrenes at $8^{\circ} \mathrm{C}$ using 5 mol\% $\left(\mathrm{Ph}_{3} \mathrm{P}\right)_{2} \mathrm{AgOTf}$

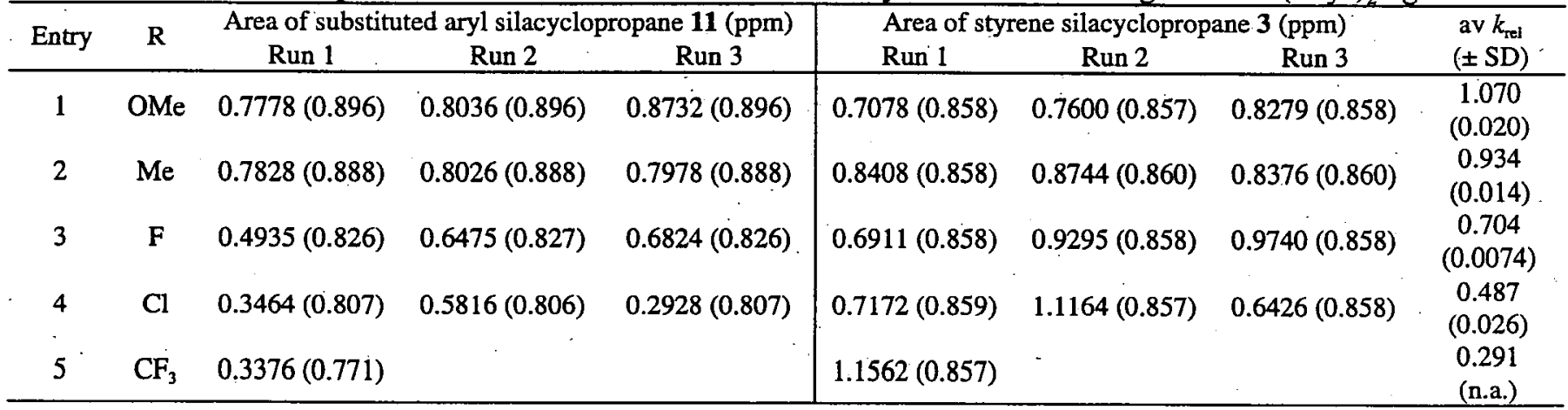


Table s10. Correlation of $\log k_{\text {rel }}$ with $\sigma$-constants $\left(8^{\circ} \mathrm{C}\right)$

\begin{tabular}{cccc}
\hline Entry & 4-substituent & $\sigma$-constant & av $\log k_{\text {rel }}$ ( \pm std deviation) \\
\hline 1 & $\mathrm{OMe}$ & -0.27 & $0.02910(0.010)$ \\
2 & $\mathrm{Me}$ & -0.17 & $-0.02980(0.0081)$ \\
3 & $\mathrm{~F}$ & 0.06 & $-0.1525(0.0056)$ \\
4 & $\mathrm{Cl}$ & 0.23 & $-0.3135(0.029)$ \\
5 & $\mathrm{CF}_{3}$ & 0.54 & -0.5373 (n.a.) \\
\hline
\end{tabular}

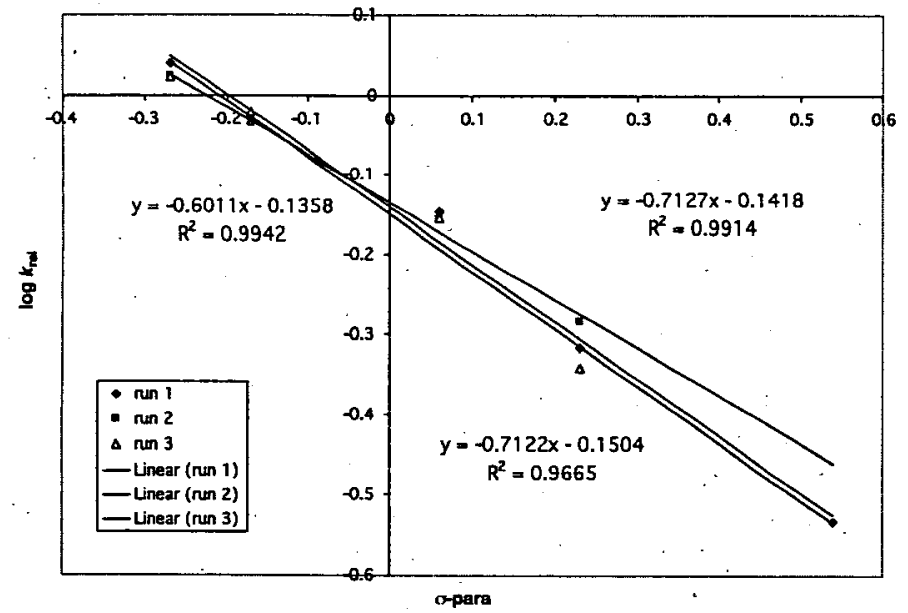

\begin{tabular}{cc} 
Table s11. Error determination in $\rho$ value \\
\hline run & $\rho$ value \\
\hline 1 & -0.6011 \\
2 & -0.7127 \\
3 & -0.7122 \\
\hline average & -0.6754 \\
std deviation & 0.065
\end{tabular}

Figure s13. Individual linear correlation of $\log k_{\text {rel }}$ with $\sigma$-constants at $8^{\circ} \mathrm{C}$

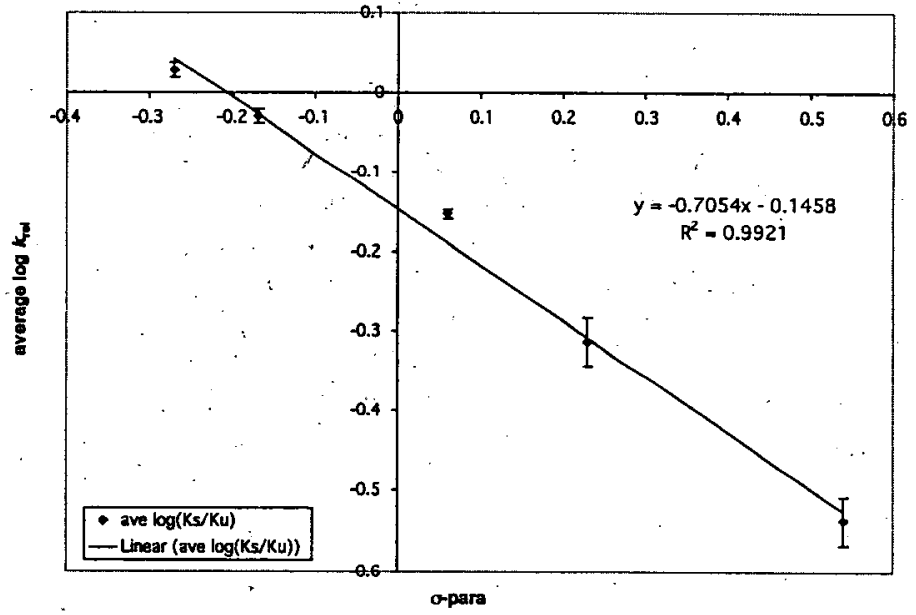

Figure s14. Linear correlation of $\log k_{\text {rel }}$ with $\sigma$-constants at $8^{\circ} \mathrm{C}$

\section{C. $\left(\mathrm{Ph}_{3} \mathrm{P}\right)_{2} \mathrm{AgOTf}$ : Linear correlation of $\log k_{\text {rel }}$ with Hammett equation using $\sigma_{\mathrm{p}}$ constants at $-8^{\circ} \mathrm{C}$}

The general procedure is illustrated for the reaction of styrene and 4-methoxyanisole with a deficient amount of cyclohexene silacyclopropane 1 at $8^{\circ} \mathrm{C}$ in the presence of $5 \mathrm{~mol} \%\left(\mathrm{Ph}_{3} \mathrm{P}\right)_{2} \mathrm{AgOTf}$. To a cold $\left(-78^{\circ} \mathrm{C}\right)$ solution containing $0.0650 \mathrm{~mL}$ cyclohexene silacyclopropane $1(0.0290 \mathrm{mmol})$ in $0.300 \mathrm{~mL}$ of a $0.02321 \mathrm{M}$ solution of $\mathrm{PhSiMe}_{3}$ in toluene- $d_{8}$ was added, dropwise, a solution containing $0.0340 \mathrm{~mL}$ of styrene $(0.290 \mathrm{mmol}), 0.0380$ $\mathrm{mL}$ of $p$-methoxystyrene $(0.290 \mathrm{mmol})$, and $\left(\mathrm{Ph}_{3} \mathrm{P}\right)_{2} \mathrm{AgOTf}(0.0500 \mathrm{~mL}$ of a $0.02896 \mathrm{M}$ suspension in toluene- 
(C) 2004 American Chemical Society, J. Am. Chem. Soc., Driver ja0306563 Supporting Info Page 22

Supporting Information: Tom G. Driver and K. A. Woerpel

$d_{8}, 0.00145 \mathrm{mmol}$ ) in $0.200 \mathrm{~mL}$ of a $0.02321 \mathrm{M}$ solution of $\mathrm{PhSiMe}_{3}$ in toluene- $d_{8}$. After thermal equilibration to $-78^{\circ} \mathrm{C}$, the resulting solution was shaken 5 times. The reaction mixture was re-cooled to $-78^{\circ} \mathrm{C}$, and then it was transferred to a cryocool and warmed to $-8{ }^{\circ} \mathrm{C}$. After $48 \mathrm{~h}$, the reaction mixture was cooled to $-78^{\circ} \mathrm{C}$, and then it was placed in a cool $\left(-20^{\circ} \mathrm{C}\right) \mathrm{NMR}$ spectrometer. The reaction progress was measured using ${ }^{1} \mathrm{H}$ NMR spectroscopy. Each experiment was performed in triplicate. The $k_{\text {rel }}$ between substituted styrenes was obtained by comparison of the area of the standard $\left(\mathrm{PhSiMe}_{3}, \delta 0.199 \mathrm{ppm}\right.$, area set $\left.=1.0000\right)$ and the area of their respective product aryl silacyclopropane $t$-Bu peaks (Table s12). Refer to s-95 - s-109 for the ${ }^{1} \mathrm{H}$ NMR spectral data for each individual experimental run. Tables s12 - s14 and Figures s15 and s16 summarize the resultant data.

Table s12. Data for competition reactions between substituted styrenes at $-8{ }^{\circ} \mathrm{C}$ using $5 \mathrm{~mol} \%\left(\mathrm{Ph}_{3} \mathrm{P}\right)_{2} \mathrm{AgOTf}$

\begin{tabular}{|c|c|c|c|c|c|c|c|c|}
\hline \multirow{2}{*}{ Entry } & \multirow{2}{*}{$\mathbf{R}$} & \multicolumn{3}{|c|}{ Area of substituted aryl silacyclopropane $11(\mathrm{ppm})$} & \multicolumn{3}{|c|}{ Area of styrene silacyclopropane $3(\mathrm{ppm})$} & \multirow{2}{*}{$\begin{array}{l}\text { av } k_{\text {rel }} \\
( \pm \mathrm{SD})\end{array}$} \\
\hline & & Run 1 & Run 2 & Run 3 & Run 1 & Run 2 & Run 3 & \\
\hline 1 & $\mathrm{OMe}$ & $0.1600(0.898)$ & $0.3709(0.898)$ & $0.3632(0.898)$ & $0.1207(0.859)$ & $0.3256(0.859)$ & $0.3218(0.859)$ & $\begin{array}{c}1.198 \\
(0.090)\end{array}$ \\
\hline 2 & Me & $0.4142(0.889)$ & $0.3099(0.889)$ & $0.3094(0.889)$ & $0.3980(0.861)$ & $0.2781(0.861)$ & $0.3094(0.862)$ & $\begin{array}{c}1.064 \\
(0.035)\end{array}$ \\
\hline 3 & $\mathbf{F}$ & 0.2326( & $0.2835(0.827)$ & $0.2063(0.827)$ & $0.3236(0.859)$ & $0.4000(0.858)$ & $0.2964(0.859)$ & $\begin{array}{c}0.708 \\
(0.0093)\end{array}$ \\
\hline 4 & $\mathrm{Cl}$ & $0.2017(0.807)$ & $0.2099(0.807)$ & $0.1544(0.806)$ & $0.4440(0.859)$ & $0.5157(0.859)$ & $0.3403(0.859)$ & $\begin{array}{c}0.438 \\
(0.022)\end{array}$ \\
\hline 5 & $\mathrm{CF}_{3}$ & $0.1176(0.771)$ & $0.1147(0.771)$ & $0.1167(0.771)$ & $0.4277(0.858)$ & $0.4211(0.858)$ & $0.4100(0.857)$ & $\begin{array}{c}0.277 \\
(0.005)\end{array}$ \\
\hline
\end{tabular}

Table s13. Correlation of $\log k_{\text {rel }}$ with $\sigma$-constants $\left(-8^{\circ} \mathrm{C}\right)$

\begin{tabular}{cccc}
\hline Entry & 4-substituent & $\sigma$-constant & \\
\hline 1 & $\mathrm{OMe}$ & -0.27 & av $\log k_{\text {rel }}$ ( \pm std deviation) \\
2 & $\mathrm{Me}$ & -0.17 & $0.07718(0.039)$ \\
3 & $\mathrm{~F}$ & 0.06 & $0.02651(0.0018)$ \\
4 & $\mathrm{Cl}$ & 0.23 & $-0.1501(0.0070)$ \\
5 & $\mathrm{CF}_{3}$ & 0.54 & $-0.3586(0.027)$ \\
\hline
\end{tabular}

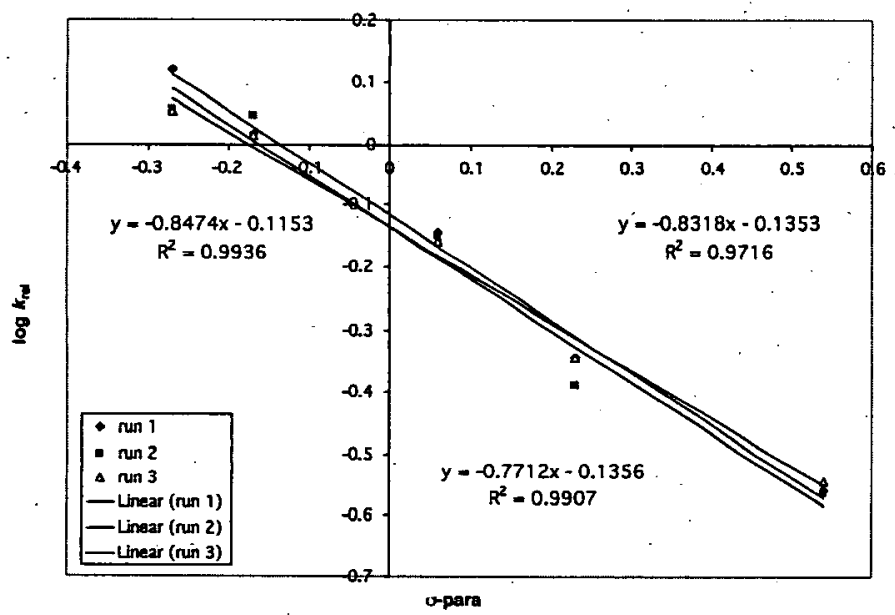

Table s14. Error determination in $\rho$ value

\begin{tabular}{cc}
\hline run & $\rho$ value \\
\hline 1 & -0.8474 \\
2 & -0.8318 \\
3 & -0.7712 \\
\hline average & -0.8168 \\
std deviation & 0.040
\end{tabular}

Figure s15. Individual linear correlation of $\log k_{\text {rel }}$ with $\sigma$-constants at $-8{ }^{\circ} \mathrm{C}$ 


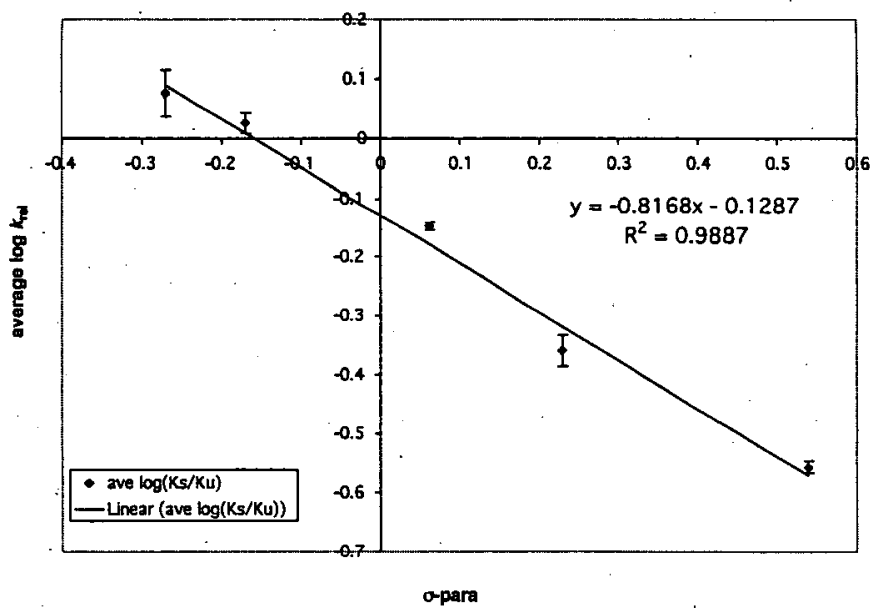

Figure s16. Linear correlation of $\log k_{\text {rel }}$ with $\sigma$-constants at $-8^{\circ} \mathrm{C}$

\section{Theoretical determination of isokinetic temperature}

Figure s17 illustrates the linear relationship observed between temperature and the experimentally determined $\rho$ values, which allowed for the theoretical determination of an isokinetic temperature to be $129{ }^{\circ} \mathrm{C}$.

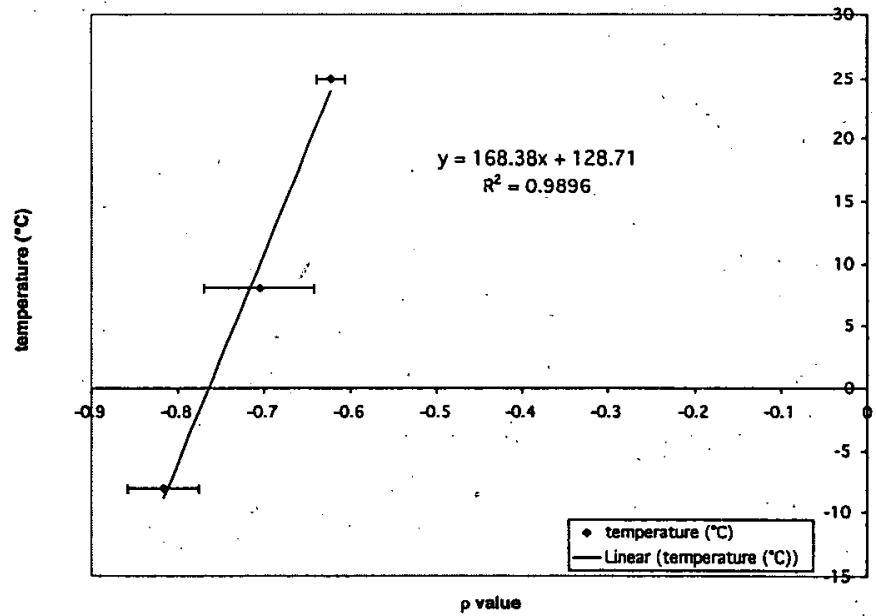

Figure s17. Linear correlation between temperature $\left({ }^{\circ} \mathrm{C}\right)$ and experimentally determined $\rho$ values

E. AgOTf: Linear correlation of $\log k_{\text {rel }}$ with Hammett equation using $\sigma_{\mathrm{p}}$ constants at $25^{\circ} \mathrm{C}$
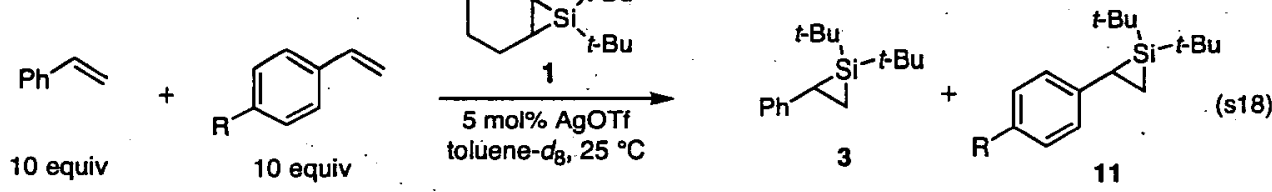

The general procedure is illustrated for the reaction of styrene and 4-methoxyanisole with a deficient amount of cyclohexene silacyclopropane 1 at $25^{\circ} \mathrm{C}$ in the presence of 5 mol\% AgOTf (eq s18). To a solution containing AgOTf $\left(0.0500 \mathrm{~mL}\right.$ of a $0.02896 \mathrm{M}$ suspension in toluene- $\left.d_{8}, 0.00145 \mathrm{mmol}\right)$ in $0.300 \mathrm{~mL}$ of a $0.02321 \mathrm{M}$ solution of $\mathrm{PhSiMe}_{3}$ in toluene- $d_{8}$ was added a solution containing $0.0340 \mathrm{~mL}$ of styrene $(0.290 \mathrm{mmol}), 0.0380$ 
$\mathrm{mL}$ of $p$-methoxystyrene $(0.290 \mathrm{mmol})$, and $0.0650 \mathrm{~mL}$ cyclohexene silacyclopropane $1(0.0290 \mathrm{mmol})$ in $0.210 \mathrm{~mL}$ of a $0.02321 \mathrm{M}$ solution of $\mathrm{PhSiMe}_{3}$ in toluene- $d_{8}$. After $70 \mathrm{~min}$, the reaction progress was measured using ${ }^{1} \mathrm{H}$ NMR spectroscopy. Each experiment was performed in triplicate. The $k_{\text {rel }}$ between substituted styrenes was obtained by comparison of the area of the standard $\left(\mathrm{PhSiMe}_{3}, \delta 0.199 \mathrm{ppm}\right.$, area set $\left.=1.0000\right)$ and the area of their respective product aryl silacyclopropane $t$-Bu peaks (Table s15). Refer to s-110 - s-124 for the ${ }^{1} \mathrm{H}$ NMR spectral data for each individual experimental run. Tables s15 - s17 and Figures s18 and s19 summarize the resultant data.

Table s15. Data for competition reactions between substituted styrenes at $-8{ }^{\circ} \mathrm{C}$ using $5 \mathrm{~mol} \%$ AgOTf

\begin{tabular}{|c|c|c|c|c|c|c|c|c|}
\hline \multirow{2}{*}{ Entry } & \multirow{2}{*}{$\mathbf{R}$} & \multicolumn{3}{|c|}{ Area of substituted aryl silacyclopropane 11 (ppm) } & \multicolumn{3}{|c|}{ Area of styrene silacyclopropane $3(\mathrm{ppm})$} & \multirow{2}{*}{$\begin{array}{l}\text { av } k_{\text {rel }} \\
( \pm \mathrm{SD})\end{array}$} \\
\hline & & Run 1 & Run 2 & Run 3 & Run 1 & Run 2 & Run 3 & \\
\hline 1 & $\mathrm{OMe}$ & $0.9144(0.898)$ & $0.8951(0.898)$ & $0.8748(0.898)$ & $0.8313(0.859)$ & $0.7875(0.859)$ & $0.7698(0.859)$ & $\begin{array}{c}1.124 \\
(0.021)\end{array}$ \\
\hline 2 & $\mathrm{Me}$ & $0.8875(0.889)$ & $0.9244(0.889)$ & $0.8194(0.889)$ & $0.9385(0.861)$ & $0.9573(0.861)$ & $0.8436(0.862)$ & $\begin{array}{c}0.961 \\
(0.013)\end{array}$ \\
\hline 3 & F & $0.7578(0.827)$ & $0.7804(0.827)$ & $0.8595(0.827)$ & $1.1386(0.859)$ & $1.2317(0.859)$ & $1.1549(0.859)$ & $\begin{array}{c}0.681 \\
(0.057)\end{array}$ \\
\hline 4 & $\mathrm{Cl}$ & $1.2148(0.807)$ & $1.1370(0.807)$ & $1.0480(0.806)$ & $1.8643(0.859)$ & $1.8953(0.857)$ & $1.7890(0.859)$ & $\begin{array}{c}0.612 \\
(0.035)\end{array}$ \\
\hline 5 & $\mathrm{CF}_{3}$ & $0.5788(0.771)$ & $0.5987(0.771)$ & $0.6441(0.771)$ & $1.5965(0.858)$ & $1.6694(0.857)$ & $1.7448(0.857)$ & $\begin{array}{c}0.363 \\
(0.0053)\end{array}$ \\
\hline
\end{tabular}

Table s16. Correlation of $\log k_{\text {rel }}$ with o-constants $\left(-8^{\circ} \mathrm{C}\right)$

\begin{tabular}{cccc}
\hline Entry & 4-substituent & $\sigma$-constant & av $\log k_{\text {rel }}$ ( std deviation) \\
\hline 1 & OMe & -0.27 & $0.04477(0.0086)$ \\
2 & $\mathrm{Me}$ & -0.17 & $-0.01736(0.0061)$ \\
3 & $\mathrm{~F}$ & 0.06 & $-0.1678(0.036)$ \\
4 & $\mathrm{Cl}$ & 0.23 & $-0.2134(0.024)$ \\
5 & $\mathrm{CF}_{3}$ & 0.54 & $-0.4396(0.0063)$ \\
\hline
\end{tabular}

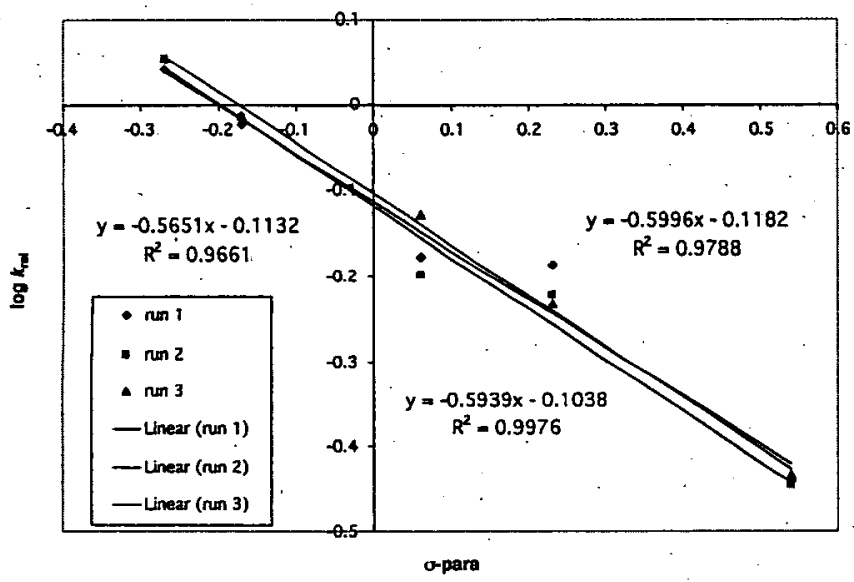

Figure s18. Individual linear correlation of $\log k_{\text {rel }}$ with $\sigma$-constants at $25^{\circ} \mathrm{C}$ with $5 \mathrm{~mol} \%$ AgOTf
Table s17. Error determination in $\rho$ value

\begin{tabular}{cc}
\hline run & $\rho$ value \\
\hline 1 & -0.5610 \\
2 & -0.5979 \\
3 & -0.5845 \\
\hline average & -0.5862 \\
std deviation & 0.018
\end{tabular}




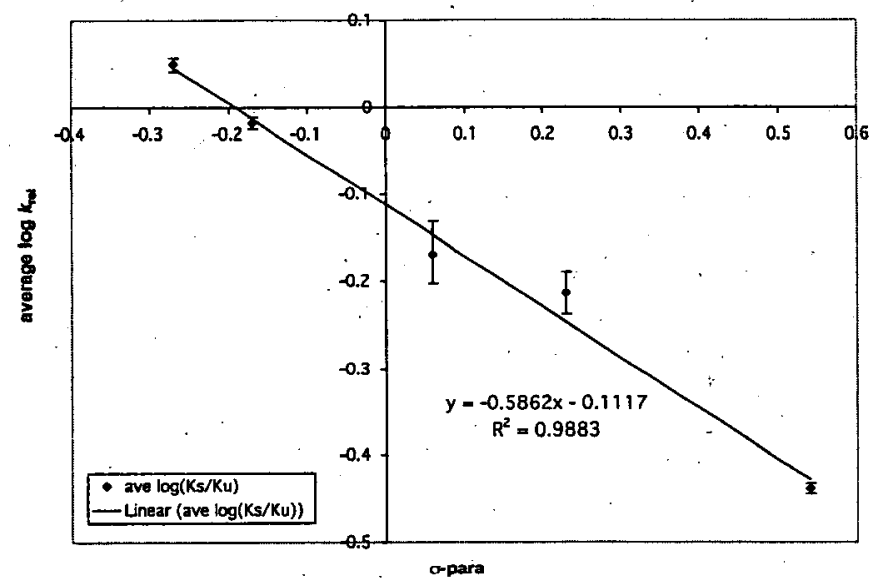

Figure s19. Linear correlation of $\log k_{\text {rel }}$ with $\sigma$-constants at $25^{\circ} \mathrm{C}$ with 5 mol\% AgOTf

F. (CuOTf $)_{2} \cdot \mathrm{PhH}$ : Linear correlation of $\log k_{\text {rel }}$ with Hammett equation using $\sigma_{\mathrm{p}}$ constants at $25^{\circ} \mathrm{C}$<smiles>[2H]c1ccc(C=Cc2ccc(C(C)(C)C)cc2)cc1</smiles>

The general procedure is illustrated for the reaction of styrene and 4-methoxyanisole with a deficient amount of cyclohexene silacyclopropane 1 at $25^{\circ} \mathrm{C}$ in the presence of $2.5 \mathrm{~mol} \%(\mathrm{CuOTf})_{2} \cdot \mathrm{PhH}$ (eq s19). To a solution containing (CuOTf $)_{2} \cdot \mathrm{PhH}\left(0.0500 \mathrm{~mL}\right.$ of a $0.02896 \mathrm{M}$ suspension in toluene- $\left.d_{8}, 0.00145 \mathrm{mmol}\right)$ in $0.300 \mathrm{~mL}$ of a $0.02321 \mathrm{M}$ solution of $\mathrm{PhSiMe}_{3}$ in toluene- $d_{8}$ was added a solution containing $0.0340 \mathrm{~mL}$ of styrene $(0.290$ $\mathrm{mmol}), 0.0380 \mathrm{~mL}$ of $p$-methoxystyrene $(0.290 \mathrm{mmol})$, and $0.0650 \mathrm{~mL}$ cyclohexene silacyclopropane $1(0.0290$ $\mathrm{mmol}$ ) in $0.210 \mathrm{~mL}$ of a $0.02321 \mathrm{M}$ solution of $\mathrm{PhSiMe}_{3}$ in toluene- $d_{8}$. After $70 \mathrm{~min}$, the reaction progress was measured using ${ }^{1} \mathrm{H}$ NMR spectroscopy. Each experiment was performed in triplicate. The $k_{\text {rel }}$ between substituted styrenes was obtained by comparison of the area of the standard $\left(\mathrm{PhSiMe}_{3}, \delta 0.199 \mathrm{ppm}\right.$, area set $=$ 1.0000 ) and the area of their respective product aryl silacyclopropane $t$-Bu peaks (Table s18). Refer to s-125 s-139 for the ${ }^{1} \mathrm{H}$ NMR spectral data for each individual experimental run. Tables s18 - s20 and Figures s20 and s21 summarize the resultant data.

Table s18. Data for competition reactions between substituted styrenes at $25^{\circ} \mathrm{C}$ using $2.5 \mathrm{~mol} \%(\mathrm{CuOTf})_{2} \cdot \mathrm{PhH}$

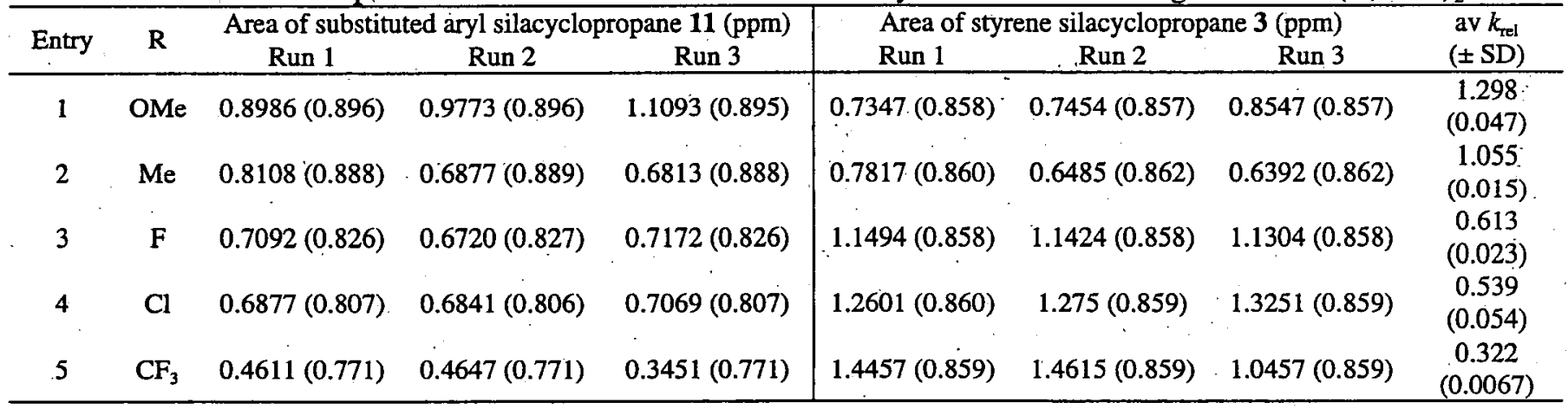


Table s19. Correlation of $\log k_{\text {rel }}$ with $\sigma$-constants

\begin{tabular}{cccc}
\hline Entry & 4-substituent & $\sigma$-constant & av $\log k_{\text {rel }}$ ( std deviation $)^{8}$ \\
\hline 1 & OMe & -0.27 & $0.1124(0.0057)$ \\
2 & $\mathrm{Me}$ & -0.17 & $0.02302(0.0062)$ \\
3 & $\mathrm{~F}$ & 0.06 & $-0.2126(0.017)$ \\
4 & $\mathrm{Cl}$ & 0.23 & $-0.2689(0.0051)$ \\
5 & $\mathrm{CF}_{3}$ & 0.54 & $-0.4918(0.0090)$ \\
\hline
\end{tabular}

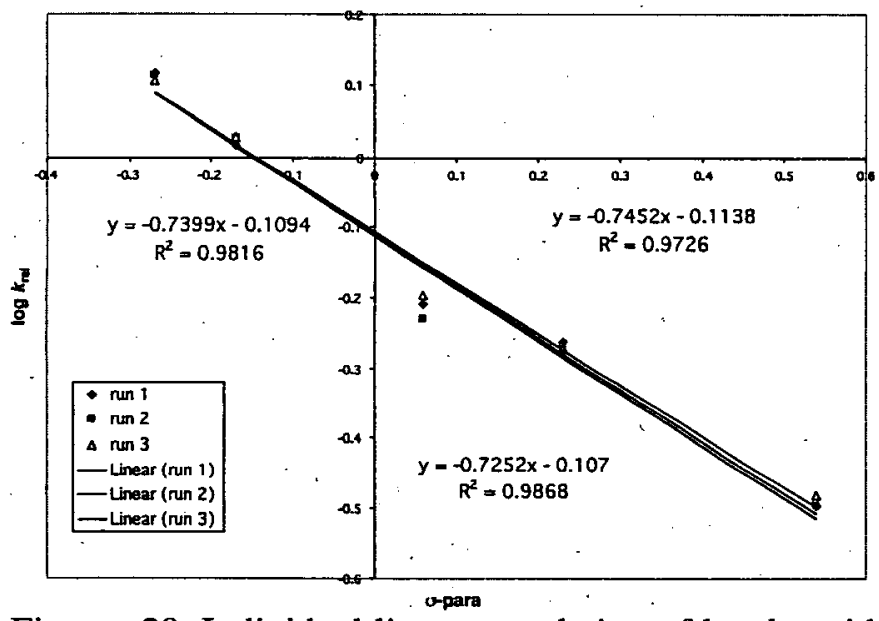

Table s20. Error determination in $\rho$ value

\begin{tabular}{cc}
\hline run & $\rho$ value \\
\hline 1 & -0.7399 \\
2 & -0.7452 \\
3 & -0.7252 \\
\hline average & -0.7368 \\
std deviation & 0.010
\end{tabular}

Figure s20. Individual linear correlation of $\log k_{\text {rel }}$ with $\sigma$ constants at $25^{\circ} \mathrm{C}$ with $2.5 \mathrm{~mol} \%$ (CuOTf) $2 \cdot \mathrm{PhH}$

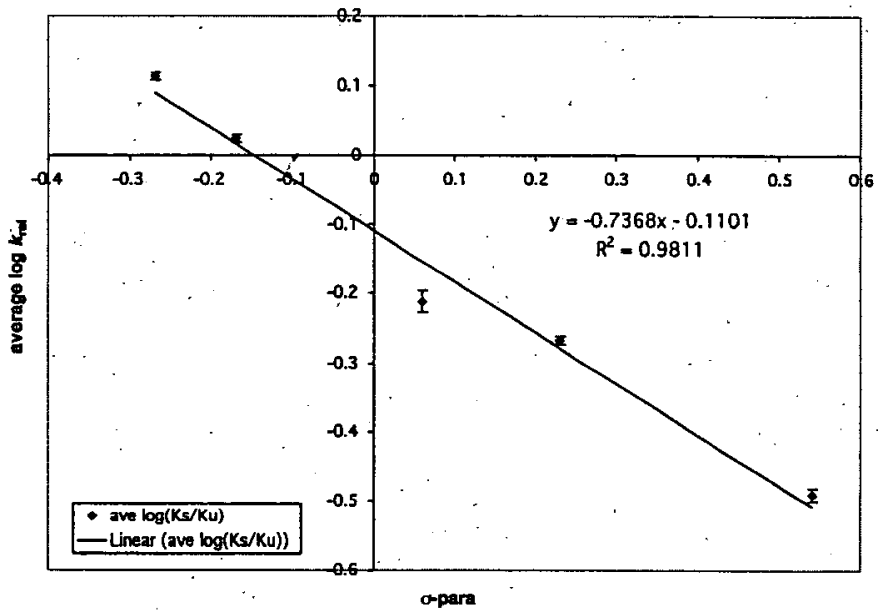

Figure s21. Linear correlation of $\log k_{\text {rel }}$ with $\sigma$-constants at $25^{\circ} \mathrm{C}$ with $2.5 \mathrm{~mol} \%(\mathrm{CuOTf})_{2} \cdot \mathrm{PhH}$

G. Ph ${ }_{3} \mathrm{PAuCl}$ : Linear correlation of $\log k_{\text {ret }}$ with Hammett equation using $\sigma_{\mathrm{p}}$ constants at $25^{\circ} \mathrm{C}$<smiles>C=Cc1ccc(P)cc1</smiles>

10 equiv

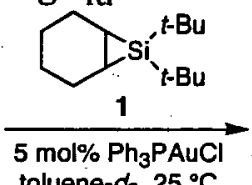

toluene- $d_{8}, 25^{\circ} \mathrm{C}$

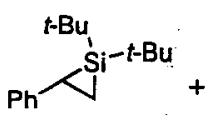

3

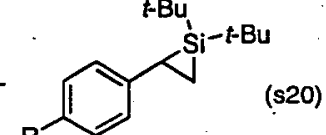

11

The general procedure is illustrated for the reaction of excess styrene and 4-methoxyanisole with cyclohexene silacyclopropane 1 at $25^{\circ} \mathrm{C}$ in the presence of $5 \mathrm{~mol}^{\circ} \mathrm{Ph}_{3} \mathrm{PAuCl}$ (eq s20). To a solution containing $\mathrm{Ph}_{3} \mathrm{PAuCl}$ 
$\left(0.0500 \mathrm{~mL}\right.$ of a $0.02896 \mathrm{M}$ suspension in toluene- $\left.d_{8}, 0.00145 \mathrm{mmol}\right)$ in $0.300 \mathrm{~mL}$ of a $0.02321 \mathrm{M}$ solution of $\mathrm{PhSiMe}_{3}$ in toluene- $d_{8}$ was added a solution containing $0.0340 \mathrm{~mL}$ of styrene $(0.290 \mathrm{mmol}), 0.0380 \mathrm{~mL}$ of $p$ methoxystyrene $(0.290 \mathrm{mmol})$, and $0.0650 \mathrm{~mL}$ cyclohexene silacyclopropane $1(0.0290 \mathrm{mmol})$ in $0.210 \mathrm{~mL}$ of a $0.02321 \mathrm{M}$ solution of $\mathrm{PhSiMe}{ }_{3}$ in toluene- $d_{8}$. After $70 \mathrm{~min}$, the reaction progress was measured using ${ }^{1} \mathrm{H} \cdot \mathrm{NMR}$ spectroscopy. Each experiment was performed in triplicate. The $k_{\text {rel }}$ between substituted styrenes was obtained by comparison of the area of the standard $\left(\mathrm{PhSiMe}_{3}, \delta 0.199 \mathrm{ppm}\right.$, area set $\left.=1.0000\right)$ and the area of their respective product aryl silacyclopropane $t$-Bu peaks (Table s21). Refer to $s-140-s-154$ for the ${ }^{1} \mathrm{H}$ NMR spectral data for each individual experimental run. Tables s21 - s23 and Figures s22 and s23 summarize the resultant data.

Table s21. Data for competition reactions between substituted styrenes at $25^{\circ} \mathrm{C}$ using $5 \mathrm{~mol} \% \mathrm{Ph}_{3} \mathrm{PAuCl}$

\begin{tabular}{|c|c|c|c|c|c|c|c|c|}
\hline \multirow{2}{*}{ Entry } & \multirow{2}{*}{$\mathbf{R}$} & \multicolumn{3}{|c|}{ Area of substituted aryl silacyclopropane 11 (ppm) } & \multicolumn{3}{|c|}{ Area of styrene silacyclopropane 3 (ppm) } & \multirow{2}{*}{$\begin{array}{l}\text { av } k_{\text {rel }} \\
( \pm \mathrm{SD})\end{array}$} \\
\hline & & Run 1 & Run 2 & Run 3 & Run 1 & Run 2 & Run 3 & \\
\hline 1 & $\mathrm{OMe}$ & $1.0684(0.897)$ & $1.1385(0.897)$ & $1.1355(0.897)$ & $0.9608(0.858)$ & $0.9105(0.858)$ & $0.9948(0.858)$ & $\begin{array}{c}1.120 \\
(0.018)\end{array}$ \\
\hline 2 & $\mathrm{Me}$ & $1.000(0.889)$ & $0.3973(0.890)$ & $1.175(0.889)$ & $1.0286(0.862)$ & $0.4215(0.862)$ & $1.2373(0.862)$ & $\begin{array}{l}0.9548 \\
(0.015)\end{array}$ \\
\hline 3 & $\mathbf{F}$ & $0.9287(0.826)$ & $2.0864(0.827)$ & $0.9067(0.827)$ & $1.2067(0.858)$ & $2.8484(0.858)$ & $1.1745(0.859)$ & $\begin{array}{c}0.758 \\
(0.022)\end{array}$ \\
\hline 4 & $\mathrm{Cl}$ & $0.0866(0.807)$ & $0.0851(0.806)$ & $0.066(0.807)$ & $0.1337(0.859)$ & $0.1262(0.857)$ & $0.1051(0.858)$ & $\begin{array}{c}0.650 \\
(0.023)\end{array}$ \\
\hline 5 & $\mathrm{CF}_{3}$ & $0.9835(0.771)$ & $1.0875(0.771)$ & $0.9665(0.771)$ & $2.5292(0.858)$ & $2.8611(0.857)$ & $2.5496(0.857)$ & $\begin{array}{c}0.379 \\
(0.00051)\end{array}$ \\
\hline
\end{tabular}

Table s22. Correlation of $\log k_{\text {rei }}$ with $\sigma$-constants

\begin{tabular}{cccc}
\hline Entry & 4-substituent & $\sigma$-constant & \\
\hline 1 & $\mathrm{OMe}$ & -0.27 & av $\log k_{\text {rel }}( \pm$ std deviation $)$ \\
2 & $\mathrm{Me}$ & -0.17 & $0.05038(0.0066)$ \\
3 & $\mathrm{~F}$ & 0.06 & $-0.02012(0.0070)$ \\
4 & $\mathrm{Cl}$ & 0.23 & $-0.1204(0.013)$ \\
5 & $\mathrm{CF}_{3}$ & 0.54 & $-0.1873(0.015)$ \\
\hline
\end{tabular}

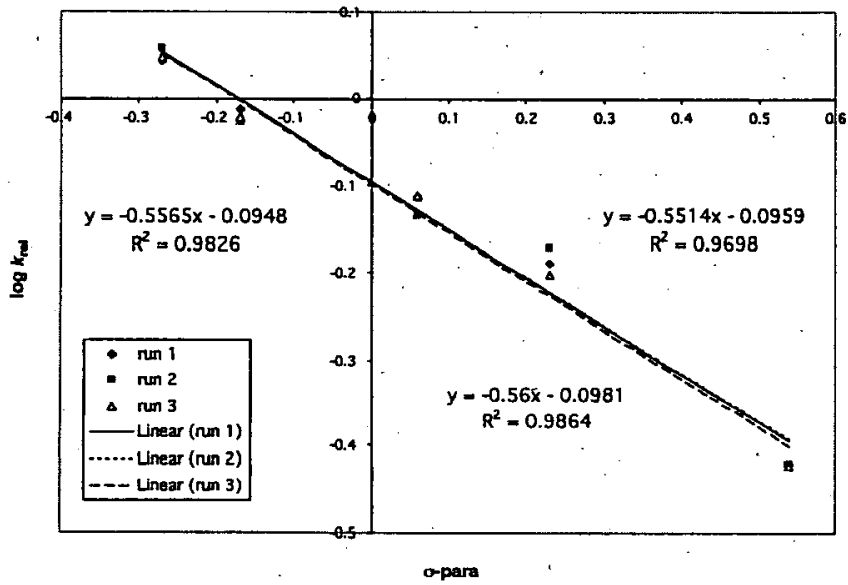

Table s23. Error determination in $\rho$ value

\begin{tabular}{cc}
\hline run & $\rho$ value \\
\hline 1 & -0.5565 \\
2 & -0.5514 \\
3 & -0.5600 \\
\hline average & -0.5559 \\
std deviation & 0.004
\end{tabular}

Figure s22. Individual linear correlation of $\log k_{\text {rel }}$ with $\sigma$-constants at $25^{\circ} \mathrm{C}$ with $5 \mathrm{~mol} \% \mathrm{Ph}_{3} \mathrm{PAuCl}$ 


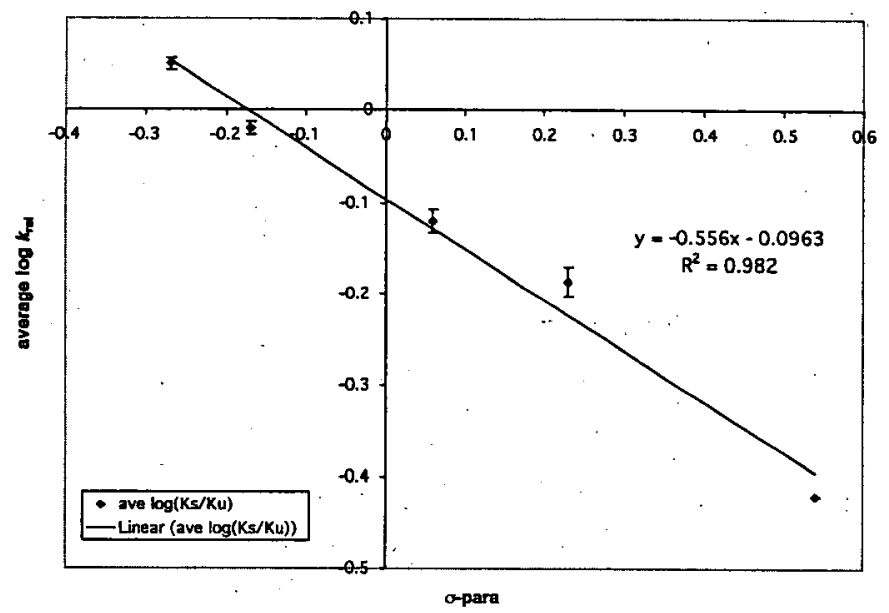

Figure s23. Linear correlation of $\log k_{\text {rel }}$ with $\sigma$-constants at $25^{\circ} \mathrm{C}$ with $5 \mathrm{~mol} \% \mathrm{Ph}_{3} \mathrm{PAuCl}$

VIII. Competition experiments between cyclic and acyclic alkenes<smiles>[13CH3][Si]([14CH3])([SiH3])C1CCCCC1</smiles>

1

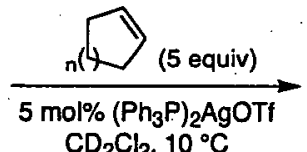

$\mathrm{CD}_{2} \mathrm{Cl}_{2}, 10^{\circ} \mathrm{C}$

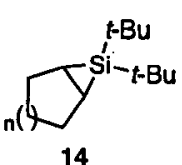

(s21)

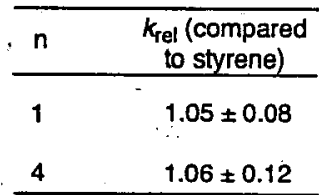

The general procedure is illustrated for the reaction of cyclooctene and cyclohexene silacyclopropane 1 in the presence of $5 \mathrm{~mol} \%\left(\mathrm{Ph}_{3} \mathrm{P}\right)_{2} \mathrm{AgOTf}$ at $10{ }^{\circ} \mathrm{C}$ (eq s21). To a cool $\left(-78{ }^{\circ} \mathrm{C}\right)$ solution of cyclohexene silacyclopropane $1\left(0.0650 \mathrm{~mL}\right.$ of a $0.4455 \mathrm{M}$ solution in $\left.\mathrm{CD}_{2} \mathrm{Cl}_{2}, 0.0290 \mathrm{mmol}\right)$ in $0.300 \mathrm{~mL}$ of a $0.0174 \mathrm{M}$ solution of $\mathrm{PhSiMe}_{3}$ in $\mathrm{CD}_{2} \mathrm{Cl}_{2}$ (contained in a thin wall NMR tube) was added, dropwise, a solution containing cyclooctene $(0.0380 \mathrm{~mL}, 0.290 \mathrm{mmol})$ and $\left(\mathrm{Ph}_{3} \mathrm{P}\right)_{2}$ AgOTf $\left(0.050 \mathrm{~mL}\right.$ of a $0.02896 \mathrm{M}$ solution in $\mathrm{CD}_{2} \mathrm{Cl}_{2}$, $0.00145 \mathrm{mmol}$ ) in $0.250 \mathrm{~mL}$ of a $0.0174 \mathrm{M}$ solution of $\mathrm{PhSiMe}_{3}$ in $\mathrm{CD}_{2} \mathrm{Cl}_{2}$. After thermal equilibration to -78 ${ }^{\circ} \mathrm{C}$, the reaction mixture was shaken five times. The reaction mixture was re-cooled to $-78^{\circ} \mathrm{C}$, and then it was placed in a cool $\left(-20^{\circ} \mathrm{C}\right) \mathrm{NMR}$ spectrometer. An initial ${ }^{1} \mathrm{H}$ NMR spectrum was obtained, and the temperature of the spectrometer was regulated to $10^{\circ} \mathrm{C}$. Periodically, the reaction progress was measured relative to the internal standard of $\mathrm{PhSiMe}_{3}$ using ${ }^{1} \mathrm{H} \mathrm{NMR}$ spectroscopy. Each experiment was performed in triplicate. The concentrations of the reactants and products were obtained by comparison of the area of the standard $\left(\mathrm{PhSiMe}_{3}\right.$, $\delta 0.23 \mathrm{ppm}$; area $=1.0000)$ and the area of the $t$-Bu peaks of the silacyclopropanes 1 and $14(1, \delta 1.20 \mathrm{ppm} ; 14$ $(n=1), \delta 1.03 \mathrm{ppm} ; 14(\mathrm{n}=4), \delta 1.15 \mathrm{ppm})$. The data was fit to the best straight line using a least-squares program to obtain $k_{\text {init }}$ values. The $k_{\text {rel }}(\mathbf{1 4 : 3})$ was determined through comparison to the $k_{\text {init }}$ values obtained for styrene silacyclopropane 3 . The procedure was repeated using cyclopentene in place of cyclooctene. A sample plot (Figure s24) from an experimental run is included below. Table s24 summarizes the results. 


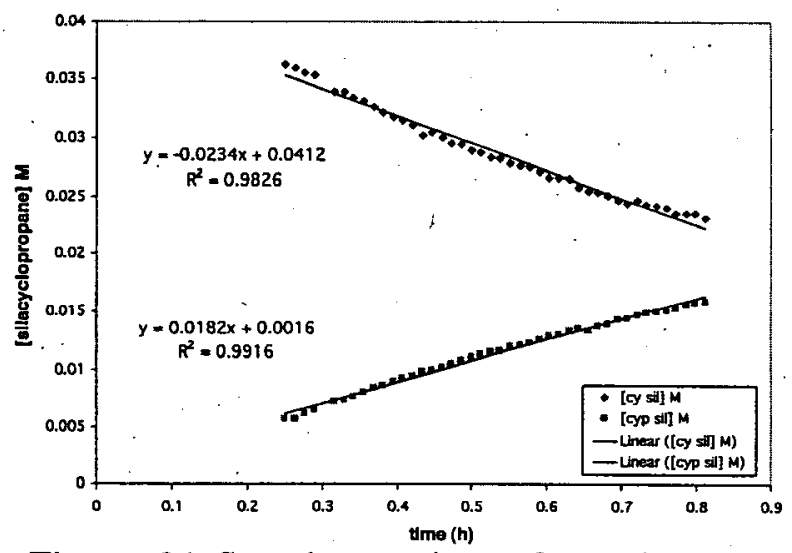

Figure s24. Sample experiment for cyclopentene

Table s24. Summary of data used in the estimation of $k_{\text {ret }}$ between cyclohexene and styrene

\begin{tabular}{ccccccccc}
\hline \multirow{2}{*}{ Entry } & \multirow{2}{*}{ alkene } & \multicolumn{2}{c}{$k_{\text {init }}\left(\times 10^{-6} \mathrm{M} / \mathrm{s}\right)\left(\mathrm{r}^{2}\right.$-value $)$} & av $k_{\text {init }}$ & Error (std & \multirow{2}{*}{$k_{\text {rel }}(14: 3)$} & \multirow{2}{*}{ Error } \\
\hline 1 & styrene & $4.61(0.9954)$ & $5.17(0.9956)$ & $4.86(0.9933)$ & 4.88 & 0.28 & n.a. & n.a. \\
2 & cyclopentene & $5.42(0.9898)$ & $4.83(0.9844)$ & $5.06(0.9916)$ & 5.10 & 0.29 & 1.05 & 0.08 \\
3 & cyclooctene & $4.63(0.9853)$ & $5.75(0.9822)$ & $5.19(0.9853)$ & 5.19 & 0.56 & 1.06 & 0.12 \\
\hline
\end{tabular}

\section{Determination of Activation Parameters in $\mathrm{CD}_{2} \mathrm{Cl}_{2}$ and toluene- $d_{8}$}

\section{A. Experimental Procedure}

The general procedure is illustrated for the reaction of styrene and cyclohexene silacyclopropane 1 in the presence of $5 \mathrm{~mol} \%\left(\mathrm{Ph}_{3} \mathrm{P}\right)_{2} \mathrm{AgOTf}$ at $10{ }^{\circ} \mathrm{C}$. To a cool $\left(-78{ }^{\circ} \mathrm{C}\right)$ solution of cyclohexene silacyclopropane 1 $\left(0.0650 \mathrm{~mL}\right.$ of a $0.4455 \mathrm{M}$ solution in $\left.\mathrm{CD}_{2} \mathrm{Cl}_{2}, 0.0290 \mathrm{mmol}\right)$ in $0.300 \mathrm{~mL}$ of a $0.0174 \mathrm{M}$ solution of $\mathrm{PhSiMe}_{3}$ in $\mathrm{CD}_{2} \mathrm{Cl}_{2}$ (contained in a thin wall NMR tube) was added, dropwise, a solution containing styrene $(0.0170 \mathrm{~mL}$, $0.145 \mathrm{mmol})$ and $\left(\mathrm{Ph}_{3} \mathrm{P}\right)_{2} \mathrm{AgOTf}\left(0.050 \mathrm{~mL}\right.$ of a $0.02896 \mathrm{M}$ solution in $\left.\mathrm{CD}_{2} \mathrm{Cl}_{2}, 0.00145 \mathrm{mmol}\right)$ in $0.270 \mathrm{~mL}$ of a $0.0174 \mathrm{M}$ solution of $\mathrm{PhSiMe}_{3}$ in $\mathrm{CD}_{2} \mathrm{Cl}_{2}$. After thermal equilibration to $-78^{\circ} \mathrm{C}$, the reaction mixture was shaken five times. The reaction mixture was re-cooled to $-78{ }^{\circ} \mathrm{C}$, and then it was placed in a cool $\left(-10^{\circ} \mathrm{C}\right)$ NMR spectrometer. An initial ${ }^{1} \mathrm{H}$ NMR spectrum was obtained, and the temperature of the experiment was regulated to $32^{\circ} \mathrm{C}$. Periodically, over five half lives the reaction progress was measured relative to the internal standard of $\mathrm{PhSiMe}_{3}$ using ${ }^{1} \mathrm{H}$ NMR spectroscopy. Each experiment was performed in triplicate. The concentrations of the reactants and products were obtained by comparison of the area of the standard $\left(\mathrm{PhSiMe}_{3}\right.$ $\delta 0.23 \mathrm{ppm}$; area $=1.0000)$ and the area of the $t$-Bu peaks of the silacyclopropanes 1 and $3(1, \delta 1.20 \mathrm{ppm} ; 3, \delta$ $0.83 \mathrm{ppm})$. The data was fit to the best straight line using a least-squares program to obtain $k_{\text {init }}$ values. The procedure was repeated at 24,17 , and $10^{\circ} \mathrm{C}$. The procedure was also repeated in toluene- $d_{8}$ at $40,33,25$, and $17^{\circ} \mathrm{C}$. Sample plots (Figure s25-s28) from two experimental runs (one for $\mathrm{CD}_{2} \mathrm{Cl}_{2}$ and one for toluene- $d_{8}$ ) are included below. Tables $\mathbf{2 5}$ and s26 summarize the results. 


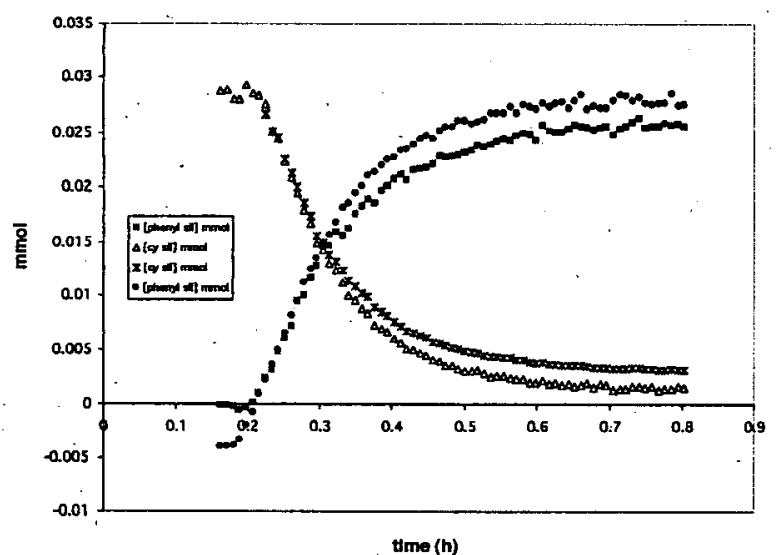

Figure s25. Reaction Progress at $24^{\circ} \mathrm{C}$ in $\mathrm{CD}_{2} \mathrm{Cl}_{2}$

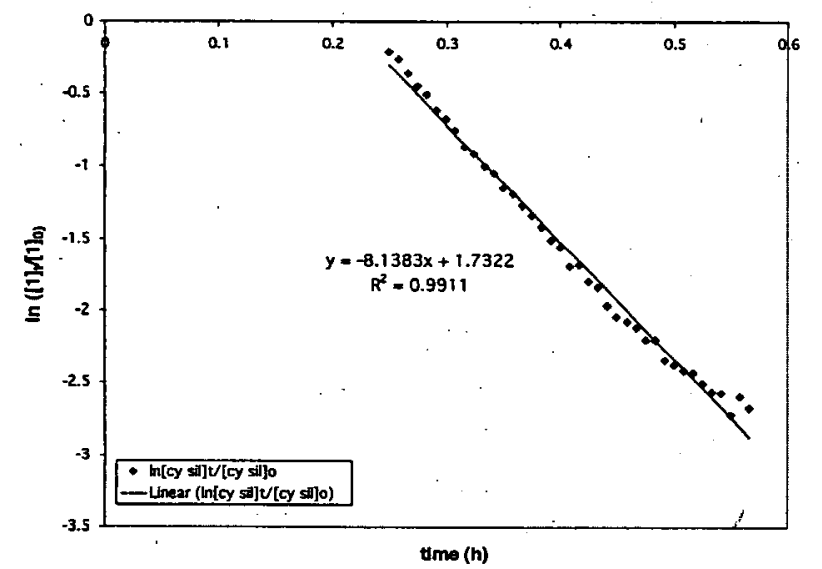

Figure s27. Determination of $k_{\mathrm{obs}}$ at $24^{\circ} \mathrm{C}$ in $\mathrm{CD}_{2} \mathrm{Cl}_{2}$

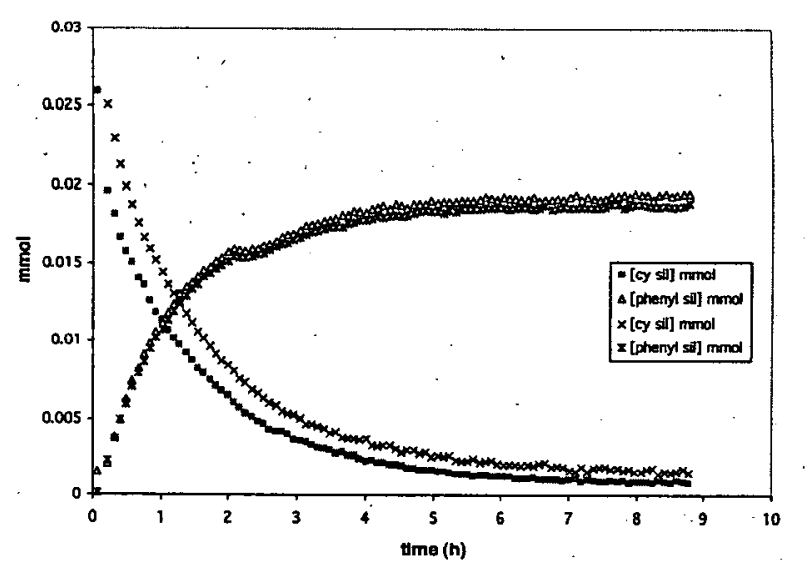

Figure s26. Reaction Progress at $10^{\circ} \mathrm{C}$ in toluene- $d_{8}$

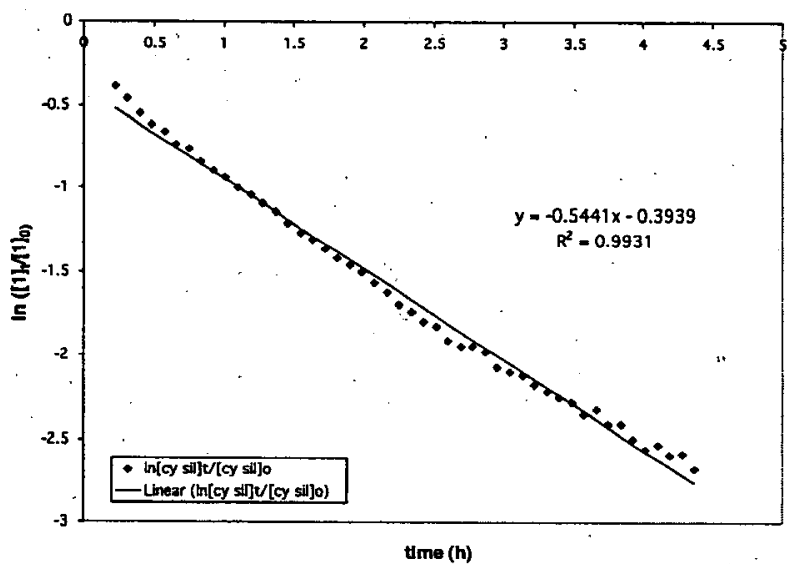

Figure s28. Determination of $k_{\text {obs }}$ at $10^{\circ} \mathrm{C}$ in toluene- $d_{8}$

Table s25. Summary of temperature dependence of $k_{\mathrm{obs}}$ in $\mathrm{CD}_{2} \mathrm{Cl}_{2}$

\begin{tabular}{cccccc}
\hline Entry & $\begin{array}{c}\text { Temperature } \\
\left({ }^{\circ} \mathrm{C}\right)\end{array}$ & Run 1 & $\begin{array}{c}k_{\text {obs }}\left(\times 10^{-3} \mathrm{~s}^{-1}\right)\left(\mathrm{r}^{2}-\text { value }\right) \\
\text { Run 2 }\end{array}$ & Run 3 & $\begin{array}{c}\text { av } k_{\text {obs }}\left(\times 10^{-3} \mathrm{~s}^{-1}\right) \\
( \pm \text { std deviation })\end{array}$ \\
\hline 1 & 32 & $5.11(0.9923)$ & $6.37(0.9912)$ & $6.55(0.9903)$ & $6.01(0.7)$ \\
2 & 24 & $2.29(0.9942)$ & $2.29(0.9970)$ & $2.26(0.9910)$ & $2.28(0.02)$ \\
3 & 17 & $0.538(0.9916)$ & $0.553(0.9893)$ & $0.442(0.9913)$ & $0.511(0.06)$ \\
4 & 10 & $0.144(0.9853)$ & $0.144(0.9904)$ & $0.148(0.9921)$ & $0.145(0.002)$ \\
\hline
\end{tabular}

Table s26. Summary of temperature dependence of $k_{\mathrm{obs}}$ in toluene- $d_{8}$

\begin{tabular}{|c|c|c|c|c|c|}
\hline \multirow{2}{*}{ Entry } & \multirow{2}{*}{$\begin{array}{c}\text { Temperature } \\
\left({ }^{\circ} \mathrm{C}\right)\end{array}$} & \multicolumn{3}{|c|}{$k_{\text {obs }}\left(\times 10^{-5} \mathrm{~s}^{-1}\right)\left(\mathrm{r}^{2}-\right.$ value $)$} & \multirow{2}{*}{$\begin{array}{l}\text { av } k_{\text {obs }}\left(\times 10^{-5} \mathrm{~s}^{-1}\right) \\
\text { ( } \mathrm{std} \text { deviation) }\end{array}$} \\
\hline & & Run 1 & Run 2 & Run 3 & \\
\hline 1 & 40 & $6.77(0.9930)$ & $6.73(0.9968)$ & $7.19(0.9976)$ & $6.90(0.2)$ \\
\hline 2 & 33 & $2.74(0.9859)$ & $2.61(0.9952)$ & $2.70(0.9894)$ & $2.69(0.06)$ \\
\hline 3 & 25 & $0.653(0.9926)$ & $0.660(0.9858)$ & $0.642(0.9940)$ & $0.652(0.009)$ \\
\hline 4 & 17 & $0.151(0.9931)$ & $0.147(0.9876)$ & $0.149(0.9827)$ & $0.149(0.002)$ \\
\hline
\end{tabular}


(C) 2004 American Chemical Society, J. Am. Chem. Soc., Driver ja0306563 Supporting Info Page 31

Supporting Information: Tom G. Driver and K. A. Woerpel

B. Derivation of Eyring Activation parameters

$$
\begin{gathered}
\text { Erying Equation: } \ln \left(\frac{k_{\mathrm{obs}}}{\mathrm{T}}\right)=\frac{\Delta \mathrm{S}^{\ddagger}}{\mathrm{R}}+\ln \left(\frac{k}{h}\right)-\left(\frac{\Delta \mathrm{H}^{\ddagger}}{\mathrm{RT}}\right) \\
\text { Where } k=1.380658 \mathrm{E}-23 \mathrm{~J} / \mathrm{K} \\
h=6.626 \mathrm{E}-34 \mathrm{~J} / \mathrm{s} ; \mathrm{R}=1.987 \mathrm{cal} /(\mathrm{mol} \cdot \mathrm{K})
\end{gathered}
$$

Table s27. Conversion of temperature and $k_{\mathrm{obs}}$ for use in Eyring equation (in $\mathrm{CD}_{2} \mathrm{Cl}_{2}$ )

\begin{tabular}{cccccc}
\hline Entry & $1 / \mathrm{T}\left(\times 10^{-3} \mathrm{~K}^{-1}\right)$ & Run 1 & $\begin{array}{l}\ln \left(k_{\text {obs }} / \mathrm{T}\right) \\
\text { Run 2 }\end{array}$ & $\begin{array}{c}\operatorname{Run} 3 \\
\text { ( } 1 \text { std deviation })\end{array}$ \\
\hline 1 & 3.29 & -10.99 & -10.77 & -10.75 & $-10.83(0.1)$ \\
2 & 3.37 & -11.77 & -11.77 & -11.79 & $-11.78(0.008)$ \\
3 & 3.45 & -13.20 & -13.17 & -13.39 & $-13.25(0.1)$ \\
4 & 3.53 & -14.49 & -14.49 & -14.47 & $-14.48(0.01)$ \\
\hline
\end{tabular}

Table s28. Conversion of temperature and $k_{\mathrm{obs}}$ for use in Eyring equation (in toluene- $d_{8}$ )

\begin{tabular}{cccccc}
\hline Entry & $1 / \mathrm{T}\left(\times 10^{-3} \mathrm{~K}^{-1}\right)$ & Run 1 & $\begin{array}{l}\ln \left(k_{\mathrm{obs}} / \mathrm{T}\right) \\
\text { Run 2 }\end{array}$ & Run 3 & $\begin{array}{c}\ln \left(\mathrm{av} k_{\mathrm{obs}} / \mathrm{T}\right) \\
\text { ( } \pm \text { std deviation })\end{array}$ \\
\hline 1 & 3.19 & -10.74 & -10.75 & -10.68 & $-10.72(0.04)$ \\
2 & 3.27 & -11.62 & -11.67 & -11.64 & $-11.64(0.02)$ \\
3 & 3.36 & -13.03 & -13.02 & -13.05 & $-13.03(0.01)$ \\
4 & 3.45 & -14.47 & -14.49 & -14.48 & $-14.48(0.01)$ \\
\hline
\end{tabular}

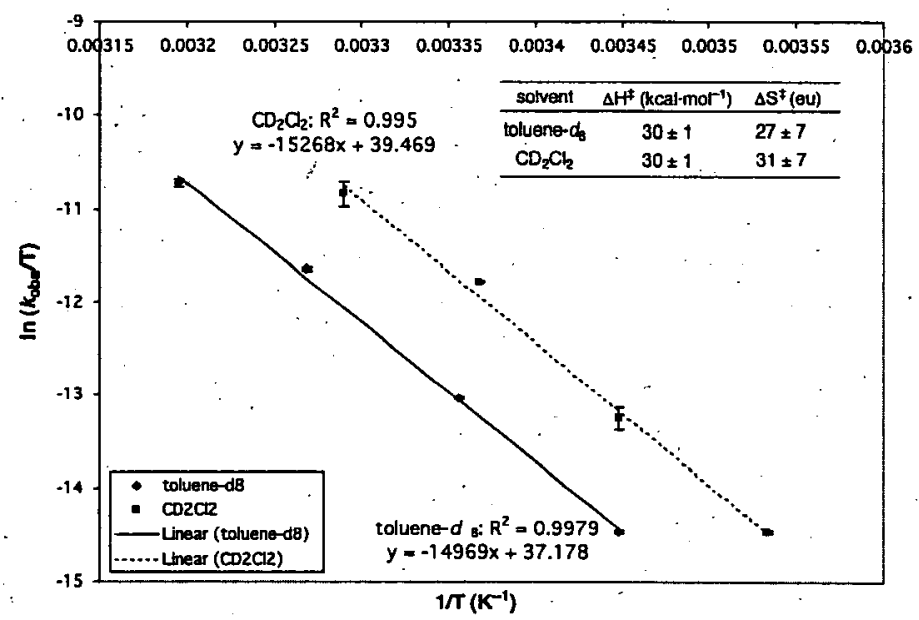

Figure s29. Linear correlation between $1 / \mathrm{T}$ and $\ln \left(-k_{\mathrm{obs}} \mathrm{T}\right)$

\section{Determination of error in Activation Parameters ${ }^{9,10}$}

Error Propagation Formulas: ${ }^{9 \mathrm{a}}$

$$
\left(\sigma \Delta H^{\ddagger}\right)^{2}=\frac{R^{2} T_{\max }^{2} T_{\min }^{2}}{\Delta T^{2}}\left\{\left(\frac{\sigma T}{T}\right)^{2}\left[\left(1+T_{\min } \frac{\Delta L}{\Delta T}\right)^{2}+\left(1+T_{\max } \frac{\Delta L}{\Delta T}\right)^{2}\right]^{2}+2\left(\frac{\sigma k_{(\mathrm{ran})}}{k}\right)^{2}+\left(\frac{\sigma k_{(\mathrm{yys})}}{k}\right)^{2}\right\}
$$


$\left(\sigma \Delta S^{\ddagger}\right)^{2}=\frac{R^{2}}{\Delta T^{2}}\left\{\left(\frac{\sigma T}{T}\right)^{2}\left[T_{\max }^{2}\left(1+T_{\min } \frac{\Delta L}{\Delta T}\right)^{2}+T_{\min }^{2}\left(1+T_{\max } \frac{\Delta L}{\Delta T}\right)^{2}\right]+\left[\left(\frac{\sigma k_{(\operatorname{ran})}}{k}\right)^{2}+\left(\frac{\sigma k_{(\mathrm{sys})}}{k}\right)^{2}\right]\left(T_{\max }^{2}+T_{\min }^{2}\right)\right\}$

where $\Delta T=\left(T_{\max }-T_{\min }\right)$ and $\Delta L=\left[\ln \left(k_{\max } / T_{\max }\right)-\ln \left(k_{\min } / T_{\min }\right)\right.$

and $\sigma k_{\text {(sys) }}$ was estimated to be ca. $5 \%$ based on subjective judgments of integration sensitivities ${ }^{8 a}$.

\section{Derivation of Arrhenius Activation Parameters}

Arrhenius Equation: $\ln k=\ln \mathrm{A}-\left(\frac{E_{\mathrm{a}}}{R}\right) \frac{1}{\mathrm{~T}}$

Where $R=1.987 \mathrm{cal} /(\mathrm{mol} \cdot \mathrm{K})$

Table s29. Conversion of temperature and $k_{\mathrm{obs}}$ for use in Arrhenius equation (in $\mathrm{CD}_{2} \mathrm{Cl}_{2}$ )

\begin{tabular}{cccccc}
\hline Entry & $1 / \mathrm{T}\left(\times 10^{-3} \mathrm{~K}^{-1}\right)$ & Run 1 & $\begin{array}{c}\ln \left(k_{\text {obs }}\right) \\
\text { Run } 2\end{array}$ & Run 3 & $\begin{array}{c}\ln \left(\text { av } k_{\text {obs }}\right) \\
( \pm \text { std deviation })\end{array}$ \\
\hline 1 & 3.29 & -5.28 & -5.06 & -5.03 & $-5.11(0.1)$ \\
2 & 3.37 & -6.08 & -6.08 & -6.09 & $-6.08(0.008)$ \\
3 & 3.45 & -7.53 & -7.50 & -7.72 & $-7.58(0.1)$ \\
4 & 3.53 & -8.84 & -8.85 & -8.82 & $-8.84(0.01)$ \\
\hline
\end{tabular}

Table s30. Conversion of temperature and $k_{\mathrm{obs}}$ for use in Arrhenius equation (in toluene- $d_{8}$ )

\begin{tabular}{cccccc}
\hline Entry & $1 / \mathrm{T}\left(\times 10^{-3} \mathrm{~K}^{-1}\right)$ & Run 1 & $\begin{array}{c}\ln \left(k_{\text {obs }}\right) \\
\text { Run } 2\end{array}$ & Run 3 & $\begin{array}{c}\ln \left(\mathrm{av} k_{\text {obs }}\right) \\
\text { ( } 1 \text { std deviation) }\end{array}$ \\
\hline 1 & 3.19 & -4.995 & -5.00 & -4.93 & $-4.98(0.03)$ \\
2 & 3.27 & -5.90 & -5.95 & -5.91 & $-5.92(0.02)$ \\
3 & 3.36 & -7.33 & -7.32 & -7.35 & $-7.33(0.01)$ \\
4 & 3.45 & -8.80 & -8.82 & -8.81 & $-8.81(0.01)$ \\
\hline
\end{tabular}

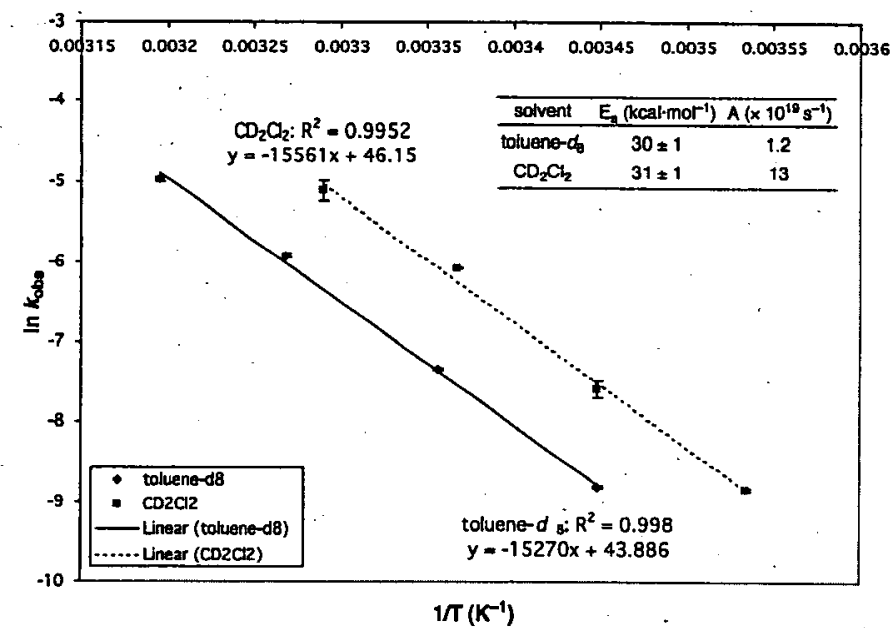

Figure s30. Linear correlation between $1 / \mathrm{T}$ and $\ln \left(k_{\mathrm{obs}}\right)^{9}$ 
(C) 2004 American Chemical Society, J. Am. Chem. Soc., Driver ja0306563 Supporting Info Page 33

Supporting Information: Tom G. Driver and K. A. Woerpel

\section{References}

(1) Pangborn, A. B.; Giardello, M. A.; Grubbs, R. H.; Rosen, R. K.; Timmers, F. J. Organometallics 1996, 15, 1518-1520.

(2) Boudjouk, P.; Black,.E.; Kumarathasan, R. Organometallics 1991, 10, 2095-2096.

(3) Boudjouk, P.; Samaraweera, U.; Sooriyakumaran, R.; Chrusciel, J.; Anderson, K. R. Angew. Chem., Int. Ed. Engl. 1988, 27, 1355-1356.

(4) Kroke, E.; Willms, S.; Weidenbruch, M.; Saak, W.; Pohl, S.; Marsmann, H. Tetrahedron Lett. 1996, 37, 3675-3678.

(5) Bardají, M.; Crespo, O.; Laguna, A.; Fischer, A. K. Inorg. Chim. Acta 2000, 304, 7-16.

(6) Becker, E. D. High Resolution NMR Theory and Chemical Applications; Academic Press, INC: San Diego, 1980, p 281-291.

(7) Bäckvall, J.-E.; Björkmann, E. E.; Pettersson, L.; Siegbahn, P.; Strich, A. J. Am. Chem. Soc. $1985,107,7408-7412$.

(8) Hansch, C.; Leo, A.; Taft, R. W. Chem. Rev. 1991, 91, 165-195.

(9) The uncertainties in the activation parameters were calculated from the error propagation formulas derived by Girolami and Binsch. See: (a) Morse, P. M.; Spencer, M. D.; Wilson, S. R.; Girolami, G. S. Organometallics 1994, 13, 1646-1655. (b) Steigel, A.; Sauer, J.; Kleier, D. A.; Binsch, G. J. Am. Chem. Soc. 1972, 94, 2770-2779.

(10) The systematic uncertainties $\delta k_{s y s}$ were estimated based on subjective judgments of the sensitivities of the NMR integration, ca. 5\% (ref. 9a). The total uncertainties $\delta k$ were calculated from $\delta k=$ $\left[\delta k_{(\text {ran })}{ }^{2}+\delta k_{(\text {(sys) }}{ }^{2}\right]^{1 / 2}$. See: Li, L.; Hung, M.; Xue, Z. J. Am. Chem. Soc. 1995, 117, 12746-12750 
(C) 2004 American Chemical Society, J. Am. Chem. Soc., Driver ja0306563 Supporting Info Page 34

Supporting Information: Tom G. Driver and K. A. Woerpel

\section{Crystallographic data}

$\mathrm{X}$-ray Data Collection, Structure Solution and Refinement for $\left[\left(\mathrm{Ph}_{3} \mathrm{P}\right)_{2} \mathrm{AgOTf}\right]_{2}$.

A colorless crystal of approximate dimensions $0.16 \times 0.34 \times 0.36 \mathrm{~mm}$ was mounted on a glass fiber and transferred to a Bruker CCD platform diffractometer. The SMART ${ }^{1}$ program package was used to determine the unit-cell parameters and for data collection ( $25 \mathrm{sec} /$ frame scan time for a sphere of diffraction data). The raw frame data was processed using $\mathrm{SAINT}^{2}$ and $\mathrm{SADABS}^{3}$ to yield the reflection data file. Subsequent calculations were carried out using the SHELXTL program. There were no systematic absences nor any diffraction symmetry other than the Friedel condition. The centrosymmetric triclinic space group $\mathrm{P} \overline{1}$ was assigned and later determined to be correct.

The structure was solved by direct methods and refined on $\mathrm{F}^{2}$ by full-matrix least-squares techniques. The analytical scattering factors ${ }^{5}$ for neutral atoms were used throughout the analysis. Hydrogen atoms were included using a riding model. The molecule was located about an inversion center. Atoms $\mathrm{C}(37), \mathrm{F}(2), \mathrm{O}(3)$ and $S(1)$ were disordered and included using multiple components with partial site-occupancy-factors (70:30 disorder). At convergence, $w R 2=0.0676$ and $\mathrm{Goof}=1.018$ for 424 variables refined against 7804 data. As a comparison for refinement on $F, R 1=0.0278$ for those 7266 data with $\mathrm{I}>2.0 \sigma(\mathrm{I})$.

References.

1. SMART Software Users Guide, Version 5.1, Bruker Analytical X-Ray Systems, Inc.; Madison, WI 1999.

2. SAINT Software Users Guide, Version 6.0, Bruker Analytical X-Ray Systems, Inc.; Madison, WI 1999.

3. Sheldrick, G. M. SADABS, Version 2.05, Bruker Analytical X-Ray Systems, Inc.; Madison, WI 2001.

4. Sheldrick, G. M. SHELXTL Version 6.12, Bruker Analytical X-Ray Systems, Inc.; Madison, WI 2001.

5. International Tables for X-Ray Crystallography 1992, Vol. C., Dordrecht: Kluwer AcademicPublishers.

Definitions:

$w R 2=\left[\Sigma\left[w\left(F_{0}^{2}-F_{c}^{2}\right)^{2}\right] / \Sigma\left[w\left(F_{o}^{2}\right)^{2}\right]^{1 / 2}\right.$

$\mathrm{R} 1=\Sigma\left\|\mathrm{F}_{\mathrm{o}} \mathrm{I}\left|\mathrm{F}_{\mathrm{c}} \| / \Sigma\right| \mathrm{F}_{\mathrm{o}} \mathrm{I}\right.$

Goof $=S=\left[\Sigma\left[w\left(F_{o}^{2}-F_{c}^{2}\right)^{2}\right] /(n-p)\right]^{1 / 2}$ where $n$ is the number of reflections and $p$ is the total number of parameters refined.

The thermal ellipsoid plot is shown at the $50 \%$ probability level. 


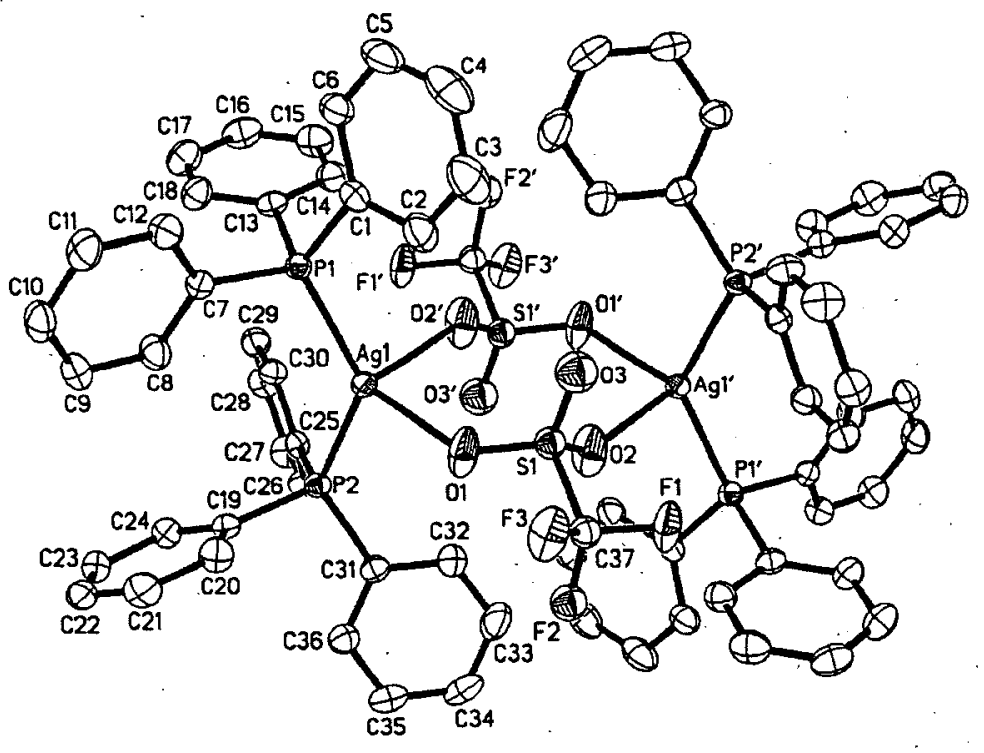

Table s35. Crystal data and structure refinement for $\left[\left(\mathrm{Ph}_{3} \mathrm{P}\right)_{2} \mathrm{AgOTf}\right]_{2}$.

Identification code

Empirical formula

Formula weight

Temperature

Wavelength

Crystal system

Space group

Unit cell dimensions

Volume

Z

Density (calculated)

Absorption coefficient

$\mathrm{F}(000)$

Crystal size

Theta range for data collection

Index ranges

Reflections collected

Independent reflections

Completeness to theta $=28.29^{\circ}$

Absorption correction

Max. and min. transmission

Refinement method

Data / restraints / parameters

Goodness-of-fit on $\mathrm{F}^{2}$.

Final $R$ indices [ $\mathrm{I}>2$ sigma(I)]

$\mathrm{R}$ indices (all data)

Largest diff. peak and hole

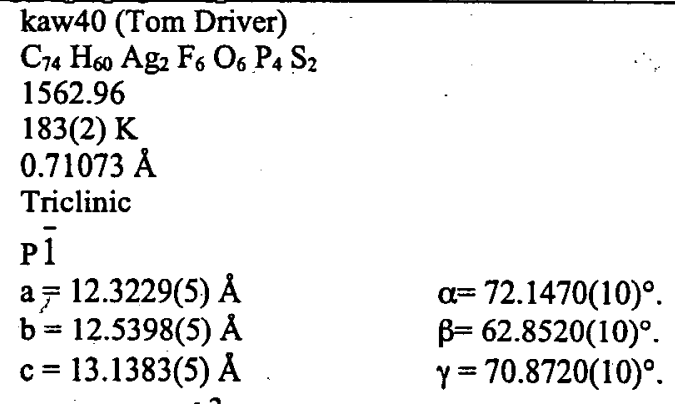

1676.76(11) $\AA^{3}$

$1.548 \mathrm{Mg} / \mathrm{m}^{3}$

$0.812 \mathrm{~mm}^{-1}$

792

$0.36 \times 0.34 \times 0.16 \mathrm{~mm}^{3}$

1.75 to $28.29^{\circ}$.

$-16 \leq h \leq 16,-16 \leq k \leq 16,-17 \leq l \leq 17$

17696

$7804[\mathrm{R}$ (int) $=0.0190]$

$93.6 \%$

Semi-empirical from equivalents

0.8811 and 0.7587 .

Full-matrix least-squares on $\mathrm{F}^{2}$

7804 / 0 / 424

1.018

$\mathrm{R} 1=0.0278, w R 2=0.0659$

$\mathrm{R} 1=0.0303, \mathrm{wR} 2=0.0676$

1.233 and -0.902 e. $\AA^{-3}$ 
Table s36. Atomic coordinates $\left(\times 10^{4}\right)$ and equivalent isotropic displacement parameters $\left(\AA^{2} \times 10^{3}\right)$ for $\left[\left(\mathrm{Ph}_{3} \mathrm{P}\right)_{2} \mathrm{AgOTf}\right]_{2}$. U(eq) is defined as one third of the trace of the orthogonalized $\mathrm{U}^{\mathrm{ij}}$ tensor.

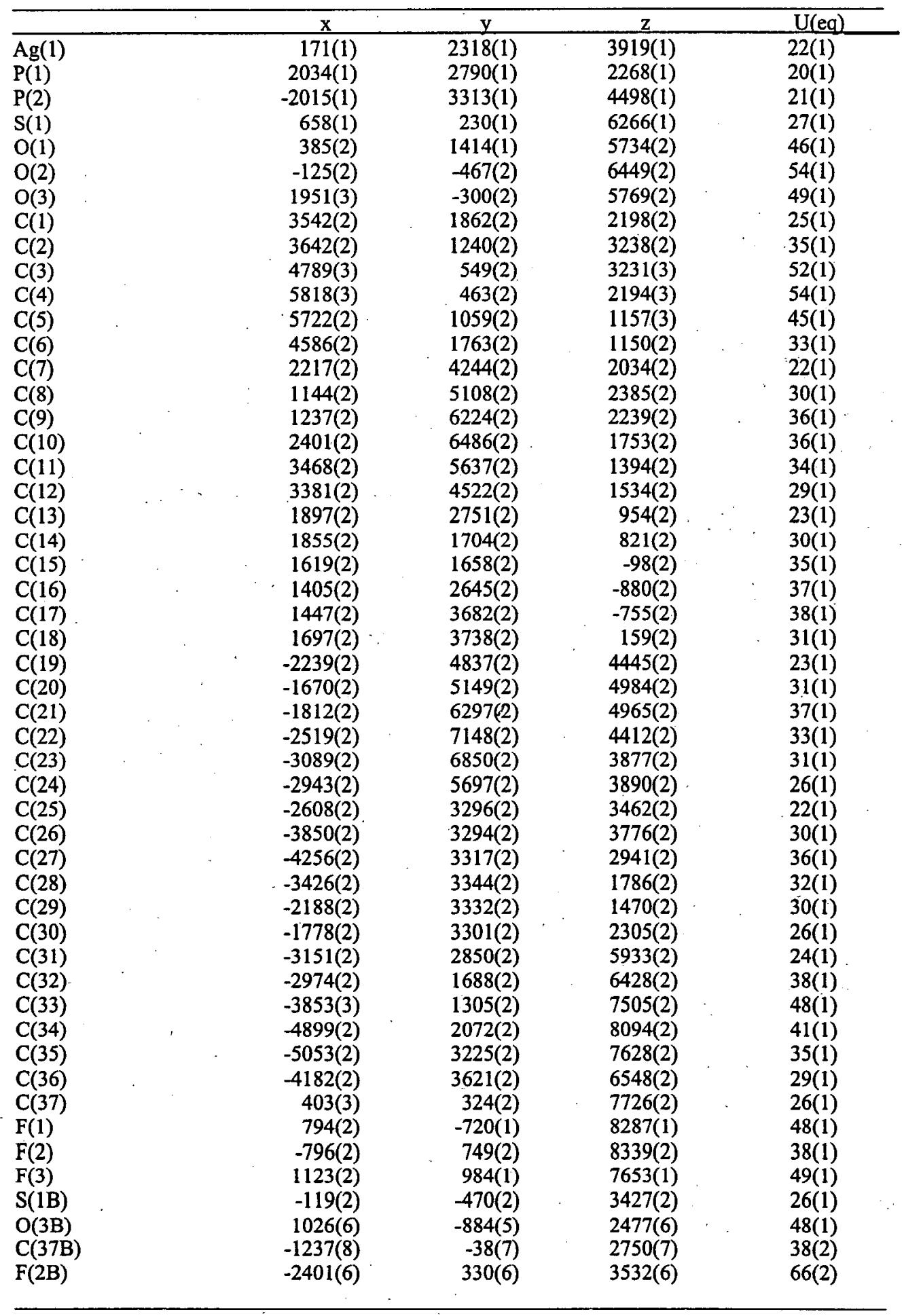


(C) 2004 American Chemical Society, J. Am. Chem. Soc., Driver ja0306563 Supporting Info Page 37

Supporting Information: Tom G. Driver and K. A. Woerpel

$s-37$

Table s37. Bond lengths $[\AA]$ and angles $\left[^{\circ}\right]$ for $\left[\left(\mathrm{Ph}_{3} \mathrm{P}\right)_{2} \mathrm{AgOTf}\right]_{2}$

\begin{tabular}{|c|c|c|c|c|c|c|c|c|c|}
\hline$\overline{A g(1)-O(1)}$ & & $2.4008(16)$ & & & & & $C(33)-C(34)$ & & $1.385(4)$ \\
\hline $\mathrm{Ag}(1)-\mathrm{P}(1)$ & & $2.4258(5)$ & & . & & & $C(34)-C(35)$ & & $1.374(4)$ \\
\hline $\operatorname{Ag}(1)-P(2)$ & & $2.4283(5)$ & & & & & $C(35)-C(36)$ & & $1.393(3)$ \\
\hline $\mathrm{Ag}(1)-\mathrm{O}(2) \# 1$ & & $2.5354(17)$ & & & & & $\mathrm{C}(37)-\mathrm{C}(37 \mathrm{~B}) \# 1$ & & $0.941(8)$ \\
\hline$P(1)-C(1)$ & & $1.818(2)$ & & & & & $C(37)-F(2)$ & & $1.333(3)$ \\
\hline$P(1)-C(13)$ & & $1.8253(19)$ & & & & & $C(37)-F(1)$ & & $1.344(3)$ \\
\hline$P(1)-C(7)$ & & $1.8257(19)$ & & & & & $C(37)-F(3)$ & & $1.354(3)$ \\
\hline$P(2)-C(31)$ & & $1.818(2)$ & & & & & $\mathrm{C}(37)-\mathrm{S}(1 \mathrm{~B}) \# 1$ & & $1.650(3)$ \\
\hline$P(2)-C(25)$ & . & $1.8223(19)$ & & & & & $\mathrm{C}(37)-\mathrm{O}(3 \mathrm{~B}) \# 1$ & & $1.781(7)$ \\
\hline $\mathrm{P}(2)-\mathrm{C}(19)$ & & $1.824(2)$ & & & & & $F(1)-C(37 B) \# 1$ & & $1.388(8)$ \\
\hline$S(1)-S(1 B) \# 1$ & & $0.6268(17)$ & & & & & $\mathrm{F}(2)-\mathrm{O}(3 \mathrm{~B}) \# 1$ & . & $1.181(6)$ \\
\hline$S(1)-O(2)$ & & $1.4021(19)$ & & & & & $F(2)-S(1 B) \# 1$ & & $2.151(3)$ \\
\hline $\mathrm{S}(1)-\mathrm{O}(3)$ & & $1.424(3)$ & & & & & $F(3)-C(37 B) \# 1$ & & $1.383(8)$ \\
\hline$S(1)-O(1)$ & & $1.4337(18)$ & & & & & $S(1 B)-S(1) \# 1$ & & $0.6268(17)$ \\
\hline$S(1)-C(37 B) \# 1$ & & $1.665(8)$ & & & & & $S(1 B)-O(1) \# 1$ & & $1.359(2)$ \\
\hline$S(1)-C(37)$ & & $1.832(3)$ & & & & & $S(1 B)-O(2) \# 1$ & & $1.375(2)$ \\
\hline $\mathrm{S}(1)-\mathrm{O}(3 \mathrm{~B}) \# 1$ & & $2.072(6)$ & & & & & $S(1 B)-O(3 B)$ & & $1.459(7)$ \\
\hline $\mathrm{S}(1)-\mathrm{F}(2 \mathrm{~B}) \# 1$ & & $2.143(7)$ & & & & & $S(1 B)-C(37) \# 1$ & & $1.650(3)$ \\
\hline$O(1)-S(1 B) \# 1$ & & $1.359(2)$ & & & & & $S(1 B)-C(37 B)$ & & $1.820(8)$ \\
\hline$O(2)-S(1 B) \# 1$ & & $1.375(2)$ & & & & & $S(1 B)-O(3) \# 1$ & & $2.040(3)$ \\
\hline$O(2)-A g(1) \# 1$ & & $2.5354(17)$ & & & & . & $S(1 B)-F(2) \# 1$ & - & $2.151(3)$ \\
\hline$O(3)-F(2 B) \# 1$ & & $1.259(7)$ & & & & & $\mathrm{O}(3 \mathrm{~B})-\mathrm{F}(2) \# 1$ & - & $1.181(6)$ \\
\hline $\mathrm{O}(3)-\mathrm{C}(37 \mathrm{~B}) \# 1$ & & $1.854(9)$ & & & & . & $\mathrm{O}(3 \mathrm{~B})-\mathrm{C}(37) \# 1$ & & $1.781(7)$ \\
\hline $\mathrm{O}(3)-\mathrm{S}(1 \mathrm{~B}) \# 1$ & . & $2.040(3)$ & & & & & $O(3 B)-S(1) \# 1$ & $\therefore$ & $2.072(6)$ \\
\hline$C(1)-C(2)$ & & $1.389(3)$ & & & & & $\mathrm{C}(37 \mathrm{~B})-\mathrm{C}(37) \# 1$ & & $0.941(8)$ \\
\hline$C(1)-C(6)$ & & $1.396(3)$ & & & & & $\mathrm{C}(37 \mathrm{~B})-\mathrm{F}(2 \mathrm{~B})$ & & $1.356(10)$ \\
\hline$C(2)-C(3)$ & & $1.392(3)$ & r. & & & & $\mathrm{C}(37 \mathrm{~B})-\mathrm{F}(3) \# 1$ & & $1.383(8)$ \\
\hline$C(3)-C(4)$ & & $1.378(4)$ & & & & & $\mathrm{C}(37 \mathrm{~B})-\mathrm{F}(1) \# 1$ & . & $1.388(8)$ \\
\hline$C(4)-C(5)$ & & $1.376(4)$ & & & & & $C(37 B)-S(1) \# 1$ & & $1.665(8)$ \\
\hline$C(5)-C(6)$ & & $1.391(3)$ & & & & & $\mathrm{C}(37 \mathrm{~B})-\mathrm{O}(3) \# 1$ & & $1.854(9)$ \\
\hline $\mathrm{C}(7)-\mathrm{C}(12)$ & & $1.392(3)$ & & & & & $F(2 B)-O(3) \# 1$ & & $1.259(7)$ \\
\hline$C(7)-C(8)$ & & $1.395(3)$ & & & & & $F(2 B)-S(1) \# 1$ & & $2.143(6)$ \\
\hline $\mathrm{C}(8)-\mathrm{C}(9)$ & $\cdot$ & $1.389(3)$ & & $t$ & & & $\mathrm{O}(1)-\mathrm{Ag}(1)-\mathrm{P}(1)$ & & $116.71(5)$ \\
\hline$C(9)-C(10)$ & 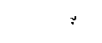 & $1.386(3)$ & & & & & $\mathrm{O}(1)-\mathrm{Ag}(1)-\mathrm{P}(2)$ & & $103.83(5)$ \\
\hline$C(10)-C(11)$ & & $1.381(3)$ & & & & & $\mathrm{P}(1)-\mathrm{Ag}(1)-\mathrm{P}(2)$ & & $131.559(17)$ \\
\hline $\mathrm{C}(11)-\mathrm{C}(12)$ & & $1.386(3)$ & & & & & $\mathrm{O}(1)-\mathrm{Ag}(1)-\mathrm{O}(2) \# 1$ & & $93.43(6)$ \\
\hline$C(13)-C(18)$ & & $1.388(3)$ & - & & & & $\mathrm{P}(1)-\mathrm{Ag}(1)-\mathrm{O}(2) \# 1$ & & $101.31(5)$ \\
\hline$C(13)-C(14)$ & & $1.396(3)$ & & & & & $\mathrm{P}(2)-\mathrm{Ag}(1)-\mathrm{O}(2) \# 1$ & & $101.58(5)$ \\
\hline$C(14)-C(15)$ & & $1.386(3)$ & & & & & $\mathrm{C}(1)-\mathrm{P}(1)-\mathrm{C}(13)$ & & $105.75(9)$ \\
\hline$C(15)-C(16)$ & & $1.383(4)$ & & & & & $\mathrm{C}(1)-\mathrm{P}(1)-\mathrm{C}(7)$ & & $105.04(9)$ \\
\hline$C(16)-C(17)$ & & $1.379(3)$ & & & & & $C(13)-P(1)-C(7)$ & & 104.19(9) \\
\hline$C(17)-C(18)$ & & $1.395(3)$ & & & & & $\mathrm{C}(1)-\mathrm{P}(1)-\mathrm{Ag}(1)$ & & $118.19(7)$ \\
\hline$C(19)-C(24)$ & & $1.389(3)$ & & & & & $\mathrm{C}(13)-\mathrm{P}(1)-\mathrm{Ag}(1)$ & & $107.57(6)$ \\
\hline$C(19)-C(20)$ & & $1.395(3)$ & & . & & & $\mathrm{C}(7)-\mathrm{P}(1)-\mathrm{Ag}(1)$ & & $114.91(6)$ \\
\hline$C(20)-C(21)$ & & $1.386(3)$ & & & & & $C(31)-P(2)-C(25)$ & & $105.95(9)$ \\
\hline$C(21)-C(22)$ & & $1.387(3)$ & & & & & $\mathrm{C}(31)-\mathrm{P}(2)-\mathrm{C}(19)$ & & $103.10(9)$ \\
\hline$C(22)-C(23)$ & & $1.381(3)$ & & & & & $C(25)-P(2)-C(19)$ & & 103.99(9) \\
\hline$C(23)-C(24)$ & & $1.393(3)$ & & & & & $\mathrm{C}(31)-\mathrm{P}(2)-\mathrm{Ag}(1)$ & & $119.96(7)$ \\
\hline$C(25)-C(30)$ & & $1.391(3)$ & & & & & $\mathrm{C}(25)-\mathrm{P}(2)-\mathrm{Ag}(1)$ & & $110.10(6)$ \\
\hline$C(25)-C(26)$ & & $1.392(3)$ & & & & & $\mathrm{C}(19)-\mathrm{P}(2)-\mathrm{Ag}(1)$ & & $112.35(6)$ \\
\hline$C(26)-C(27)$ & & $1.388(3)$ & & & & & $S(1 B) \# 1-S(1)-O(2)$ & & $74.5(2)$ \\
\hline$C(27)-C(28)$ & & $1.388(3)$ & & & & & $S(1 B) \# 1-S(1)-O(3)$ & & 167.3(2) \\
\hline$C(28)-C(29)$ & & $1.381(3)$ & & & & & $O(2)-S(1)-O(3)$ & & $112.69(15)$ \\
\hline$C(29)-C(30)$ & & $1.389(3)$ & & & & & $S(1 B) \# 1-S(1)-O(1)$ & & $70.46(19)$ \\
\hline$C(31)-C(32)$ & & $1.392(3)$ & & & . & & $O(2)-S(1)-O(1)$ & & $118.04(12)$ \\
\hline$C(31)-C(36)$ & & $1.392(3)$ & & & & & $O(3)-S(1)-O(1)$ & & $112.50(15)$ \\
\hline$C(32)-C(33)$ & & $1.390(3)$ & & & & & $S(1 B) \# 1-S(1)-C(37 B)$ & $\# 1$ & $94.1(3)$ \\
\hline
\end{tabular}


(C) 2004 American Chemical Society, J. Am. Chem. Soc., Driver ja0306563 Supporting Info Page 38

Supporting Information: Tom G. Driver and K. A. Woerpel

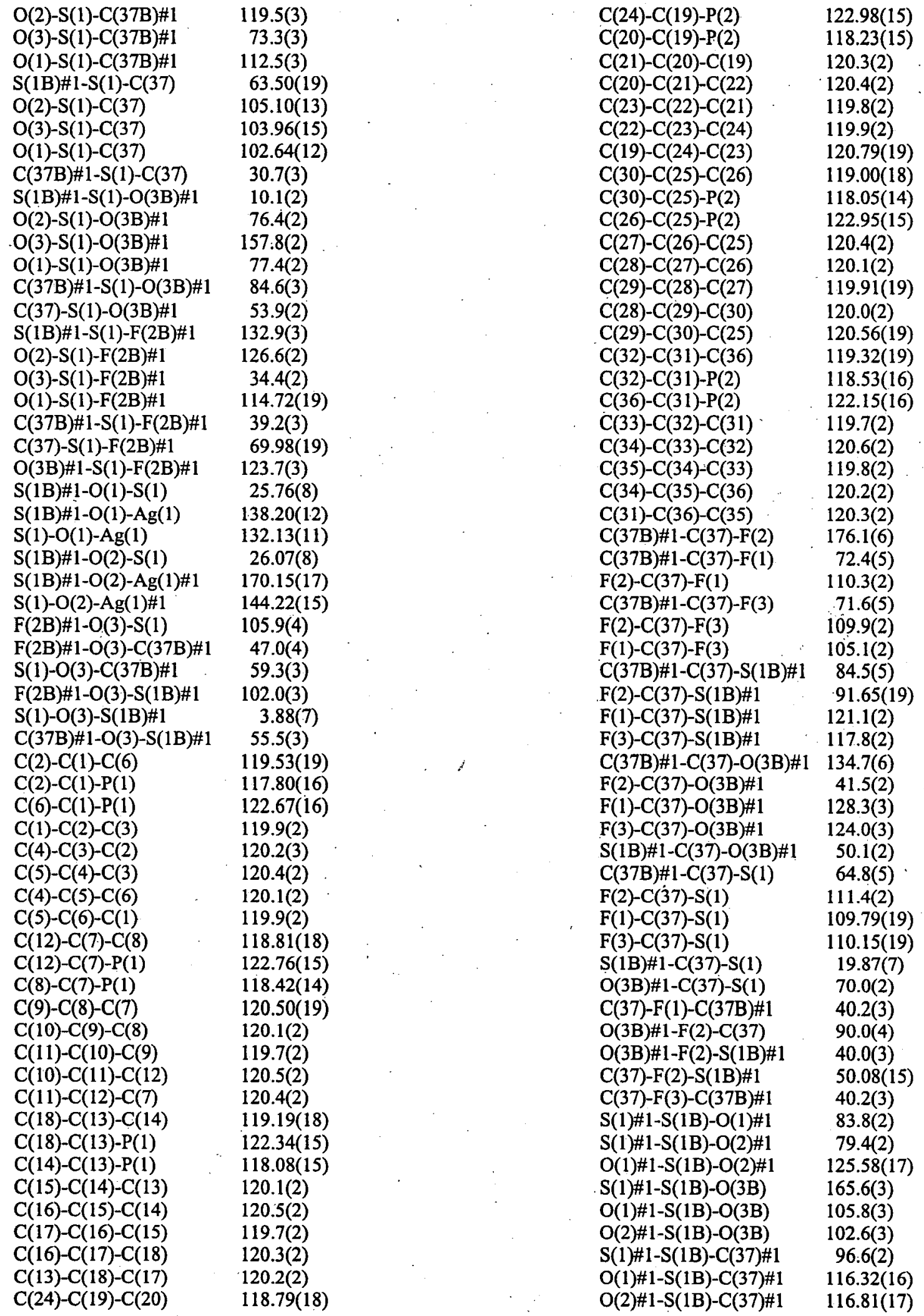


(C) 2004 American Chemical Society, J. Am. Chem. Soc., Driver ja0306563 Supporting Info Page 39

Supporting Information: Tom G. Driver and K. A. Woerpel

$\begin{array}{lc}\mathrm{O}(3 \mathrm{~B})-\mathrm{S}(1 \mathrm{~B})-\mathrm{C}(37) \# 1 & 69.6(3) \\ \mathrm{S}(1) \# 1-\mathrm{S}(1 \mathrm{~B})-\mathrm{C}(37 \mathrm{~B}) & 65.8(3) \\ \mathrm{O}(1) \# 1-\mathrm{S}(1 \mathrm{~B})-\mathrm{C}(37 \mathrm{~B}) & 107.6(3) \\ \mathrm{O}(2) \# 1-\mathrm{S}(1 \mathrm{~B})-\mathrm{C}(37 \mathrm{~B}) & 111.5(3) \\ \mathrm{O}(3 \mathrm{~B})-\mathrm{S}(1 \mathrm{~B})-\mathrm{C}(37 \mathrm{~B}) & 100.5(4) \\ \mathrm{C}(37) \# 1-\mathrm{S}(1 \mathrm{~B})-\mathrm{C}(37 \mathrm{~B}) & 31.0(3) \\ \mathrm{S}(1) \# 1-\mathrm{S}(1 \mathrm{~B})-\mathrm{O}(3) \# 1 & 8.84(16) \\ \mathrm{O}(1) \# 1-\mathrm{S}(1 \mathrm{~B})-\mathrm{O}(3) \# 1 & 86.24(15) \\ \mathrm{O}(2) \# 1-\mathrm{S}(1 \mathrm{~B})-\mathrm{O}(3) \# 1 & 84.71(16) \\ \mathrm{O}(3 \mathrm{~B})-\mathrm{S}(1 \mathrm{~B})-\mathrm{O}(3) \# 1 & 157.3(3) \\ \mathrm{C}(37) \# 1-\mathrm{S}(1 \mathrm{~B})-\mathrm{O}(3) \# 1 & 87.92(15) \\ \mathrm{C}(37 \mathrm{~B})-\mathrm{S}(1 \mathrm{~B})-\mathrm{O}(3) \# 1 & 57.1(3) \\ \mathrm{S}(1) \# 1-\mathrm{S}(1 \mathrm{~B})-\mathrm{F}(2) \# 1 & 134.7(2) \\ \mathrm{O}(1) \# 1-\mathrm{S}(1 \mathrm{~B})-\mathrm{F}(2) \# 1 & 115.84(14) \\ \mathrm{O}(2) \# 1-\mathrm{S}(1 \mathrm{~B})-\mathrm{F}(2) \# 1 & 112.60(14) \\ \mathrm{O}(3 \mathrm{~B})-\mathrm{S}(1 \mathrm{~B})-\mathrm{F}(2) \# 1 & 31.3(3) \\ \mathrm{C}(37) \# 1-\mathrm{S}(1 \mathrm{~B})-\mathrm{F}(2) \# 1 & 38.27(12) \\ \mathrm{C}(37 \mathrm{~B})-\mathrm{S}(1 \mathrm{~B})-\mathrm{F}(2) \# 1 & 69.2(3) \\ \mathrm{O}(3) \# 1-\mathrm{S}(1 \mathrm{~B})-\mathrm{F}(2) \# 1 & 126.09(12) \\ \mathrm{F}(2) \# 1-\mathrm{O}(3 \mathrm{~B})-\mathrm{S}(1 \mathrm{~B}) & 108.7(5) \\ \mathrm{F}(2) \# 1-\mathrm{O}(3 \mathrm{~B})-\mathrm{C}(37) \# 1 & 48.4(3) \\ \mathrm{S}(1 \mathrm{~B})-\mathrm{O}(3 \mathrm{~B})-\mathrm{C}(37) \# 1 & 60.3(3) \\ \mathrm{F}(2) \# 1-\mathrm{O}(3 \mathrm{~B})-\mathrm{S}(1) \# 1 & 104.5(4) \\ \mathrm{S}(1 \mathrm{~B})-\mathrm{O}(3 \mathrm{~B})-\mathrm{S}(1) \# 1 & 4.32(10) \\ \mathrm{C}(37) \# 1-\mathrm{O}(3 \mathrm{~B})-\mathrm{S}(1) \# 1 & 56.2(2) \\ \end{array}$

$\begin{array}{lr}\text { C(37)\#1-C(37B)-F(2B) } & 174.1(9) \\ \text { C(37)\#1-C(37B)-F(3)\#1 } & 68.3(5) \\ \text { F(2B)-C(37B)-F(3)\#1 } & 113.5(6) \\ \text { C(37)\#1-C(37B)-F(1)\#1 } & 67.4(5) \\ \text { F(2B)-C(37B)-F(1)\#1 } & 117.0(7) \\ \text { F(3)\#1-C(37B)-F(1)\#1 } & 101.3(5) \\ \text { C(37)\#1-C(37B)-S(1)\#1 } & 84.5(6) \\ \text { F(2B)-C(37B)-S(1)\#1 } & 89.8(5) \\ \text { F(3)\#1-C(37B)-S(1)\#1 } & 118.7(5) \\ \text { F(1)\#1-C(37B)-S(1)\#1 } & 117.5(5) \\ \text { C(37)\#1-C(37B)-S(1B) } & 64.5(5) \\ \text { F(2B)-C(37B)-S(1B) } & 109.7(6) \\ \text { F(3)\#1-C(37B)-S(1B) } & 106.3(5) \\ \text { F(1)\#1-C(37B)-S(1B) } & 108.3(5) \\ \text { S(1)\#1-C(37B)-S(1B) } & 20.09(11) \\ \text { C(37)\#1-C(37B)-O(3)\#1 } & 131.7(7) \\ \text { F(2B)-C(37B)-O(3)\#1 } & 42.8(4) \\ \text { F(3)\#1-C(37B)-O(3)\#1 } & 132.5(6) \\ \text { F(1)\#1-C(37B)-O(3)\#1 } & 125.8(5) \\ \text { S(1)\#1-C(37B)-O(3)\#1 } & 47.4(2) \\ \text { S(1B)-C(37B)-O(3)\#1 } & 67.4(3) \\ \text { O(3)\#1-F(2B)-C(37B) } & 90.2(5) \\ \text { O(3)\#1-F(2B)-S(1)\#1 } & 39.7(2) \\ \text { C(37B)-F(2B)-S(1)\#1 } & 51.0(4) \\ & \end{array}$

Symmetry transformations used to generate equivalent atoms: \#1 -x,-y,-z+1 
(C) 2004 American Chemical Society, J. Am. Chem. Soc., Driver ja0306563 Supporting Info Page 40

Supporting Information: Tom G. Driver and K. A. Woerpel

Table s38. Anisotropic displacement parameters $\left(\AA^{2} \times 10^{3}\right)$ for $\left[\left(\mathrm{Ph}_{3} \mathrm{P}\right)_{2} \mathrm{AgOTf}\right]_{2}$. The anisotropic displacement factor exponent takes the form: $-2 \pi^{2}\left[\mathrm{~h}^{2} \mathrm{a}^{* 2} \mathrm{U}^{11}+\ldots+2 \mathrm{~h} \mathrm{k} \mathrm{a}^{*} \mathrm{~b}^{*} \mathrm{U}^{12}\right]$

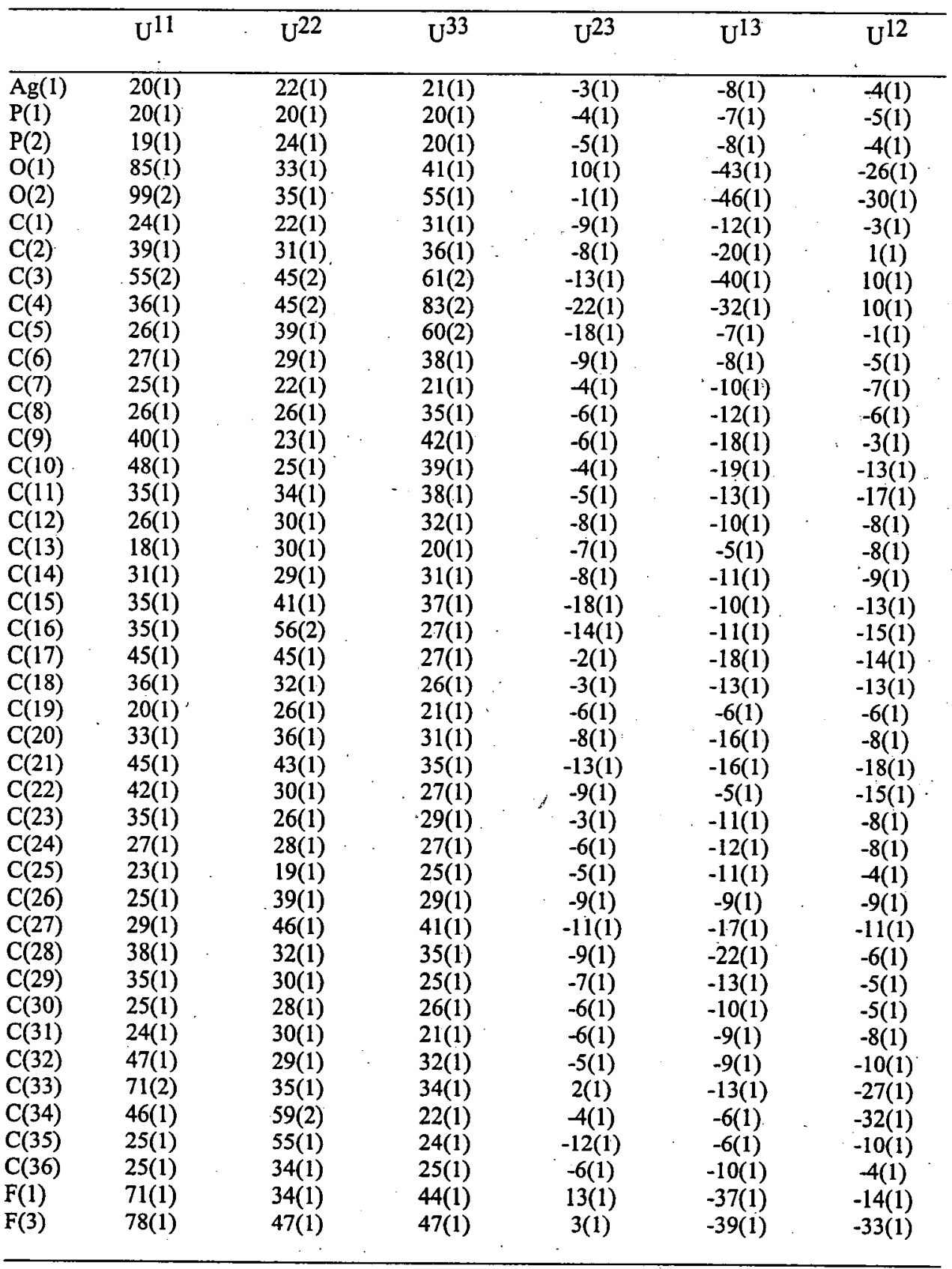

